LAILA ANDREIA RODRIGUES BESERRA

Ocorrência e caracterização de rotavírus em frangos de corte, poedeiras e matrizes de criações comerciais brasileiras 


\section{Ocorrência e caracterização de rotavírus em frangos de corte, poedeiras e matrizes de criações comerciais brasileiras}

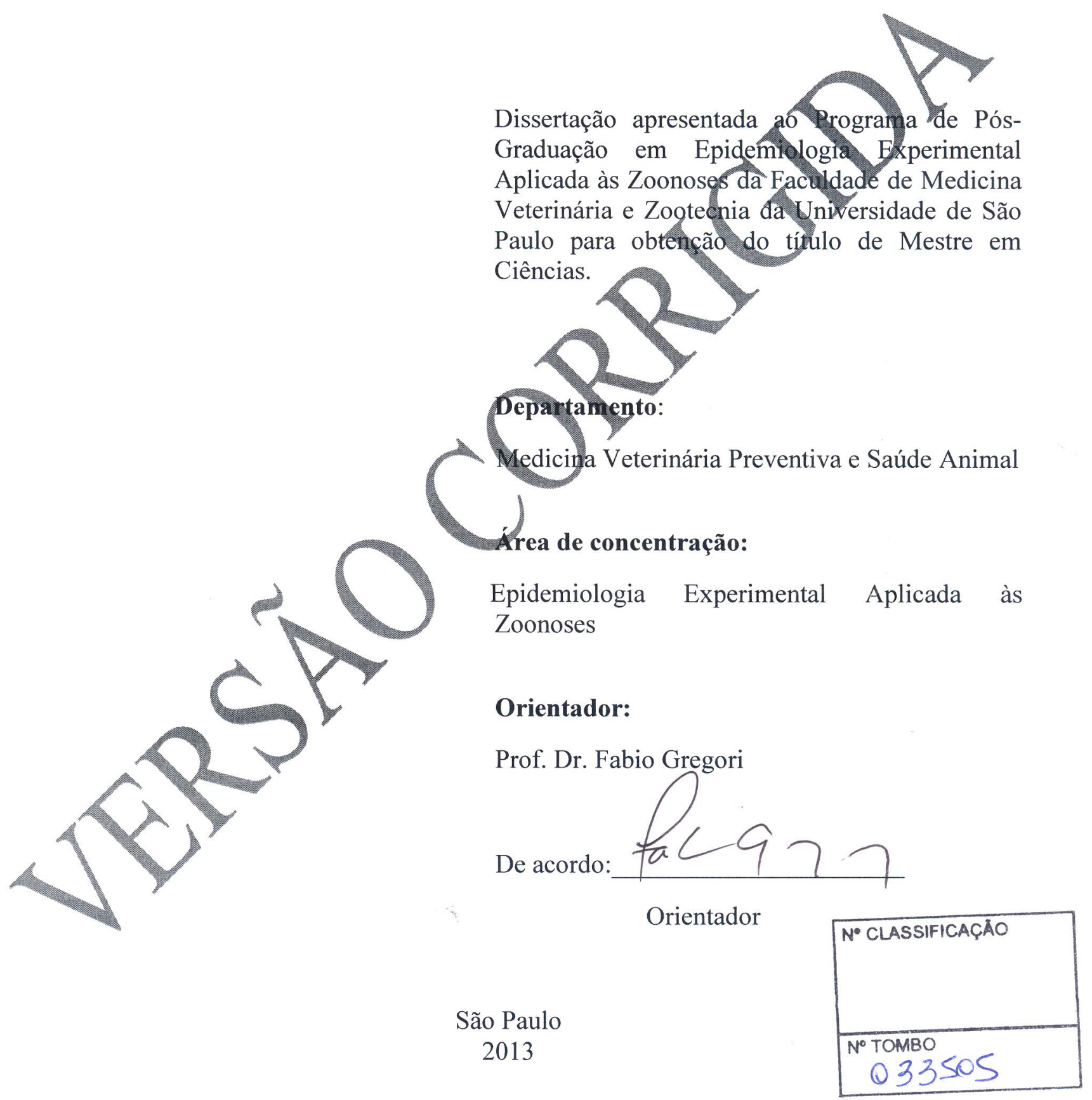

Obs: A versão original se encontra disponível na Biblioteca da FMVZ/USP 
Autorizo a reprodução parcial ou total desta obra, para fins acadêmicos, desde que citada a fonte.

\section{DADOS INTERNACIONAIS DE CATALOGAÇÃO-NA-PUBLICAÇÃO}

(Biblioteca Virginie Buff D’Ápice da Faculdade de Medicina Veterinária e Zootecnia da Universidade de São Paulo)

Beserra, Laila Andréia Rodrigues

Ocorrência e caracterização de rotavírus em frangos de corte, poedeiras e matrizes de

FMVZ criações comerciais brasileiras / Laila Andréia Rodrigues Beserra. -- 2013

119 f. : il.

Dissertação (Mestrado) - Universidade de São Paulo. Faculdade de Medicina Veterinária e Zootecnia. Departamento de Medicina Veterinária Preventiva e Saúde Animal, São Paulo, 2013.

Programa de Pós-Graduação: Epidemiologia Experimental Aplicada às Zoonoses.

Área de concentração: Epidemiologia Experimental Aplicada às Zoonoses.

Orientador: Prof. Dr. Fábio Gregori.

1. Rotavírus. 2. Aves. 3. Avicultura. 4. PCR. 5. Medicina veterinária preventiva. I. Título. 


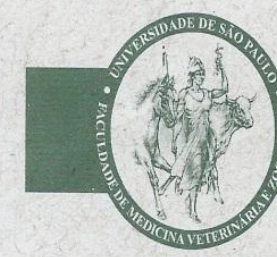

UNIVERSIDADE DE SÃO PAULO

FACULDADE DE MEDICINA VETERINÁRIA E ZOOTECNIA

Comissão de Ética no uso de animais

\section{CERTIFICADO}

Certificamos que o Projeto intitulado "Ocorrência e caracterização genotípica de Rotavírus Grupo A em frangos de corte, poedeiras e matrizes em criações comerciais brasileiras", protocolado sob o n ${ }^{\circ}$ 2236/2011, utilizando 250 (duzentos e cinquenta) galinhas e frangos, sob a responsabilidade do(a) Prof. Dr. Fabio Gregori, está de acordo com os princípios éticos de experimentação animal da "Comissão de Ética no uso de animais" da Faculdade de Medicina Veterinária e Zootecnia da Universidade de São Paulo e foi aprovado em reunião de $22 / 6 / 2011$.

We certify that the Research "Occurrence and genotypic characterization of group A Rotavirus in broilers, layers, and broilers breeders from Brazilian commercial poultry farms", protocol number 2236/2011, utilizing 250 (two hundred and fifty) chickens and broilers, under the responsibility Prof. Dr. Fabio Gregori, agree with Ethical Principles in Animal Research adopted by. "Ethic Committee in the use of animals" of the School of Veterinary Medicine and Animal Science of University of São Paulo and was approved in the meeting of day $06 / 22 / 2011$.

São Paulo, 27 de junho de 2011.

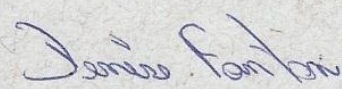

Profa. Dra. Denise Tabacchi Fantoni

Presidente 


\section{FOLHA DE AVALIAÇÃO}

Autor: BESERRA, Laila Andreia Rodrigues

Título: Ocorrência e caracterização de rotavirus em frango de corte, poedeiras e matrizes de criações comerciais brasileiras.

Dissertação apresentada ao Programa de Pós-

Graduação em Epidemiologia Experimental Aplicada às Zoonoses da Faculdade de Medicina Veterinária e Zootecnia da Universidade de São Paulo para obtenção do título de Mestre em Ciências

Data:

\section{Banca Examinadora}

Prof. Dr.

Instituição: Julgamento:

Prof. Dr.

Instituição: Julgamento:

Prof. Dr.

Instituição: Julgamento: 


\section{DEDICATÓRIA}

Aos meus pais, João e Elânia, pelo amor e confiança

À minha irmã, Louanne, por ser minha mãe, irmã, amiga

À família Sobral 


\section{AGRADECIMENTOS}

A Deus pela força de vontade e por não me deixar desanimar nunca.

Aos meus pais, simplesmente a razão da minha vida.

Ao meu orientador, Fabio Gregori, pela oportunidade, aprendizado e confiança no meu trabalho.

À minha irmã Louanne por ser esse exemplo de força, alegria e vontade de viver.

Ao Rafael pela pessoa maravilhosa que é.

Ao nosso presente de Deus, Rafael Isaac, que sem saber veio preencher um vazio e renovar o amor e a união da nossa família.

À minha família Sobral por me ensinar a cada encontro a dar valor às coisas simples da vida. Amo infinitamente.

Ao Davi Sobral pelo companheirismo, cuidado e carinho, enfim, por todos os momentos.

Ao professor Paulo Eduardo Brandão.

Aos demais professores do VPS.

À Sheila, pelo apoio técnico.

À Bruna Barbosa, Nara Thiers e Juliana Martins, pelas experiências compartilhadas e amizade.

Aos meus queridos Ruanna, Juliana, Nayanne, Thalita, Evanielle, Camila, Evaldo e Bruno.

Aos demais colegas pós-graduandos e funcionários do VPS.

À Capes e Fapesp pelo apoio financeiro. 


\section{RESUMO}

BESERRA, L.A.R. Ocorrência e caracterização de rotavírus em frangos de corte, poedeiras e matrizes de criações comerciais brasileiras. [Occurrence and characterization of rotavirus in broilers, layers and broiler breeders from Brazilian poultry farms]. 2013; $119 \mathrm{f}$. Dissertação (Mestrado em Ciências) - Faculdade de Medicina Veterinária e Zootecnia, Universidade de São Paulo, São Paulo, 2013.

Os rotavírus estão entre os principais causadores de diarreia em humanos e animais, inclusive em mamíferos e aves. Os sintomas da doença geralmente incluem diarreia e depressão, aumento da mortalidade, e "runting and stunting syndrome", caracterizado principalmente por perda de peso, também tem sido atribuído a infecções por rotavírus em aves. O capsídeo externo da partícula viral é formado pelas proteínas estruturais VP4 e VP7 que possuem antígenos de neutralização baseados nos quais os rotavírus são classificados em genotipos $\mathrm{P}$ e G, respectivamente. O capsídeo intermediário é formado pela VP6 que define os grupos de rotavírus de A-G de acordo com a reatividade de anticorpos ou sequenciamento nucleotídico desta proteína. A proteína não estrutural NSP5 está envolvida no processo de replicação viral, sendo essencial para a formação dos viroplasmas. Este estudo teve o objetivo de pesquisar a frequência de ocorrência de rotavírus dos grupos A e D, em amostras fecais de aves de diferentes criações comerciais brasileiras, seguida da caracterização dos genotipos P e G, dos rotavírus do grupo A, através de sequenciamento nucleotídico. Para isso, 111 pools de amostras fecais foram processados através das técnicas de ELISA, PAGE e RT-PCR (NSP5), resultando em $43(38,73 \%)$ amostras positivas pelas três técnicas. Definiram-se os genotipos G5, G8 e G11 através de RT-PCR (VP7) e o genotipo G19 após reação de RT-PCR seguida de sequenciamento nucleotídico. Definiu-se ainda o genotipo $\mathrm{P}[31]$ a partir do sequenciamento de amostras positivas por RT-PCR (VP4). Das 111 amostras processadas por RT-PCR visando o gene codificador da VP6, obtiveram-se 4 sequências que confirmaram tratar-se de rotavírus do grupo D. Os genotipos G5, G8 e G11 estão relacionados a surtos em bovinos e suínos, enquanto que os genotipos G19 e P[31] estão descritos em aves. Conclui-se que os rotavírus encontram-se amplamente disseminados nas criações comerciais brasileiras devido à elevada frequência da ocorrência e que existe a possibilidade de transmissão interespécie.

Palavras-chave: Rotavírus. Aves. Avicultura. PCR. Medicina Veterinária Preventiva. 


\begin{abstract}
BESERRA, L.A.R.. Occurrence and characterization of rotavirus in broilers, layers and broiler breeders from Brazilian poultry farms [Ocorrência e caracterização de rotavírus em frangos de corte, poedeiras e matrizes de criações comerciais brasileiras]. 2013; 119f. Dissertação (Mestrado em Ciências) - Faculdade de Medicina Veterinária e Zootecnia, Universidade de São Paulo, São Paulo, 2013.
\end{abstract}

Rotavirus are a major cause of diarrhea in humans and animals, including several mammalian and avian species. The symptoms of the disease generally include diarrhea and depression, increased mortality and the chronic runting and stunting syndrome mainly characterized by weight loss have also been linked to rotavirus infections of birds. The outer layer of the virus particle is formed by VP4 and VP7 proteins, which possess neutralization antigens. Based on VP7 and VP4 the rotavirus are classified into genotypes G and P respectively. The intermediate layer consists of VP6 which defines the rotavirus groups. Based on the antibody reactivity and sequence identity of VP6, seven rotavirus groups (A to E) have been defined. The NSP5 are involved in viral replication and they are essential for the formation of viroplasm. Here we report the occurrence of group A and D rotavirus in feces of broilers, layers and broiler breeders from Brazilian poultry farms. A total of 111 pools of intestinal contents were processed in this study, using a ELISA, PAGE and RT-PCR (NSP5) techniques. Out of 111 pools of fecal samples tested, 43 showed positive results $(38.73 \%)$ for rotavirus. Were typed the G5, G8 e G11 genotypes using the RT-PCR (VP7) and the G19 genotype using a RT-PCR followed by nucleotide sequencing reaction of the amplicons. Was defined the P[31] genotype using the RT-PCR (VP4) technique followed by nucleotide sequencing reaction. Out of 111 pools of fecal samples tested by RT-PCR (VP6), 4 showed positive results for rotavirus of group D. The G5, G8 and G11 are typical bovine and porcine rotavirus genotypes, whereas the G19 and P[31] genotypes are found in birds. As a conclusion, rotavirus is widely spread in commercial Brazilian poultry farms due to the high frequency of occurrence and there is the possibility of interspecies transmission.

Keywords: Rotavirus. Avian. Aviculture. PCR. Preventive Veterinary Medicine. 


\section{LISTA DE FIGURAS}

Figura 1- Sequência de atividades realizadas visando a ocorrência e caracterização de amostras de rotavírus aviário.

Figura 2- Árvore filogenética construída com o método de neighbor-joining através do modelo de substituição maximum composite likelihood (Software Mega v. 5.2) para a região parcial do gene codificador da proteína VP7 dos rotavírus. As amostras apresentam a identificação "accession number"/ hospedeiro / amostra / genotipo VP7. Os números próximos a cada nó representam os valores de 1000 repetições de bootstrap, tendo sido demonstrados apenas aqueles superiores a $70 \%$. A escala representa o número de substituições/sítio. Os triângulos representam as sequências definidas no presente estudo - São Paulo- 2013.

Figura 3- Árvore filogenética construída com o método de neighbor-joining através do modelo de substituição maximum composite likelihood (Software Mega v. 5.2) para a região parcial do gene codificador da proteína VP4 dos rotavírus. As amostras apresentam a identificação "accession number"/ hospedeiro / amostra / genotipo VP7. Os números próximos a cada nó representam os valores de 1000 repetições de bootstrap, tendo sido demonstrados apenas aqueles superiores a $70 \%$. A escala representa o número de substituições/sítio. Os triângulos representam as sequências definidas no presente estudo - São Paulo - 2013.

Figura 4- Árvore genealógica referente ao fragmento parcial dos nucleotídeos codificadores da proteína VP6 dos rotavírus do grupo D detectados no presente estudo juntamente com as sequências representativas dos demais grupos definidos recuperados do GenBank. Os números próximos a cada nó representam os valores de "bootstrap" (1000 repetições) e a escala representa o número de substituições/sítio. Os triângulos representam as sequências definidas no presente estudo - São Paulo - 2013 .66

Figura 5- Alinhamento dos fragmentos parciais do gene codificador da VP7 de rotavírus do grupo A em aves gerados no presente estudo - São Paulo - 2013 
Figura 6- Alinhamento das sequências traduzidas para aminoácidos do gene codificador da VP7 de rotavírus do grupo A em aves geradas no presente estudo. O quadro em preto representa parte do domínio hidrofóbico da proteína - São Paulo - 2013.......69

Figura 7- Alinhamento dos fragmentos parciais do gene codificador da VP4 de rotavírus do grupo A em aves gerados no presente estudo - São Paulo - 2013............................70

Figura 8- Alinhamento das sequências traduzidas para aminoácidos do gene codificador da VP4 de rotavírus do grupo A em aves geradas no presente estudo. As setas em preto indicam dois sítios de clivagem proteolítica - São Paulo - 2013.............................72

Figura 9- Alinhamento dos fragmentos parciais do gene codificador da VP6 de rotavírus do grupo D em aves gerados no presente estudo - São Paulo - 2013...........................73

Figura 10- Alinhamento das sequências traduzidas para aminoácidos do gene codificador da VP6 de rotavírus do grupo D em aves geradas no presente estudo. As setas em preto indicam os resíduos de aminoácidos hidrofóbicos - São Paulo - 2013......76 


\section{LISTA DE QUADROS}

Quadro 1- Primers, sequências, posições no genoma, comprimento do produto, e temperatura de Melting (Tm) do par de primers visando o gene codificador da VP7 de rotavírus do grupo A em aves desenhados durante o estudo. .45

Quadro 2- Sequências de VP7 de rotavírus do grupo A, recuperadas do GenBank, utilizadas para a reconstrução da genealogia, segundo número de acesso, genotipo da amostra e hospedeiro - São Paulo - 2013.

Quadro 3- Sequências de VP4 de rotavírus do grupo A, recuperadas do GenBank, utilizadas para a reconstrução da genealogia, segundo número de acesso, genotipo da amostra e hospedeiro - São Paulo - 2013.

Quadro 4- Sequências de VP6 de rotavírus do grupo D, recuperadas do GenBank, utilizadas para a reconstrução da genealogia, segundo número de acesso, hospedeiro e grupo - São Paulo - 2013 .50

Quadro 5- Relação das amostras de campo positivas para rotavírus do grupo A, com sequenciamento parcial do gene codificador da VP7, de acordo com estado, tipo de criação e número de acesso GenBank - São Paulo - 2013

Quadro 6- Relação das amostras de campo positivas para rotavírus do grupo A, com sequenciamento parcial do gene codificador da VP4, de acordo com estado, tipo de criação e número de acesso GenBank - São Paulo - 2013

Quadro 7- Relação das amostras de campo positivas para rotavírus do grupo D, com sequenciamento parcial do gene codificador da VP6, de acordo com estado, tipo de criação e número de acesso GenBank - São Paulo - 2013

Quadro 8- Valores de identidade nucleotídica e de aminoácidos da região consensual das sequências de rotavírus geradas neste estudo (USPAVRV05 e USPAVRV06), bem como frente às demais representativas do genotipo G19 de VP7 de rotavírus do grupo A depositadas no GenBank - São Paulo - 2013. 
Quadro 9- Valores de identidade nucleotídica e de aminoácidos da região consensual das sequências de rotavírus geradas neste estudo (USPAVRV01 a USPAVRV06), bem como frente às demais representativas do genotipo P[31] de VP4 de rotavírus do grupo A depositadas no GenBank - São Paulo - 2013.....................................78

Quadro 10- Valores de identidade nucleotídica e de aminoácidos da região consensual das sequências de rotavírus geradas neste estudo (USPAVRV07 e USPAVRV08), bem como frente às demais representativas do genotipo P[31] de VP4 de rotavírus do grupo A depositadas no GenBank - São Paulo - 2013

Quadro 11- Valores de identidade nucleotídica e de aminoácidos da região consensual das sequências de rotavírus do grupo D geradas neste estudo (AVRVBR1 a AVRVBR4), bem como frente às demais representativas de rotavírus do grupo D em aves depositadas no GenBank - São Paulo - 2013. .80 


\section{LISTA DE TABELAS}

Tabela 1- Concordância entre os resultados das reações de ELISA e PAGE.

Tabela 2- Concordância entre os resultados das reações de PAGE e PCR (NSP5) de rotavírus do grupo A

Tabela 3- Concordância entre os resultados das reações de ELISA e PCR (NSP5) de rotavírus do grupo A

Tabela 4- Resultados dos testes diagnósticos e de genotipagem para rotavírus do grupo A e de PCR para rotavírus do grupo D das amostras de pools de aves do presente estudo São Paulo - 2013. 


\section{LISTA DE APÊNDICES}

APÊNCIDE A- Sequências nucleotídicas parciais de NSP5, VP7, VP4 de rotavírus aviário do grupo A e sequências nucleotídicas parciais de VP6 geradas no presente. 101

APÊNDICE B- Alinhamento das sequências parciais de nucleotídeos contemplando as amostras geradas neste estudo com as demais do GenBank representativas do genotipo 19 da VP7 e do genótipo 31 da VP4 e alinhamento das sequências parciais de nucleotídeos contemplando as amostras de rotavírus do grupo D geradas nesse estudo com as demais sequências do grupo D recuperadas do Genbank. 109

APÊNDICE C- Alinhamento das sequências parciais convertidas em aminoácidos contemplando as amostras geradas neste estudo com as demais do GenBank representativas do genotipo 19 da VP7 e do genótipo 31 da VP4 e alinhamento das sequências parciais convertidas em aminoácidos das amostras de rotavírus do grupo D geradas neste estudo com as demais do grupo D recuperadas do GenBank.

APÊNDICE D- Valores de similaridade nucleotídica e de aminoácidos da região consensual das sequências de rotavírus do grupo A geradas neste estudo (USPARV05 e USPARV06) frente às demais representativas do genotipo G19 de VP7 depositadas no GenBank. As áreas em branco representam as identidades nucleotídicas, e as cinzas, as identidades de aminoácidos - São Paulo 2013.

APÊNDICE E- Valores de similaridade nucleotídica e de aminoácidos da região consensual das sequências de rotavírus do grupo A geradas neste estudo (USPARV01 a USPARV06) frente às demais representativas do genotipo P[31] de VP4 depositadas no GenBank. As áreas em branco representam as identidades nucleotídicas, e as cinzas, as identidades de aminoácidos - São Paulo 2013. 
APÊNDICE F- Valores de similaridade nucleotídica e de aminoácidos da região consensual das sequências de rotavírus do grupo D geradas neste estudo (AVRVBR01 a AVRVBR04) frente às demais representativas também do grupo D (VP6) no GenBank. As áreas em branco representam as identidades nucleotídicas, e as cinzas, as identidades de aminoácidos - São Paulo - 2013 ...................119 
aa = aminoácido

ADRV-N = New Aldult Diarrhea Rotavirus

BLAST $/ \mathrm{n}=$ Basic Local Alignment Search Tool

ELISA = enzyme-linked immunosorbent assay

$\mathrm{Ca}^{++}=$íons clácio

$\mathrm{Cl}^{-}=$íons cloro

DEPC $=$ dietil-pirocarbonato

DLP = double-layered particle

$\mathrm{dNTP}=$ deoxinucleosídeo-trifosfato

dsRNA $=$ RNA de fita dupla

EDTA = ácido etilenoamino tetra-acético

et al. $=$ e colaboradores

FDA $=$ Food and Drug Administration

$\mathrm{g}=$ aceleração da gravidade terrestre $(9,8 \mathrm{~m} / \mathrm{s} 2)$

$\mathrm{kDA}=$ quiloDalton

$\mathrm{M}=$ Molar

$\mathrm{mL}=$ mililitro

$\mathrm{mM}=$ milimolar

mRNA $=$ RNA mensageiro

$\mathrm{NCDV}=$ Nebraska calf diarrhea vírus

$\mathrm{ng}=$ nanograma

$\mathrm{nt}=$ nucleotídeo

$\mathrm{NSP}=$ proteína não estrutural

NTPase $=$ proteína nucleosídeo trifosfatase

$\mathrm{ORF}=$ open reading frame

$\mathrm{PIB}=$ Produto Interno Bruto

PAGE $=$ eletroforese em gel de poliacrilamida

$\mathrm{pb}=$ pares de bases

$\mathrm{pH}=$ potencial hidrogeniônico

$\mathrm{PCR}=$ reação em cadeia pela polimerase 
PNSA $=$ Programa Nacional de Sanidade Avícola

$\mathrm{p} / \mathrm{v}=$ proporção peso e volume

RNA = ácido ribonucleico

RT-PCR = reação em cadeia pela polimerase precedida por transcrição reversa

RTPase $=$ RNA triofosfatase

ssRNA $=$ RNA de fita simples

$\mathrm{Tm}=$ temperatura de Melting

TRIS $=$ hidroximetil-aminometano

$\mathrm{VP}=$ proteína estrutural

$\mu \mathrm{g}=$ micrograma

$\mu \mathrm{L}=$ microlitro 


\section{SUMÁRIO}

1 INTRODUÇÃ̃O

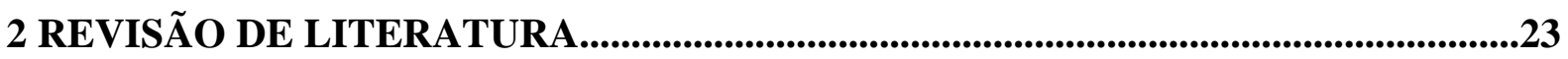

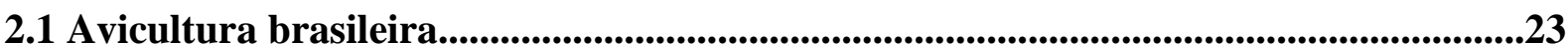

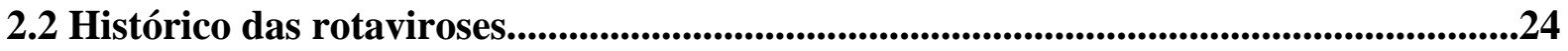

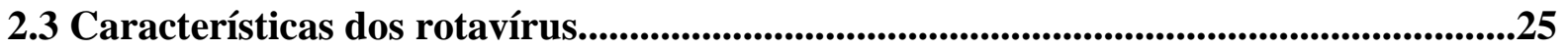

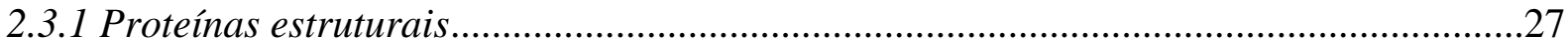

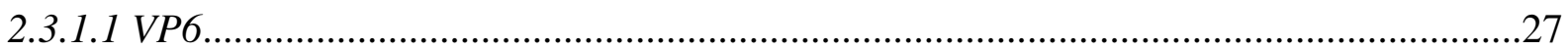

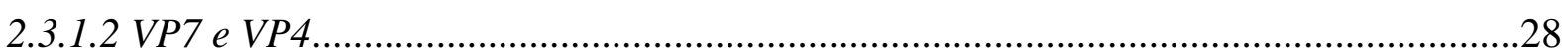

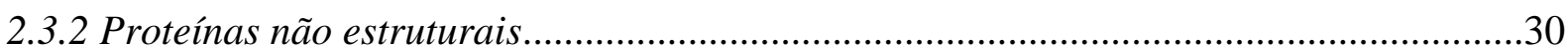

2.4 Replicação viral.............................................................................................................................32

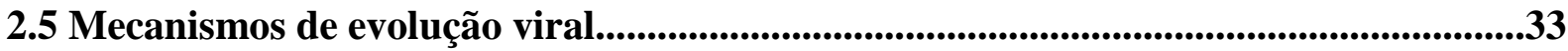

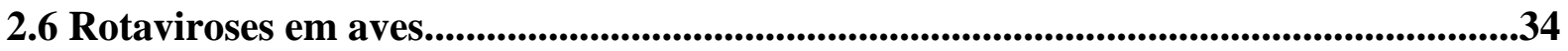

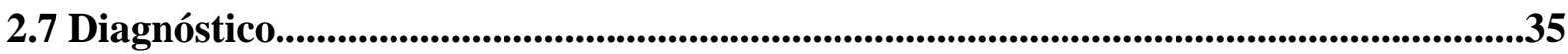

2.8 Prevenção.....................................................................................................................................................36

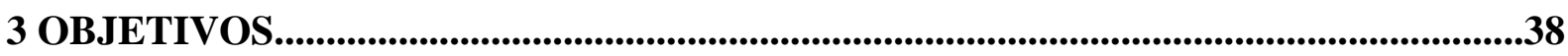

4 MATERIAL E MÉTODOS..............................................................................................39

4.1 Amostras clínicas........................................................................................................................39

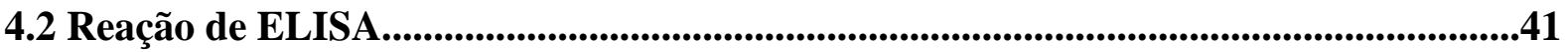

4.3 Reação de Eletroforese em Gel de Poliacrilamida...............................................................41

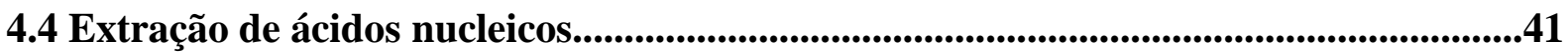

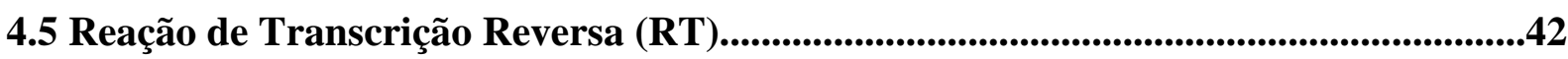

4.6 Reação em Cadeia pela Polimerase (PCR)..................................................................42

4.6.1 Detecção de rotavírus do grupo A - gene NSP5 .............................................................42

4.6.2 Reações de genotipagem do rotavírus - genes VP4 e VP7.............................................43

4.6.2.1 Desenho de primer visando o gene VP7 de rotavírus aviários.....................................44

4.6.3 Detecção de rotavírus do grupo D - gene VP6...........................................................45

4.7 Reação de sequenciamento nucleotídico.......................................................................46

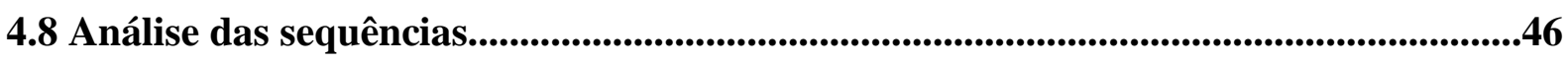

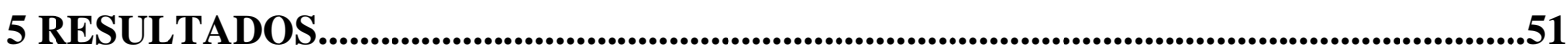

5.1 Reação de ELISA..........................................................................................................................51

5.2 Reação de Eletroforese em Gel de Poliacrilamida................................................................51

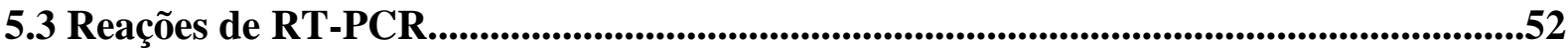


5.3.1 Detecção de rotavírus do grupo A visando o gene codificador da NSP5

5.3.2 Concordância entre as reações de RT-PCR, PAGE e ELISA..........................................53

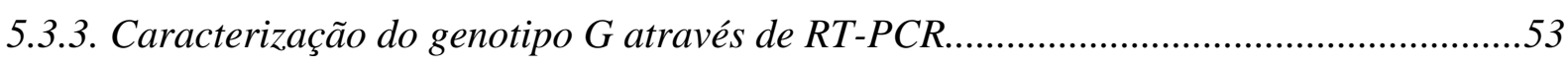

5.3.4 Detecção de rotavírus por RT-PCR visando o gene codificador da VP7 com primers

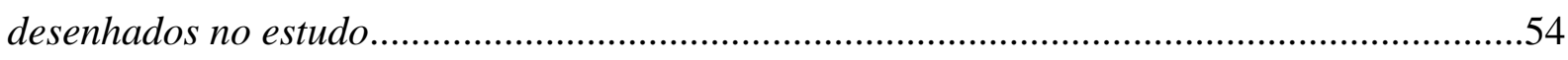

5.3.5 Caracterização do genotipo P através de RT-PCR …....................................................54

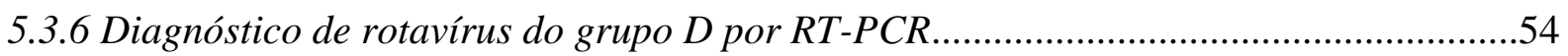

5.4 Reação de sequenciamento nucleotídico......................................................................58

5.4.1Confirmação das RT-PCR visando o gene codificador da NSP5 .....................................58

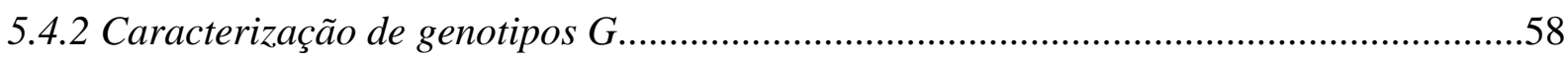

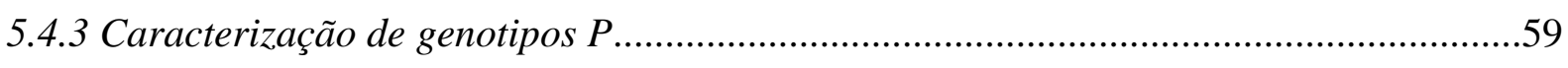

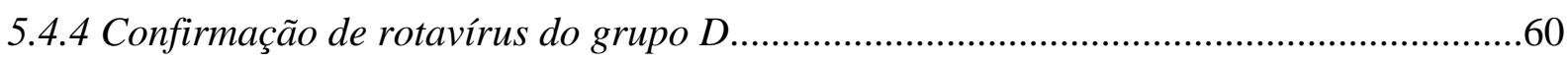

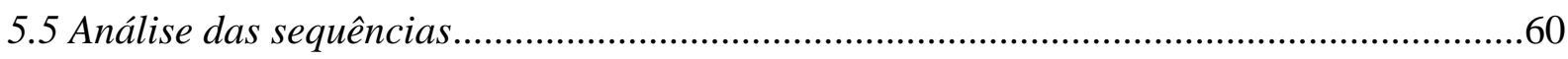

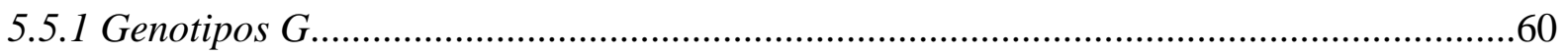

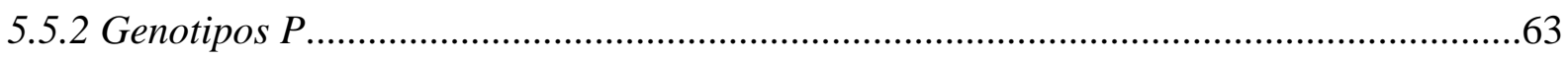

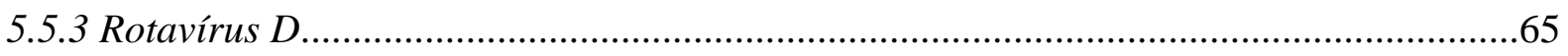

5.6 Alinhamento das sequências..........................................................................................67

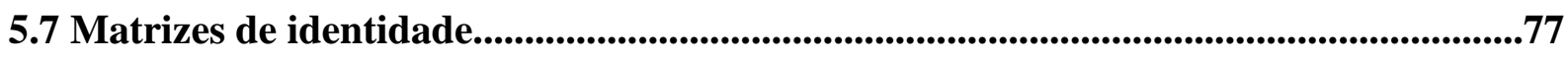

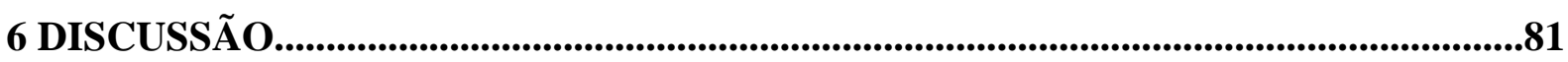

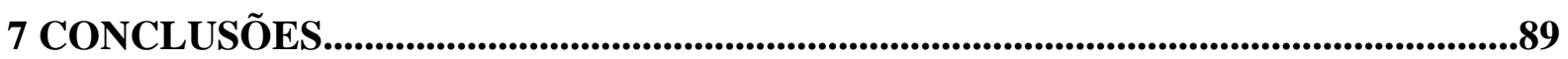

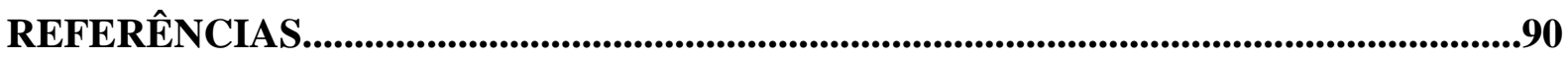

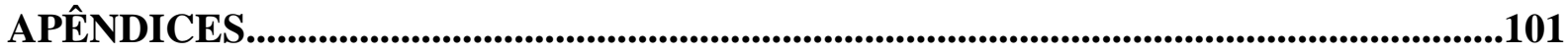




\section{INTRODUÇÃO}

A avicultura brasileira encontra-se entre as mais tecnificadas e desenvolvidas do mundo, empregando mais de 4,5 milhões de pessoas, direta e indiretamente, respondendo por quase $1,5 \%$ do Produto Interno Bruto (PIB) nacional. O setor é representado por dezenas de milhares de produtores integrados, centenas de empresas beneficiadoras e dezenas de empresas exportadoras. A importância social da avicultura no Brasil se verifica também pela presença maciça no interior do país, principalmente nos estados do Sul e Sudeste, onde em muitas cidades a produção de frangos é a principal atividade econômica (UBABEF, 2012).

Uma grande variedade de agentes pode afetar o trato gastrointestinal das aves causando diarreias (PORTER, 1998), entre eles bactérias, protozoários e vírus, atuando de forma isolada ou em associação; sendo os vírus RNA fita dupla segmentados os mais comumente implicados nas infecções (ALFIERI et al., 2000).

Dentre os agentes virais, os rotavírus são um dos principais causadores de diarreia (ALFIERI, 1994), amplamente distribuídos entre seres humanos e várias espécies animais, incluindo mamíferos e aves (ESTES; KAPIKIAN, 2007; MARTELLA et al., 2010).

$\mathrm{Na}$ avicultura o rotavírus causa impacto na sanidade e performance do lotes devido a mecanismos que permitem a disseminação epidêmica da doença, tal como alojamento de grande número de aves por lote (INSTITUTO ADOLFO LUTZ, 2004) combinado com a elevada concentração de partículas virais na fase aguda da doença, em torno de $10^{11}$ partículas/mL de fezes (KOOPMANS; DUIZER, 2004), já que a via de transmissão do rotavírus se dá pela via fecal-oral, podendo ocorrer também através de água e alimentos contaminados (ESTES; KAPIKIAN, 2007).

Nesse contexto de aumento de produção e consumo, é crescente a preocupação em relação à sanidade da avicultura brasileira. Levando-se em consideração que existe pouca investigação científica acerca da participação dos rotavírus nas diarreias de aves, propõe-se neste estudo determinar a frequência de ocorrência de rotavírus (dos grupos A e D) e caracterizar os genotipos encontrados (do grupo A) das amostras circulantes nas suas diferentes modalidades de produção (avós, matrizes, corte e postura), e com isso gerar conhecimentos acerca da cadeia epidemiológica nos diferentes tipos de criações comerciais 
brasileiras, principalmente no tocante ao delineamento de medidas profiláticas mais efetivas e suas relações com outras espécies animais. 


\section{REVISÃO DE LITERATURA}

Neste tópico está apresentada uma seleção de estudos relacionados às rotaviroses, com ênfase na sua ocorrência em aves.

\subsection{Avicultura brasileira}

A indústria avícola é uma das principais fontes geradoras de proteína de origem animal, destinadas ao consumo humano. A avicultura brasileira atingiu produtividade e qualidade comparáveis às obtidas pelos países mais desenvolvidos do mundo, promovendo, entre outras contribuições, a geração de divisas de exportação (LOPES, 1992).

No Brasil, a avicultura teve um importante crescimento especialmente no ano de 2009 quando a produção atingiu a marca histórica de 10,9 milhões de toneladas, o que representou $15,3 \%$ da produção mundial, garantindo ao Brasil uma posição entre os três maiores produtores mundiais de carne de frango, com Estados Unidos e China, segundo dados da ABEF (Associação Brasileira de Exportadores de Frango) (UBABEF, 2012).

A produção e abate de frangos no Brasil, estão localizadas principalmente na Região Sul do Brasil. Destacam-se os Estados do Paraná, Santa Catarina e Rio Grande do Sul, sendo estes responsáveis por 61,53\% da produção de carne de frango brasileira em 2011(UBABEF, 2012). No que diz respeito à produção de ovos, o maior estado produtor é São Paulo, com $35,85 \%$ da produção brasileira. As exportações brasileiras de ovos somaram 16,6 mil toneladas em 2011 e estima-se que o plantel médio de poedeiras comerciais em 2011, tenha sido próximo a 866,945 unidades de aves alojadas (UBABEF, 2012).

Nesse contexto de aumento de produção e consumo, é crescente a preocupação em relação à sanidade da avicultura brasileira. Assim, através da Portaria nº 193, de 19/09/1994, o Ministério da Agricultura Pecuária e Abastecimento consolidou o Programa Nacional de Sanidade Avícola (PNSA) (BRASIL, 1994), tendo como principais objetivos definir ações que possibilitem a certificação sanitária do plantel nacional e favorecer a elaboração de 
produtos avícolas para o mercado interno e externo; ressaltando-se as normas técnicas para registro, fiscalização e controle de estabelecimentos de reprodução e comerciais, de corte e postura, além das normativas específicas para controle das doenças como salmonelose, micoplasmose e doença de Newcastle e para a prevenção da influenza aviária.

Doenças infecciosas que afetam o trato digestivo das aves comerciais são importantes tanto em função das perdas econômicas que estas causam quanto pela afecção de outros sistemas das aves, o que somado, leva à diminuição da produtividade (BIUTRAGO, 2003). Por outro lado, constata-se que tais doenças ainda não estão contempladas dentro do PNSA, aliado ao fato de que no Brasil, como veremos adiante, existe pouca investigação científica acerca da participação dos rotavírus nas diarreias de aves.

\subsection{Histórico das rotaviroses}

Os primeiros estudos sobre os rotavírus datam da década de 1960, ao serem reproduzidos quadros de diarreia em bezerros a partir de inoculações experimentais de filtrados livres de bactérias (MEBUS et al., 1969).

Na década seguinte, diferentes estudos visaram, sobretudo a caracterização do agente no que diz respeito a morfologia das partículas por microscopia eletrônica e a associação entre a sintomatologia clínica (diarreias e gastroenterites) e a presença do agente em diferentes espécies animais e humanos (BISHOP et al., 1973; FLEWETT et al., 1974).

Em 1978, o gênero Rotavirus (do latim "rota", significando "roda") foi oficialmente reconhecido pelo Comitê Internacional de Taxonomia de Vírus (ICTV) (MATTHEWS, 1979).

Em aves, os rotavírus foram primeiramente observados em conteúdo entérico de perus de duas a três semanas de idade, com diarreia aquosa e alta mortalidade na Dakota do Sul, Estados Unidos (BERGERLAND et al., 1977). Posteriormente foram detectados em conteúdo intestinal diarreico de perus na Irlanda do Norte (MCNULTY, 1978) e em fezes diarreicas de poedeiras comerciais na Inglaterra (JONES, et al., 1979). 
Em 1979, Jones, et al., recomendavam o isolamento viral em cultivo celular a partir de material fecal ou conteúdo intestinal, seguido da microscopia eletrônica no diagnóstico de rotavírus em perus com diarreia ou de galinhas ainda que assintomáticas (MCNULTY et al., 1979a).

Desde então o rotavírus tem sido identificado em uma variedade de espécies aviárias, incluindo frangos de corte, aves de postura, perus, pombos, patos e faisões, com sinais clínicos de enterite ou de aves aparentemente saudáveis (MCNULTY, 2003).

No Brasil, rotavírus aviários pertencentes ao grupo A foram primeiramente detectados em fezes de frango de corte com diarreia através das técnicas de PAGE e ELISA (ALFIERI et al., 1989) e posteriormente descritos também em conteúdo intestinal de poedeiras e frangos de corte (VILLARREAL et al., 2006), em amostras fecais também de frango de corte (TAMEHIRO et al., 2003), em criações comerciais de perus (ASANO et al., 2011) e em amostras fecais de avestruzes (SILVA et al., 2012).

A primeira sequência completa de rotavírus do grupo D foi determinada por Trojnar et al. (2010), tendo sido descritos em frangos na Europa e Bangladesh (OTTO et al., 2012), enquanto que no Brasil em amostras fecais de aves no Pará (BEZERRA et al., 2012).

\subsection{Características dos rotavírus}

As espécies de rotavírus são pertencentes à família Reoviridae, subfamília Sedoreovirinae e gênero Rotavirus (KING et al., 2012). Como veremos mais detalhadamente a seguir, baseados em reações sorológicas e/ou moleculares, os rotavírus podem ser classificados em pelo menos 6 grupos (A-F), sendo os do grupo A os mais prevalentes em diversas espécies animais (RAMING et al., 2005).

Partículas virais completas de rotavírus do grupo A medem em torno de 100nm e quando observadas pela microscopia eletrônica, apresentam um capsídeo de simetria icosaédrica, não possuem envelope e são compostas por três camadas proteicas distintas (ESTES; KAPIKIAN, 2007). 
Os rotavírus contêm um genoma constituído por 11 segmentos de RNA fita dupla (dsRNA), onde cada segmento codifica uma proteína - exceto o $11^{\circ}$ que é bicistrônico sendo seis delas estruturais (VP1, VP2, VP3, VP4, VP6 e VP7) e seis não estruturais (NSP1, NSP2, NSP3, NSP4, NSP5 e NSP6 (ESTES; KAPIKIAN, 2007).

Cada segmento do RNA de fita dupla (dsRNA) é dividido em três regiões: uma região 5' não codificadora com uma extremidade guanidina, um quadro de leitura aberta (ORF, "open reading frame") e uma região 3' não codificadora com um extremidade citosina (ESTES; KAPIKIAN, 2007).

O tamanho em pares de bases $(\mathrm{pb})$ do genoma completo de rotavírus do grupo A apresenta variações entre amostras de aves (19.064 pb) e de mamíferos (18.526 pb). No caso de rotavírus do grupo D o tamanho é de 18.500 pb (TROJNAR et al., 2010).

A visualização dos 11 segmentos dos rotavírus pode ser obtida mediante o teste de PAGE. De acordo com os padrões de mobilidade, definem-se quatro classes de migração: classe I (segmentos 1, 2, 3 e 4), II (5 e 6), III (7, 8 e 9) e IV (10 e 11). Este último determina o "perfil longo" (migração rápida) ou "curto" (lenta), havendo, ainda, o padrão "super curto" (ESTES, 2001; KAPIKIAN et al., 2001). Ocasionalmente os rotavírus pertencentes ao grupo A exibem a configuração do perfil aviário, com a típica distribuição 5:1:3:2. Os integrantes dos grupos B e D denotam padrão 4:2:2:3, e o C, por sua vez, 4:3:2:2 (MASCARENHAS, 2006).

Os rotavírus caracterizam-se por elevada eliminação de partículas virais durante a fase aguda da doença, eliminando em torno de $10^{11}$ partículas/mL de fezes (KOOPMANS; DUIZER, 2004), além de possuírem elevada resistência às condições ambientais, permanecendo estável por até 60 dias em esgoto comum ou até mesmo infectantes em temperaturas tão altas quanto $50^{\circ} \mathrm{C}$ (FAUQUET et al., 2005), o que leva a maior preocupação quanto à manutenção da sanidade dos processos produtivos das aves (ALFIERI et al.,2000). 


\subsubsection{Proteínas estruturais}

O capsídeo interno - ou "core" - que circunda o genoma viral é formado por três proteínas (VP1, VP2 e VP3). A VP1 (125 kDa) é uma RNA polimerase RNA-dependente responsável tanto pela transcrição quanto pela replicação viral, no entanto é ativa apenas na presença da VP2. A VP3 tem a função de guanililtransferase e liga-se à fita simples de RNA (ssRNA) transportando-a para que sirva de molde para as fitas de dsRNA. As proteínas VP1 e VP3 formam complexos que estão encaixados na VP2, que por analogia a outros Reovírus, determinam a organização estrutural dos componentes do capsídeo externo, fator esse refletidos na natureza altamente conservada da VP2 (ESTES, 2001; KAPIKIAN, 2001; MATTHIJNSSENS et al., 2008; KING et al., 2012).

\subsubsection{VP6}

A proteína estrutural VP6 (41 kDa, 397 aa) é codificada pelo $6^{\circ}$ segmento (13.546 pb) do genoma viral, sendo considerada como o maior componente proteico estrutural do vírion (GREIG et al., 2006; ESTES; KAPIKIAN, 2007).

O capsídeo intermediário do vírus é formado por 780 cadeias polipeptídicas de VP6 dispostos em 260 unidades triméricas. O sítio de trimerização dessa proteína situa-se entre os aminoácidos 246 e 314 (CHARPILIENNE et al., 2002).

A VP6 forma trímeros e túbulos espontaneamente e devido a isso é extremamente estável mantendo a sua conformação independente da presença de outras proteínas (GREIG et al., 2006; ESTES; KAPIKIAN, 2007).

Seu importante papel estrutural é ainda reafirmado devido à existência de dois domínios distintos, um proximal (domínio B de $\alpha$-hélices) e um distal (domíno $\mathrm{H}$ de folhas$\beta$ ), o que permite sua interação com a proteína do "core" (VP2) e com ambas as proteínas do capsídeo externo (VP7 e VP4) (CHARPILIENNE et al., 2002). 
São proteínas altamente hidrofóbicas, sendo que os resíduos de aminoácidos no domínio B de VP6 nas posições 32 (Q), 65 (L), 70 (L), 71 (L) interagem com a VP2 promovendo estabilidade do duplo capsídeo (CHARPILIENNE et al., 2002).

A VP6 é uma de uma proteína conservada e imunogênica que serve de base para a classificação do rotavírus em grupos (A-G) e subgrupos específicos (SG I, SG II ou SG I e II) de acordo com a reatividade a anticorpos monoclonais (KING et al., 2012).

Temos, portanto, a classificação dos rotavírus em grupos de A a G de acordo com a reatividade de anticorpos ou sequenciamento genético da VP6 (RAMING et al., 2005; ESTES; KAPIKIAN, 2007). Recentemente um novo grupo de rotavírus, inicialmente designado de ADRV-N ("New Adult Diarrhea Rotavirus") tem sido proposto como rotavírus do grupo H, porém baseado apenas em características moleculares (ALAM et al., 2007; MATTHIJNSSENS et al., 2011).

Rotavírus dos grupos A, B e C são encontrados tanto em humanos quanto em animais, enquanto grupo $\mathrm{E}$ em suínos e os grupos $\mathrm{D}, \mathrm{F}$ e $\mathrm{G}$ descritos até o momento apenas em aves (RAMING et al., 2005; ESTES; KAPIKIAN, 2007).

\subsubsection{VP7 e VP4}

As proteínas VP7 e VP4 formam o capsídeo externo do vírus e são necessárias para a infectividade. O capsídeo é formado por 260 trímeros de VP7 no qual estão projetados 60 trímeros de VP4 (KING et al., 2012).

A glicoproteína VP7 (codificada pelo $9^{\circ}$ segmento genômico), componente primário do capsídeo externo, é a segunda mais abundante do vírion. Forma a matriz do capsídeo sendo responsável pela indução de anticorpos neutralizantes da partícula viral (MATTION et al., 1994).

A VP7 possui 326 resíduos de aminoácidos, contendo dois domínios hidrofóbicos chamados de H1 (aa 6 - 23) e H2 (aa 33 - 44) que podem funcionar como uma sequência 
sinalizadora que orienta a VP7 para a membrana retículo endoplasmático (GREEN et al., 1988).

Reconstruções a partir de microscopia eletrônica têm evidenciado sua estrutura trimérica que forma oligômeros com as proteínas VP4 e NSP4 no interior das células infectadas. Possui sítios de ligação com o cálcio que, ao interagirem com o mesmo, estão envolvidas no processo de montagem da VP7 dentro do capsídeo externo (DORMITZER; GREENBERGER, 1992).

No que se refere à VP4, sintetizada pelo $4^{\mathrm{o}}$ segmento genômico, também conhecida como proteína de espícula, é não glicosilada e responsável pela ligação do vírus à célula, possuindo 776 aa e constitui 1,5\% da proteína do vírion (ESTES, 2001).

Trata-se de uma hemaglutinina e sofre clivagem proteolítica resultando na formação de peptídeos VP5* e VP8* que são ligados por um peptídeo de conexão sensível à ação de proteases, sendo que a análise de sequenciamento revelou três sítios de clivagem proteolítica nos resíduos de arginina (ARIAS et al., 1996).

Os peptídeos gerados (VP5* e VP8*) aumentam a infectividade do vírus e induzem alterações conformacionais que aumentam a estabilidade da espícula (KING et al., 2012).

O peptídeo VP5* está associado com a atividade de neutralização cruzada entre os diferentes tipos de VP4, e possivelmente possui os epítopos responsáveis pela adsorção do vírus à célula com uma região variável e outra conservada. Também é associado com a restrição da replicação de certas amostras de rotavírus em cultura de células (GREENBERG et al., 1983b) e à indução de anticorpos neutralizantes, o que leva à promoção de uma imunidade protetora (ESTES; KAPIKIAN, 2007).

Por outro lado, o peptídeo VP8* contém a maioria dos epítopos associados às reações tipo-específicas, onde particularmente uma grande variação foi observada entre os resíduos de aminoácidos 71 e 204 (LARRALDE et al., 1991). Em virtude da VP8* conter uma grande diversidade nos sítios de ligação dos anticorpos monoclonais, especulou-se que ela fique localizada mais externamente na partícula viral, o que poderia explicar as regiões de diversidade dessa região (MACKOW et al., 1988). 
Dada a importância na diferenciação de amostras, foi criado um sistema de classificação baseado na reatividade antigênica da VP4 e VP7, no qual os rotavírus do grupo A foram classificados, por meio de ensaios de neutralização cruzada com soros hiperimunes, em sorotipos G (VP7-glicoproteína) e P (VP4-protease sensível); sendo que até o momento foram identificados 14 sorotipos G e P (KING et al., 2012).

Recentemente, um sistema de uniformização de classificação e nomenclatura, baseado nas sequências de nucleotídeos - além de VP4 e VP7 - foi proposto para a classificação dos rotavírus do grupo A. Este sistema atribui um genotipo para cada um dos 11 segmentos do genoma do vírus de forma que os genes VP7 - VP4 - VP6 - VP1 - VP2 - VP3 - NSP1 - NSP2 - NSP3 - NSP4 - NSP5/6 são descritos usando as abreviações Gx - P[x] - Ix - Rx - Cx - Mx $\mathrm{A} x-\mathrm{N} x-\mathrm{T} x-\mathrm{E} x-\mathrm{H} x$, respectivamente, onde “ $x$ ” representa um número arábico (MATTHIJNSSENS et al., 2008).

Nesse sentido, quando uma sequência obtida contempla a ORF completa do gene, os valores “cut-off” de identidade da região devem ser seguidos para a classificação do genotipo. Porém nos casos em que apenas a sequência parcial do gene é definida, no mínimo 500 nucleotídeos e 50\% da ORF devem estar determinados, além da porcentagem de similaridade estar acima de $2 \%$ do “cut-off” para que se estabeleça um novo genotipo (MATTHIJNSSENS et al., 2008).

Em espécies aviárias são descritos para a VP7 até o momento os genotipos G7, G17, G18, G19, G22 e G23 e para VP4 os genotipos P[17], P[30], P[31] e P[35] (MATTHIJNSSENS et al., 2008) e mais recentemente descrito o genotipo P[37] em faisão (TROJNAR et al., 2013).

\subsubsection{Proteínas não estruturais}

As proteínas não estruturais são encontradas em partículas virais imaturas durante a infecção e estão relacionadas como processo de replicação e formação da progênie viral (ESTES; KAPIKIAN, 2007). 
A NSP1, codificada pelo $5^{\circ}$ segmento genômico, é a proteína mais variável dentre todas do genoma viral, observando-se $65 \%$ de diversidade de sequência entre amostras de rotavírus do grupo A, o que resulta em elevada diversidade intraespécie (KING et al., 2012), ainda que apresente uma região "zinc-finger" conservada e rica em resíduos de cisteína próxima à região amino-terminal (PATTON, 1993). Possui importante papel no ciclo de replicação do vírus e patogênese viral uma vez que inibe a resposta imune inata do hospedeiro suprimindo a indução de morte celular durante os estágios iniciais da infecção (PATTON et al., 2007).

Já NSP2, codificada pelo $8^{\circ}$ segmento genômico, possui importante função na formação dos viroplasmas, ao interagir com a NSP5, e na replicação do genoma viral, tratando-se uma proteína multifuncional que se liga de forma inespecífica ao ssRNA para início da síntese de dsRNA. Possui adicionalmente as atividades de NTPase, RNA triofosfatase (RTPase) e de nucleosídeo difosfato quinase (TARAPOREWALA; PATTON, 2001)

Por sua vez a NSP3, codificada pelo $7^{\circ}$ segmento do genoma viral, também é uma proteína multifuncional e se liga especificamente ao terminal 3' dos mRNAs (RNA mensageiro) por meio de sua região amino terminal (KING et al., 2012) com funções de ligação ao RNA viral e regulação da tradução (ESTES; KAPIKIAN, 2007).

Finalmente, as NSP5/6 são codificadas por duas ORF's no mesmo segmento viral $\left(11^{\circ}\right)$. A NSP5 é uma fosfoproteína rica em resíduos de serina e treonina, modificada póstranslacionalmente por fosforilação e glicosilação (BEROIS et al., 2003). Possui atividades de ligação com ssRNA e dsRNA, forma dímeros e é essencial para a formação dos viroplasmas e replicação do genoma viral. Nas células infectadas são encontrados múltiplos isômeros fosforilados de NSP5, modificação essa estimulada pela NSP2 e mediada por quinase celular e possivelmente por uma atividade de autoquinase da própria NSP5. O domínio carboxiterminal da NSP5 é necessário para a hiperfosforilação e interação com a NSP6, proteína de expressão demonstrada apenas em poucas amostras e de função ainda não esclarecida totalmente (KING et al., 2012), sabe-se, contudo que a NSP6 é degradada dentro de aproximadamente duas horas após sua síntese (RAINSFORD; MCCRAE, 2007). 


\subsection{Replicação viral}

O ciclo de replicação de diversas amostras de rotavírus animal, o qual está normalmente completo entre 12 a 15 horas a $37^{\circ} \mathrm{C}$, tem sido estudado principalmente em culturas de células de rim de macaco (KING et al., 2012).

Os estágios iniciais da replicação do rotavírus envolve a adsorção viral mediada pela proteína VP4, e por seus produtos de clivagem, aos receptores celulares e entrada na célula. Dentre os receptores celulares envolvidos estão alguns gangliosídeos além de alguns tipos de integrinas e "heat shock protein" como co-receptores. Embora seu papel nos estágios iniciais de infecção viral ainda não esteja elucidado completamente, já foi demonstrado que a VP7 interage com a superfície celular logo após a ligação das espículas aos receptores (ESTES, 1996; KING et al., 2012).

Estudos indicam que o vírus pode entrar na célula por endocitose, mediada pelo receptor celular ou por penetração direta pela membrana (KING et al., 2012). Em ambos os casos, no momento da entrada do vírus na célula a partícula contendo os três envoltórios, sob ação de enzimas lisossomais, perde o capsídeo externo composto de VP4 e VP7, levando à liberação de uma DLP (“double layer protein”) transcricionalmente ativa para o citoplasma da célula (ARIAS et al., 2004).

O ciclo replicativo dos rotavírus é independente de estruturas nucleares ocorrendo integralmente no citoplasma celular. A proteína VP1 modula a síntese dos primeiros transcritos de RNA viral que funcionam como mRNA e também de molde para a síntese de dsRNA constituinte da progênie viral. Essa transcrição é denominada assimétrica já que os transcritos são fitas de polaridade positiva que utilizam como molde fitas de sentido negativo dos RNAs genômicos (KAPIKIAN, 2001).

Acredita-se que a síntese de mRNA viral necessite da presença da proteína VP6, visto que provavelmente esta interaja conformacionalmente com a VP1 uma vez que a sua remoção leva à alteração de VP1 que deixa de ser funcional (CHARPILIENNE et al., 2002).

Durante a replicação uma grande quantidade de proteínas estruturais (VP1, VP2 e VP3) e não estruturais (NSP2 e NSP5) se acumulam resultando em inclusões citoplasmáticas 
conhecidas como viroplasmas, no interior das quais ocorre a replicação do genoma, síntese do “core” viral e morfogênese de novas partículas virais (ESTES; KAPIKIAN, 2007). Enquanto isso, os demais RNA (+) adentram no core recém-formado para servirem de molde para a síntese dos RNA (-), novamente por ação da VP1 como RNA polimerase, levando assim à formação das fitas duplas de RNA no vírion. Em seguida, a VP6 é adicionada ao "core" para formar a segunda camada do capsídeo, resultando numa estrutura de dupla camada semelhante àquela derivada do vírion infectante (KAPIKIAN et al., 2001; CARTER; SAUNDERS, 2007; PATTON et al., 2007).

As partículas de dupla camada deixam os viroplasmas iniciando um brotamento para o interior do retículo endoplasmático mediante a interação dessas partículas com a NSP4, por sua vez sintetizada na membrana desta organela celular tal como a VP7. Assim, durante o brotamento, essas partículas adquirem um envoltório lipídico semelhante a uma vesícula contendo a VP7. No decorrer desse processo a NSP4 se liga também à VP4 e a maturação culmina com a formação do capsídeo externo, remoção do envoltório lipídico e saída do vírion da célula por lise ou exocitose (ARIAS, 2004; PATTON et al., 2007).

\subsection{Mecanismos de evolução viral}

A diversidade genética dos rotavírus está associada a diferentes mecanismos de evolução, entre eles as mutações pontuais (“drifts”), rearranjos genômicos, reestruturações ("reassortment") (TANIGUCHI; URASAWA, 1995) e recombinações intragênicas (PARRA et al., 2004).

Nas mutações pontuais ocorrem substituições de bases, detectadas por sequenciamento nucleotídico (FLORES et al., 1988), ocasionadas pela pressão de seleção entre vírushospedeiro. Por esse motivo, trata-se de um mecanismo comumente observado nos genes codificadores das proteínas de superfície (VP4 e VP7), por estarem diretamente em contato com os anticorpos neutralizantes (TANIGUCHI; URASAWA, 1995).

Nos rearranjos genéticos são observadas alterações nos trechos de uma sequência dentro de um único segmento genômico, algumas vezes na forma de deleção e 
frequentemente como duplicações. Como resultado, alguns segmentos de RNA perdem suas posições usuais e bandas adicionais são visualizadas pela PAGE (MASCARENHAS et al., 2006). Os rearranjos ocorrem provavelmente por uma falha da RNA polimerase no momento da transcrição, contudo, observa-se que os vírus com os segmentos do genoma rearranjados podem não ser defectivos e, portanto, revelam-se geneticamente estáveis (DESSELBERGER, 1996).

$\mathrm{Na}$ reestruturação, característica apenas dos vírus segmentados, ocorre troca de material genético entre dois vírus similares durante infecções mistas, o que leva ao compartilhamento de segmentos entre eles e aparecimento de novas combinações gênicas (TANIGUCHI; URASAWA, 1995). Tal mecanismo é uma vantagem aos rotavírus, visto que o rearranjo de amostras de animais com as de humanos gera vírus que compartilham segmentos de RNA de ambos, possuindo assim, maior chance de se difundirem em uma nova população (TANIGUCHI; URASAWA, 1995; MARTELLA et al., 2010).

A ocorrência de recombinação intragênica consiste na troca de fragmentos entre duas sequências gênicas, no caso, pertencentes a um mesmo genotipo, diferentemente do rearranjo, em que todo o segmento é trocado. Constitui-se em um importante mecanismo para gerar vírus quiméricos capazes de escaparem ao sistema imune do hospedeiro (PARRA et al., 2004).

\subsection{Rotaviroses em aves}

Rotavirose aviária é uma infecção intestinal que geralmente apresenta alta morbidade e baixa mortalidade (MCNULTY, 2003). Como a principal via de transmissão do rotavírus é indireta, pelo contágio fecal-oral, pode ocorrer também através de água e alimentos contaminados (ESTES; KAPIKIAN, 2007). A transmissão vertical é desconhecida, porém há relatos do isolamento de perus com três dias de idade sugerindo a ocorrência de transmissão transovariana ou contaminação via casca do ovo (THEL;SAIF, 1987).

Em geral, infecções por rotavírus são mais comuns em aves jovens, principalmente nas quatro primeiras semanas de idade, e gradualmente menos frequente em aves adultas 
(KARIN et al., 2007), devido à presença de uma resposta imune humoral mais rápida e intensa (YASON; SCHAT, 1987)

Os rotavírus infectam as células maduras das vilosidades epiteliais do intestino delgado (DENNEHY, 2008) e os sintomas incluem diarreia e depressão (MCNULTY, 2008), aumento da mortalidade e "runting and stunting syndrome", caracterizada principalmente pela perda de peso, também tem sido associadas a infecções por rotavírus em aves (HAYNES et al., 1994). Em condições de campo podem causar manifestações subclínicas ou estar associados à enterite, desidratação, anorexia, baixo ganho de peso e aumento da mortalidade (MCNULTY, 2003; TAMEHIRO et al., 2003).

Cabe ressaltar também o caráter zoonótico do vírus e de transmissão interespécies (PAHO, 2001; COOK et al., 2004), inclusive entre mamíferos e aves tanto em condições experimentais, onde uma amostra de rotavírus de pombos demonstrou ser capaz de infectar e causar diarreia em ratos (MORI et al., 2001), quanto em condições de campo, já que há relatos de isolamento de rotavírus do grupo $\mathrm{A}$, em bezerros, contendo elevado grau de similaridade de sequência de nucleotídeos com rotavírus aviário (BRUSSOW et al., 1992; ROHWEDDER et al., 1995; SCHUMANN et al., 2009).

No Brasil, Asano et al. (2011) detectaram o genotipo tipicamente bovino G6P[1], em conteúdo intestinal diarreico de perus a partir do isolamento em célula MA-104 apontando para ocorrência de transmissão interespécie entre bovinos e aves.

\subsection{Diagnóstico}

Diferentes técnicas de diagnóstico têm sido utilizadas no diagnóstico direto dos rotavírus, por exemplo, a microscopia eletrônica (ATHANASSIOUS et al., 1994), isolamento viral em cultivo celular (MCNULTY et al., 1979ab), porém atualmente são normalmente utilizadas, pela rapidez, disponibilidade de reagentes e facilidade de execução, as técnicas de eletroforese em gel de poliacrilamida (PAGE), ELISA e RT-PCR (ESTES; KAPIKIAN, 2007). 
A PAGE consiste em extrair o RNA viral e observar os segmentos genômicos de acordo com a sua mobilidade eletroforética (HERRING et al., 1982). Tem a vantagem de permitir a detecção de rotavírus de qualquer grupo, apresentando elevada especificidade analítica (ESTES; KAPIKIAN, 2007). Porém possui execução relativamente complexa, dificultando processamento de grande quantidade de amostras, e tem como principal desvantagem a baixa sensibilidade analítica, visto que, é necessária grande quantidade de rotavírus nas fezes para geração do sinal (JEREZ, 1997)

Tais desvantagens foram contornadas com o advento das reações imunoenzimáticas, dentre elas a técnica de ELISA. Trata-se de uma técnica altamente sensível, específica e conveniente na detecção de rotavírus em fezes, porém restrita a um determinado grupo (BEARDS et al., 1984; GREGORI et al., 2000).

A reação de RT-PCR por sua vez, é utilizada em função de sua elevada sensibilidade e especificidade (WALTER, 2001) bem como possibilitar tanto o diagnóstico como a caracterização de amostras virais (GOUVEA et al., 1994ab).

Uma variação da PCR, a multiplex nested RT-PCR tem sido utilizada na detecção de rotavírus (GOUVEA et al., $1994 \mathrm{ab}$ ), consistindo na utilização de diferentes pares de primers com a finalidade de amplificar simultaneamente múltiplas regiões de ácidos nucleicos presentes em uma mesma amostra e tendo como principais vantagens economia de custos, tempo e amostras (RATCLIFF et al., 2007).

\subsection{Prevenção}

Embora o desenvolvimento de vacinas para seres humanos tenha começado décadas atrás, apenas nos últimos anos foi liberado o uso das mesmas (WARD et al., 2008), a exemplo da RotaTeq $^{\text {TM }}$ licenciada em 2006 pela Food and Drug Administration (FDA) (PARASHAR et al., 2006) e Rotarix (BERNSTEIN et al., 1999).

Em veterinária, vacinas inativas e atenuadas para a prevenção de rotaviroses em bezerros, leitões e potros são administradas via parenteral às mães no estágio final da gestação 
com o objetivo de gerar uma maior imunidade passiva aos filhotes através do colostro e aleitamento (MARTELLA et al., 2010).

No que diz respeito às aves, para o nosso conhecimento não estão disponíveis vacinas e não são empregados tratamentos específicos para controlar os quadros clínicos de diarreia.

Portanto a prevenção é feita através de um manejo sanitário adequado que inclui entre outras condutas, controle de temperatura, ventilação e umidade relativa do ar no interior dos galpões, água de boa qualidade, descarte de aves refugo e com sinais de doenças, manejo "all in all out", vazio sanitário, limpeza e desinfecção rigorosa das instalações (ALFIERI et al., 2000). 


\section{OBJETIVOS}

Os objetivos deste estudo são:

a) Pesquisar as frequências de ocorrência de rotavírus (grupos A e D) em amostras fecais de aves provenientes de criações comerciais de frangos de corte, poedeiras, matrizes e avós, localizadas em diferentes regiões brasileiras.

b) Caracterizar os genotipos $\mathrm{G}$ e $\mathrm{P}$ dos rotavírus do grupo A detectados, utilizando-se reações de RT-PCR e sequenciamento nucleotídico. 


\section{MATERIAL E MÉTODOS}

Os métodos e a sequência de atividades deste estudo estão esquematicamente apresentados na figura 1.

Figura 1 - Sequência de atividades realizadas visando a ocorrência e caracterização de amostras de rotavírus aviários

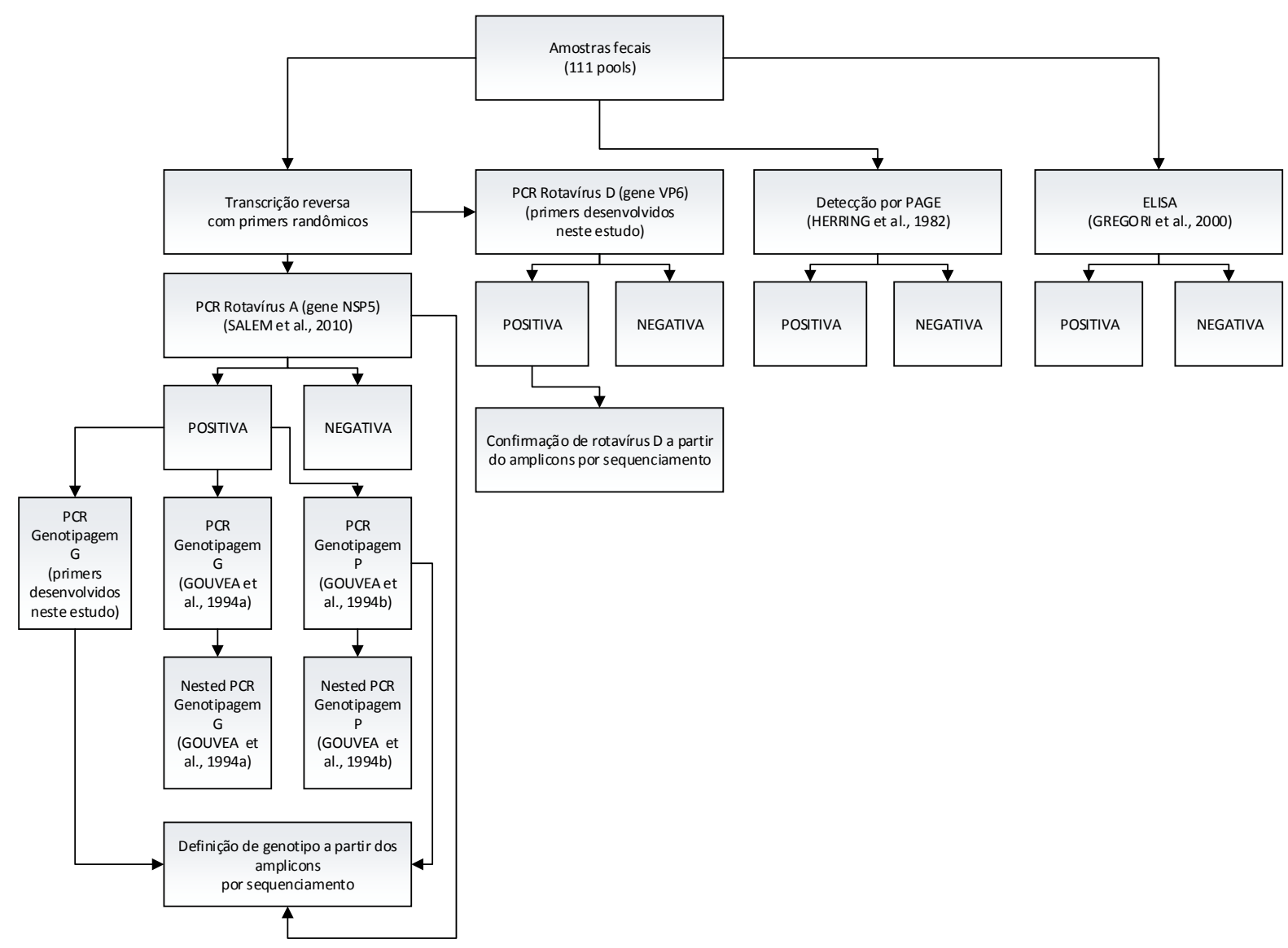

Fonte: Beserra (2013)

\subsection{Amostras clínicas}

Foram testados um total de 111 pools de amostras fecais de aves de diversas idades, oriundas de criações comerciais de frangos de corte, poedeiras, matrizes e avozeiros de 
diferentes regiões brasileiras. Cada pool consistiu no conteúdo entérico de 3 a 5 aves pertencentes a um mesmo lote.

Um total de 52,25\% é oriundo de frangos de corte (de até 40 dias de idade); 12,6\% de galinhas poedeiras; e 17,11\% de matrizes, $2,7 \%$ de avós e 15,3\% das amostras não puderam ser caracterizadas quanto ao tipo de criação. Estas amostras são provenientes de oito estados brasileiros, sendo eles: São Paulo, Paraná, Santa Catarina, Rio Grande do Sul, Espírito Santo, Goiás, Bahia e Ceará.

Dos 111 pools testados, 81 estavam armazenados no Laboratório de Biologia Molecular Aplicada e Sorologia (LABMAS) do Departamento de Medicina Veterinária Preventiva e Saúde Animal da Faculdade de Medicina Veterinária e Zootecnia da USP. Os demais 30 pools são provenientes de colheitas a campo em 3 criações comerciais de frangos de corte com 40 dias de idade, localizadas no município de Louveira (SP), em janeiro de 2012.

Os materiais clínicos foram mantidos em gelo durante a colheita e armazenados a $80^{\circ} \mathrm{C}$ até o seu processamento nas reações de ELISA (item 4.2), PAGE (item 4.3) e RT-PCR (item 4.5).

Foram preparadas suspensões fecais a $10 \%(\mathrm{p} / \mathrm{v})$ em PBS $0,01 \mathrm{M}$ pH 7,4 e clarificadas por centrifugação a $12.000 \mathrm{~g}$ por 15 minutos a $4^{\circ} \mathrm{C}$, sendo então utilizado o sobrenadante nas reações de ELISA e PAGE, enquanto que para os testes moleculares, as amostras foram submetidas ao mesmo procedimento, utilizando em substituição, água ultrapura previamente tratada com DEPC (dietilpirocarbonato) ao invés de tampão PBS.

As reações de ELISA (item 4.2), PAGE (item 4.3) e PCR (item 4.6) foram realizadas em paralelo. 


\subsection{Reação de ELISA}

Foi utilizada a reação de ELISA visando a detecção de rotavírus grupo A em todos os 111 pools de amostras (item 4.1), empregando-se a metodologia previamente descrita por Gregori et al. (2000), tendo como controle positivo a amostra NCDV de rotavírus A e negativo o tampão PBS previamente utilizado na realização de suspensões fecais.

\subsection{Reação de Eletroforese em Gel de Poliacrilamida}

Todas as amostras (item 4.1) foram submetidas à técnica de Eletroforese em Gel de Poliacrilamida (PAGE), de acordo com Herring et al. (1982).

\subsection{Extração de ácidos nucleicos}

As amostras foram submetidas a diferentes reações de RT-PCR, visando a detecção de rotavírus do grupo A; grupo D; genotipagem G (duas diferentes estratégias) e genotipagem P.

Para tanto, foram feitas extrações de RNA empregando-se o reagente TRIzol ${ }^{\circledR}$ (Invitrogen $^{\mathrm{TM}}$ ) de acordo com as instruções do fabricante, a partir do sobrenadante das suspensões fecais (item 4.1). O RNA extraído foi então ressuspendido em $15 \mu \mathrm{L}$ de água previamente tratada com DEPC e mantido a $-80^{\circ} \mathrm{C}$ até o seu processamento nas etapas subsequentes. 


\subsection{Reação de Transcrição Reversa (RT)}

A partir do RNA extraído (item 4.4), as amostras foram submetidas à reação de transcrição reversa (RT) utilizando-se primers randômicos (Invitrogen® Cat. No. 48190011), de acordo com o seguinte protocolo:

- Misturar $7 \mu \mathrm{L}$ da amostra de RNA extraído à solução "RT-mix", que por sua vez é composta por $4 \mu \mathrm{L}$ de First Strand Buffer (Invitrogen ${ }^{\circledR}$ ), $2 \mu \mathrm{L}$ de solução de dNTP a $10 \mathrm{mM}$, $2 \mu \mathrm{L}$ de DTT (100mM), $1 \mu \mathrm{L}$ de Random Primers (50 ng/ $\mu \mathrm{L}$ - Invitrogen ${ }^{\circledR}$ ), $200 \mathrm{U}$ M-MLV Reverse Transcriptase $\left(\right.$ Invitrogen ${ }^{\circledR}$ ) e água ultra-pura para um volume final de reação de 20 $\mu \mathrm{L}$; submetendo-a a seguir ao ciclo de $37^{\circ} \mathrm{C} / 50$ minutos e $70^{\circ} \mathrm{C} / 15$ minutos.

\subsection{Reação em Cadeia pela Polimerase (PCR)}

Neste tópico serão apresentados os procedimentos para realização das reações de PCR.

4.6.1 Detecção de rotavírus do grupo A - gene NSP5

As amostras foram submetidas, como triagem, a amplificação de um fragmento parcial do gene codificador da proteína não estrutural NSP5 dos rotavírus do grupo A, de acordo com Salem et al. (2010), mediante uma reação de nested-PCR, empregando-se os primers P1/P2 e posteriormente P3/P4, gerando respectivamente produtos de 317 pb e 208 $\mathrm{pb}$.

Aquelas que resultaram positivas a este teste, bem como aos testes de ELISA e PAGE, foram submetidas a três reações distintas de PCR, descritas nos tópicos seguintes (4.6.2; 4.6.2.1). 
4.6.2 Reações de genotipagem do rotavírus - genes VP4 e VP7

A amplificação de segmentos das proteínas estruturais VP4 e VP7, objetivando sua genotipagem, foi realizada com "primers" e condições de amplificação previamente descritas por Gouvea et al. (1994a,b), de acordo com o protocolo a seguir:

- Misturar 2,5 $\mu \mathrm{L}$ de cDNA (oriundo da reação de RT) à solução "PCR-mix", que por sua vez é composta por $1 \mathrm{x}$ PCR Buffer (Invitrogen ${ }^{\circledR}$ ), 0,2 $\mathrm{mM}$ de cada $\mathrm{dNTP}, 0,5 \mathrm{pmol} / \mu \mathrm{L}$ de cada "primer" (Con2 e Con3, para caracterização P; Beg9, End9, End9UK, e End9CRW8, para a caracterização G), $2 \mathrm{mM}$ de $\mathrm{MgCl}_{2}, 1,25 \mathrm{U}$ de Taq DNA Polymerase (Invitrogen ${ }^{\circledR}$ ), água q.s.p. $25 \mu \mathrm{L}$; submetidos ao ciclo de $94^{\circ} \mathrm{C} / 3$ minutos, 30 ciclos de $94^{\circ} \mathrm{C} / 1$ minuto, $42^{\circ} \mathrm{C} / 2$ minutos, $72^{\circ} \mathrm{C} / 1$ minuto, seguido de $72^{\circ} \mathrm{C} / 10$ minutos para extensão final.

Para a realização da "nested", um volume de $5 \mu \mathrm{L}$ da primeira amplificação foi adicionado a um novo mix contendo os primers sBeg9, DT6, ET10, HT8, FT5, BT11, para G e Con2, $\mathrm{P}(\mathrm{B} 223), \mathrm{P}(\mathrm{GOTT}), \mathrm{P}(\mathrm{NCDV}), \mathrm{P}(\mathrm{OSU}), \mathrm{P}(\mathrm{UK})$ para $\mathrm{P}$ mantendo-se os demais reagentes, submetendo-os ao ciclo de $94^{\circ} \mathrm{C} / 1,5$ minutos, 25 ciclos de amplificação $\left(94^{\circ} \mathrm{C} / 1\right.$ minuto, $55^{\circ} \mathrm{C} / 2$ minutos e $72^{\circ} \mathrm{C} / 1$ minuto) seguidos por uma extensão final de $70^{\circ} \mathrm{C}$ por 10 minutos.

Por fim, $10 \mu \mathrm{L}$ dos produtos oriundos desta reação foram analisados por eletroforese em gel de agarose a 1,5\% (p/v) em tampão TRIS-borato 0,045 M; EDTA 0,001 M pH 8,0, fazendo-se corar o gel em banho de água com $0,5 \mu \mathrm{g} / \mathrm{mL}$ de brometo de etídio por 10 minutos.

Consideram-se positivas as amostras que apresentaram no gel segmentos amplificados de tamanho correspondente àqueles descritos pelos autores (GOUVEA et al., 1994a,b), tendo como referência a inclusão de DNA ladder 100bp (Invitrogen ${ }^{\circledR}$ ) e utilizando-se como controle positivo a amostra NCDV e como negativo a água empregada em diversas etapas das reações. 
4.6.2.1 Desenho de primer visando o gene VP7 de rotavírus aviários

Uma vez que não foi possível a definição de genotipos $\mathrm{G}$ através da técnica de Gouvea et al. (1994a) nas amostras testadas, foram desenhados primers visando contemplar a diversidade genotípica do gene codificador da VP7 de rotavírus do grupo A em aves. Para tanto, foram importadas sequências nucleotídicas disponíveis no GenBank utilizando-se o programa Bioedit v. 7.1.3.0 (HALL, 1999), de modo a se realizar o alinhamento das mesmas mediante o uso do software ClustalW 2.1 (LARKIN et al., 2007). O par de primers foi desenhado levando-se em consideração o fato de assegurar compatibilidade com senso, mediante a definição de uma área consensual e também dos parâmetros de temperatura de anelamento (Tm); teor (\%) de GC; análise de "hairpins", dímeros ("self-dimer" e "crossdimer"), sequências palíndromas e repetições de um mesmo nucleotídeo ("runs"), avaliados pelo aplicativo on-line Netprimer (http//www.premierbiosoft.com/netprimer/index.hmtl).

O par de primers, suas respectivas áreas de hibridização e parâmetros químicos estão apresentados no quadro 1 .

Todos os 111 pools de amostras fecais foram novamente submetidos a reação de PCR para a amplificação do segmento codificador da VP7. A mistura de reagentes consistiu em: 2,5 $\mu \mathrm{L}$ de cDNA (oriundo da reação de RT) adicionados à solução "PCR-mix", que por sua vez é composta por 1x PCR Buffer (Invitrogen ${ }^{\circledR}$ ), 0,2 mM de cada dNTP, 0,5 pmol/ $\mu \mathrm{L}$ de cada “primer". Ao final, as reações foram submetidas ao ciclo de $94^{\circ} \mathrm{C} / 3$ minutos, 30 ciclos de amplificação $\left(94^{\circ} \mathrm{C} / 45\right.$ segundos, $50^{\circ} \mathrm{C} / 30$ segundos e $72^{\circ} \mathrm{C} / 45$ segundos), seguido por uma extensão final de $72^{\circ} \mathrm{C}$ por 10 minutos.

Por fim, $10 \mu \mathrm{L}$ dos produtos oriundos desta reação foram analisados por eletroforese em gel de agarose a 1,5\% (p/v) em tampão TRIS-borato 0,045 M; EDTA 0,001 M pH 8,0, fazendo-se corar o gel em banho de água com $0,5 \mu \mathrm{g} / \mathrm{mL}$ de brometo de etídio por 10 minutos.

Consideram-se positivas as amostras que apresentaram no gel segmentos amplificados de tamanho correspondente a 863 pb, tendo como referência a inclusão de DNA ladder 100bp (Invitrogen ${ }^{\circledR}$ ). 
Quadro 1 - Primers, sequências, posições no genoma, comprimento do produto e temperatura de melting (TM) do par de primers visando o gene codificador da VP7 de rotavírus do grupo A em aves desenhados durante o estudo

\begin{tabular}{|c|c|c|c|c|}
\hline Primer & Sequência $\left(5^{\prime} \rightarrow 3^{\prime}\right)$ & $\begin{array}{c}\text { Posição no } \\
\text { genoma }\end{array}$ & $\begin{array}{c}\text { Comprimento } \\
\text { do produto }(\mathrm{pb})\end{array}$ & $\begin{array}{c}\text { Temperatura } \\
\text { de Melting } \\
(\mathrm{Tm})\end{array}$ \\
\hline VP7AVEFW & TGTATAGTACTGARTGTACTATCCTT & $3-28$ & 863 & $50^{\circ} \mathrm{C}$ \\
VP7ANYRW & TGCCACCAYYTYTTCC & $876-891$ & & \\
\hline
\end{tabular}

Fonte: Beserra (2013)

4.6.3 Detecção de rotavírus do grupo D - gene VP6

Visando a detecção de rotavírus do grupo D, realizou-se paralelamente reação de PCR visando a amplificação de segmentos da proteína estrutural VP6 utilizando-se primers e condições de tempo e temperatura previamente descritos por Bezerra et al. (2012).

Dessa forma, todos os 111 pools de amostras fecais foram novamente submetidos a reação de PCR. A mistura de reagentes consistiu em: $2,5 \mu \mathrm{L}$ de cDNA (oriundo da reação de RT) adicionados à solução "PCR-mix", que por sua vez é composta por 1x PCR Buffer (Invitrogen ${ }^{\circledR}$ ), 0,2 $\mathrm{mM}$ de cada dNTP, 0,5 pmol/ $\mu \mathrm{L}$ de cada "primer". Ao final as reações submetidas ao ciclo de $93^{\circ} \mathrm{C} / 3$ minutos, 35 ciclos de amplificação $\left(93^{\circ} \mathrm{C} / 1\right.$ minuto, $55^{\circ} \mathrm{C} / 1$ minuto e $72^{\circ} \mathrm{C} / 1$ minuto), seguido por uma extensão final de $78^{\circ} \mathrm{C}$ por 7 minutos.

Os produtos oriundos desta reação foram também analisados por eletroforese em gel de agarose a 1,5\% (p/v) em tampão TRIS-borato 0,045 M; EDTA 0,001 M pH 8,0, fazendo-se corar o gel em banho de água com $0,5 \mu \mathrm{g} / \mathrm{mL}$ de brometo de etídio por 10 minutos.

Consideram-se positivas as amostras que apresentaram no gel segmentos amplificados de tamanho correspondente a 742 pb, tendo como referência a inclusão de DNA ladder 100bp (Invitrogen ${ }^{\circledR}$ ). 
4.7 Reação de sequenciamento nucleotídico

Os respectivos fragmentos amplificados de rotavírus (itens 4.6.2; 4.6.2.1; 4.6.3), bem como 3 amostras positivas por três técnicas de detecção (item 4.2; 4.3; 4.6.1), foram submetidos ao sequenciamento do DNA, para que pudessem ser comparados (em termos de identidade de nucleotídeos e aminoácidos) com amostras anteriormente descritas na literatura.

Os produtos de PCR foram purificados utilizando-se o reagente EXOSAP-it (USB ${ }^{\circledR}$ ) de acordo com o protocolo do fabricante.

Após esta etapa, os produtos foram submetidos a reações de sequenciamento sendo que cada amostra feita em duplicata e cada um dos tubos contendo $2 \mu \mathrm{L}$ do reagente Big-Dye 3.1 (Applied Biosystems $^{\mathrm{TM}}$ ), 1,5 $\mu \mathrm{L}$ de tampão de sequenciamento, $5 \mu \mathrm{M}$ de cada primer senso ou antisenso e $6,0 \mu \mathrm{L}$ do DNA alvo para uma reação final com volume de $10 \mu \mathrm{L}$, sendo submetidos a 40 ciclos de $96^{\circ} \mathrm{C}$ por 1 minuto, $50^{\circ} \mathrm{C}$ por 15 segundos, $60^{\circ} \mathrm{C}$ por 4 minutos, com rampa de $1^{\circ} \mathrm{C}$ por segundo em todas as etapas.

Em seguida utilizou-se o reagente BigDye XTerminator ${ }^{\mathrm{TM}}$, com o objetivo de remover terminadores não incorporados ao DNA, segundo instruções do fabricante. As amostras foram então submetidas a sequenciamento bidirecional de DNA em sequenciador automático ABI3500 (Applied Biosystems ${ }^{\mathrm{TM}}$ ), também de acordo com instruções do fabricante.

\subsection{Análise das sequências}

De posse dos cromatogramas gerados contendo as sequências nucleotídicas pôde-se visualizar as sequências através do aplicativo FinchTv v. 1.4 .0 (ㄷ 2011, Geospiza) e aquelas oriundas dos primers antissenso foram transformadas para o seu reverso e complemento pelo mesmo aplicativo. Em seguida, feita a importação das sequências para o formato FASTA, utilizando-se o software Bioedit v. 7.1.3.0 (HALL, 1999).

Foram verificadas as consistências dos achados através do serviço Blast-n do GenBank, e a partir deste último, importadas as diversas sequências descritas das regiões alvo 
amplificadas, junto ao programa Bioedit v. 7.1.3.0 (HALL, 1999), de modo a se realizar a edição e alinhamento entre as recém-obtidas com aquelas já descritas, mediante o uso do software ClustalW 2.1 (LARKIN et al., 2007).

A relação filogenética para cada um dos genes de rotavírus pesquisados (VP4, VP7 e VP6) foi feita inicialmente através do cálculo da matriz de identidade de nucleotídeos e aminoácidos utilizando-se o software BioEdit v. 7.0.5 (HALL, 1999).

A inferência filogenética dos rotavírus foi realizada mediante uso do programa MEGA versão 5.1 (TAMURA et al., 2011), visando situar as amostras de rotavírus do grupo A de acordo com os seus respectivos genotipos $\mathrm{G}$ e $\mathrm{P}$, e para a determinação de grupo, a partir de sequências de rotavírus até então supostamente pertencentes ao grupo D.

As árvores geradas a partir das sequências nucleotídicas foi construída com o método de "neighbor-joining" através do modelo de substituição "maximum composite likelihood", sendo também definidos os valores de "bootstrap" a partir de 1.000 repetições.

Para realização da inferência filogenética foram recuperadas sequências do GenBank com pelo menos um representante de cada genotipo descrito para VP7 e VP4 demonstradas nos quadros 2 e 3. Já para a VP6 foram recuperadas sequências de pelo menos um representante de cada grupo descrito (Quadro 4). 
Quadro 2 - Sequências de VP7 de rotavírus do grupo A, recuperadas do GenBank, utilizadas para a reconstrução da genealogia, segundo número de acesso, genotipo da amostra e hospedeiro - São Paulo - 2013

\begin{tabular}{|c|c|c|}
\hline Número de Acesso & Genotipo & Hospedeiro \\
\hline K02033 & G1 & Humano \\
\hline AB 118023 & $\mathrm{G} 2$ & Humano \\
\hline D86271 & G3 & Humano \\
\hline X13603 & G4 & Humano \\
\hline X04613 & G5 & Suíno \\
\hline X65940 & G6 & Bovino \\
\hline AB080737 & G7 & Aviário \\
\hline X56784 & G7 & Aviário \\
\hline EF672560 & G8 & Humano \\
\hline AB 180969 & G9 & Humano \\
\hline A01321 & G10 & Humano \\
\hline M23194 & G11 & Suíno \\
\hline M58290 & G12 & Humano \\
\hline JF712560 & G13 & Equino \\
\hline JF712582 & G14 & Equino \\
\hline FJ347116 & G15 & Bovino \\
\hline GQ479955 & G16 & Rato \\
\hline S58166 & G17 & Aviário \\
\hline D82979 & G18 & Aviário \\
\hline FJ169861 & G19 & Aviário \\
\hline EU486975 & G19 & Aviário \\
\hline EU486974 & G19 & Aviário \\
\hline EU486976 & G19 & Aviário \\
\hline EU486977 & G19 & Aviário \\
\hline EU486971 & G19 & Aviário \\
\hline JQ085407 & G19 & Aviário \\
\hline EÜ805773 & G20 & Humano \\
\hline AB454421 & G21 & Bovino \\
\hline EU486973 & G22 & Aviário \\
\hline JX204827 & $\mathrm{G} 22$ & Aviário \\
\hline FN393054 & G23 & Aviário \\
\hline AB513837 & $\mathrm{G} 24$ & Bovino \\
\hline GU983676 & G25 & Morcego \\
\hline AB605258 & G26 & Bovino \\
\hline AB621363 & G27 & Sugar Glider \\
\hline
\end{tabular}

Fonte: Beserra (2013) 
Quadro 3 - Sequências de VP4 de rotavírus do grupo A, recuperadas do GenBank, utilizadas para a reconstrução da genealogia, segundo número de acesso, genotipo da amostra e hospedeiro - São Paulo - 2013

\begin{tabular}{|c|c|c|}
\hline Número de Acesso & Genotipo & Hospedeiro \\
\hline U65924 & $\mathrm{P}[1]$ & Bovino \\
\hline DQ841262 & $\mathrm{P}[2]$ & Simiam \\
\hline D14725 & $\mathrm{P}[3]$ & Canino \\
\hline AJ540227 & $\mathrm{P}[4]$ & Humano \\
\hline M22306 & $\mathrm{P}[5]$ & Bovino \\
\hline L33895 & $\mathrm{P}[6]$ & Humano \\
\hline M33516 & $\mathrm{P}[7]$ & Síno \\
\hline L34161 & $\mathrm{P}[8]$ & Humano \\
\hline D10970 & $\mathrm{P}[9]$ & Humano \\
\hline M60600 & $\mathrm{P}[10]$ & Humano \\
\hline L07934 & $\mathrm{P}[11]$ & Humano \\
\hline JF712580 & $\mathrm{P}[12]$ & Equino \\
\hline DQ003291 & $\mathrm{P}[13]$ & Suíno \\
\hline EF672563 & $\mathrm{P}[14]$ & Humano \\
\hline FJ031027 & $\mathrm{P}[15]$ & Caprino \\
\hline GQ479950 & $\mathrm{P}[16]$ & Murino \\
\hline AB009632 & $\mathrm{P}[17]$ & Aviário \\
\hline D16352 & $\mathrm{P}[17]$ & Bovino \\
\hline JF712558 & $\mathrm{P}[18]$ & Equino \\
\hline AF523677 & $\mathrm{P}[19]$ & Humano \\
\hline U08424 & $\mathrm{P}[20]$ & Murino \\
\hline AF237665 & $\mathrm{P}[21]$ & Bovino \\
\hline AF526374 & $\mathrm{P}[22]$ & Coelho \\
\hline AY174094 & $\mathrm{P}[23]$ & Suíno \\
\hline AY596189 & $\mathrm{P}[24]$ & Simiam \\
\hline GU199520 & $\mathrm{P}[25]$ & Humano \\
\hline DQ061053 & $\mathrm{P}[26]$ & Suíno \\
\hline DQ534016 & $\mathrm{P}[27]$ & Suíno \\
\hline EU805773 & $\mathrm{P}[28]$ & Humano \\
\hline AB454420 & $\mathrm{P}[29]$ & Bovino \\
\hline EU486959 & $\mathrm{P}[30]$ & Aviário \\
\hline EU486960 & $\mathrm{P}[30]$ & Aviário \\
\hline EU485956 & $\mathrm{P}[30]$ & Aviário \\
\hline FJ169856 & $\mathrm{P}[30]$ & Aviário \\
\hline EU486962 & $\mathrm{P}[31]$ & Aviário \\
\hline FJ492835 & $\mathrm{P}[32]$ & Suíno \\
\hline AB513836 & $\mathrm{P}[33]$ & Bovino \\
\hline AB571047 & $\mathrm{P}[34]$ & Suíno \\
\hline JX204825 & $\mathrm{P}[35]$ & Aviário \\
\hline EU486958 & $\mathrm{P}[35]$ & Aviário \\
\hline JX204814 & $\mathrm{P}[37]$ & Aviário \\
\hline
\end{tabular}

Fonte: Beserra (2013) 
Quadro 4 - Sequências de VP6 de rotavírus do grupo D, recuperadas do GenBank, utilizadas para a reconstrução da genealogia, segundo número de acesso, hospedeiro e grupo - São Paulo - 2013

\begin{tabular}{|c|c|c|}
\hline Número de Acesso & Hospedeiro & Grupo \\
\hline & & \\
\hline & & \\
KC579490 & Humano & A \\
JQ740140 & Humano & C \\
NC007553 & Humano & B \\
DQ168033 & Humano & H \\
JX971573 & Humano & H \\
AB738416 & Bovino & A \\
GQ358714 & Bovino & C \\
AB779621 & Bovino & B \\
HQ323753 & Suíno & A \\
JQ085406 & Suíno & C \\
D82980 & Aviário & A \\
D16329 & Aviário & A \\
EF687020 & Aviário & A \\
DQ096805 & Aviário & A \\
NC014516 & Aviário & A \\
JN034684 & Aviário & D \\
JN034682 & Aviário & D \\
JN034680 & Aviário & D \\
JN034685 & Aviário & D \\
JN034683 & Aviário & D \\
JN034681 & Aviário & D \\
JN034679 & Aviário & D \\
JQ065735 & Aviário & D \\
JN703463 & Aviário & D \\
JQ065736 & Aviário & D \\
JQ065734 & Aviário & D \\
HQ403603 & Aviário & D \\
HQ403604 & Aviário & F \\
& Aviário & G \\
\hline
\end{tabular}

Fonte: Beserra (2013) 


\section{RESULTADOS}

Neste tópico serão apresentados os resultados das reações de ELISA, PAGE e RTPCR.

\subsection{Reação de ELISA}

Dos 111 pools de amostras fecais analisados pela técnica de ELISA, 6 deles (6/111 ou $5,4 \%$ ) foram positivos quanto a presença de rotavírus.

Os resultados obtidos por este teste encontram-se na tabela 3. Com relação ao tipo das criações, $66,7 \%$ (4/6) dos pools positivos são oriundos de frangos de corte; 16,6\% (1/6) de avós; e 16,6\% (1/6) de matrizes. No que diz respeito à localização das granjas, 66,7\% (4/6) estão localizadas no estado de São Paulo, 16,6\% (1/6) em Santa Catarina e 16,6\% (1/6) no Rio Grande do Sul.

\subsection{Reação de Eletroforese em Gel de Poliacrilamida}

Dos 111 pools de amostras fecais novamente analisados pela técnica de PAGE, 10 deles (10/111 ou 9\%) foram positivos quanto a presença de rotavírus.

Os resultados obtidos por este teste encontram-se na tabela 3. Com relação ao tipo das criações, 70\%\% (7/10) dos pools positivos são oriundos de frangos de corte; $10 \%$ de avós (1/10); e 20\% de matrizes (2/10), localizadas nos estados de São Paulo, Paraná, Rio Grande do Sul e Santa Catarina.

A relação entre os resultados das reações de ELISA e PAGE é apresentada na tabela 1 a seguir. 
Tabela 1 - Concordância entre os resultados das reações de ELISA e PAGE

\begin{tabular}{lccc}
\hline & \multicolumn{3}{c}{ PAGE } \\
ELISA & Positivo & Negativo & Total \\
\hline Positivo & 3 & 3 & 6 \\
Negativo & 7 & 98 & 105 \\
Total & 10 & 101 & 111 \\
\hline
\end{tabular}

\subsection{Reações de RT-PCR}

Neste tópico serão apresentados os resultados da diferentes reações de RT-PCR realizadas neste estudo.

5.3.1 Detecção de rotavírus do grupo A visando o gene codificador da NSP5

Dos 111 pools de amostras fecais submetidos a RT-PCR, 39 deles (39/111 ou 35,13\%) foram positivos quanto a presença de rotavírus.

Sendo 51,28\% (20/39) oriundos de criações de frango de corte, 23,07\% (9/39) de matrizeiros, $15,38 \%$ de poedeiras (6/39), 2,56\% de avozeiros (1/39) e em 7,69\% (3/39) não foi possível identificar o tipo de criação. As amostras são provenientes dos estados de São Paulo (56,42\% ou 22/39), Paraná (15,38\% ou 6/39), Santa Catarina (10,25\% ou 4/39), Rio Grande do Sul (7,69\% ou 3/39), Goiás (2,56\% ou 1/39) e em 7,69\% (3/39) não foi possível determinar o estado. 
5.3.2 Concordância entre as reações de RT-PCR, PAGE e ELISA

As concordâncias entre os resultados das reações de RT-PCR, visando o gene codificador da NSP5, PAGE e ELISA são apresentadas nas tabelas 2 e 3.

Tabela 2 - Concordância entre os resultados das reações de PAGE e PCR (NSP5) de rotavírus do grupo A

\begin{tabular}{lccc}
\hline & \multicolumn{2}{c}{ PCR - NSP5 } & \\
PAGE & Positivo & Negativo & Total \\
\hline Positivo & 8 & 2 & 10 \\
Negativo & 31 & 70 & 101 \\
Total & 39 & 72 & 111 \\
\hline
\end{tabular}

Tabela 3 - Concordância entre os resultados das reações de ELISA e PCR (NSP5) de rotavírus do grupo A

\begin{tabular}{lccc} 
& \multicolumn{2}{c}{ PCR - NSP5 } & \\
ELISA & Positivo & Negativo & Total \\
\hline Positivo & 4 & 2 & 6 \\
Negativo & 35 & 70 & 105 \\
Total & 39 & 72 & 111 \\
\hline
\end{tabular}

Confrontando-se os resultados gerados pelas técnicas empregadas neste estudo - ELISA, PAGE e RT-PCR (NSP5) - obtiveram-se os seguintes valores de concordância, calculados pelo índice kappa, a um nível de confiança de 95\% (LANDIS; KOCH, 1977; FLEISS, 1981):
a) PAGE $x$ ELISA = 0,33 (baixa concordância)
b) PAGE x RT-PCR = 0,214 (baixa concordância)
c) ELISA x RT-PCR = 0,093 (baixa concordância)

\subsubsection{Caracterização do genotipo $\mathrm{G}$ através de RT-PCR}

Das amostras detectadas no item 5.3.1, foi possível caracterizar o genotipo $\mathrm{G}$ em 8 delas ( $8 / 39$ ou 20,31\%), a saber: $12,15,41,53,55,76,77,79$ (Tabela 4). Foram definidos os genotipos G5 (1/8), G8(6/8) e G11(1/8). 
5.3.4 Detecção de rotavírus por RT-PCR visando o gene codificador da VP7 com primers desenhados no estudo

Os 111 pools de amostras fecais foram adicionalmente analisados com um par de primer visando o gene codificador da VP7 desenhados neste estudo (item 4.6.2.1), foi possível obter outras duas amostras positivas para rotavírus do grupo A, sendo elas ID 7 e 65 (Tabela 4). As amostras tiveram seus genotipos definidos por sequenciamento nucleotídico e análise genética (item 5.4.2).

\subsubsection{Caracterização do genotipo P através de RT-PCR}

Através da reação de "nested" PCR (item 4.6.2) não foi possível caracterizar quaisquer genotipos de rotavírus. Entretanto como foi possível observar os produtos da primeira amplificação de um fragmento do gene codificador da VP4 em 13 amostras (33,33\%) (Tabela 4, campo ID: 1, 3, 4, 7, 28, 41, 46, 53, 64, 65, 77, 104 e 107). As amostras tiveram seus genotipos definidos por sequenciamento nucleotídico e análise genética (item 5.4.3).

\subsubsection{Diagnóstico de rotavírus do grupo D por RT - PCR}

Com relação a PCR visando o gene codificador da VP6 de rotavírus do grupo D, obtiveram-se sete amostras positivas (Tabela 4, campo ID: 38, 47, 60, 103, 105, 106 e 110). As amostras tiveram seus grupos definidos por sequenciamento nucleotídico e análise genética (item 5.4.4). 
Tabela 4 - Resultados dos testes diagnósticos e de genotipagem para rotavírus do grupo A e de PCR para rotavírus do grupo D das amostras de pools de aves do presente estudo (continua) - São Paulo - 2013

\begin{tabular}{|c|c|c|c|c|c|c|c|c|c|}
\hline ID & ELISA & PAGE & $\begin{array}{l}\text { PCR ROTA } \\
\text { A- NSP5 } \\
\text { (SALEM et } \\
\text { al., 2010) }\end{array}$ & $\begin{array}{l}\text { PCR- VP7 } \\
\text { (G) } \\
\text { (GOUVEA } \\
\text { et al., } \\
\text { 1994a) }\end{array}$ & \begin{tabular}{|} 
PCR-VP4 (P) \\
(GOUVEA \\
et al., \\
1994b)
\end{tabular} & $\begin{array}{c}\text { PCR- VP7 } \\
\text { (Desenhado } \\
\text { no estudo) }\end{array}$ & $\begin{array}{c}\text { PCR ROTA D } \\
\text { VP6 } \\
\text { (BEZERRA et } \\
\text { al., 2012) }\end{array}$ & Procedência & Tipo cria ção \\
\hline 1 & $\mathrm{~N}$ & $\mathrm{~N}$ & $\mathrm{P}$ & ND & $\mathrm{P}$ & $\mathrm{N}$ & $\mathrm{N}$ & $\mathrm{NI}$ & $\mathrm{NI}$ \\
\hline 2 & $\mathrm{~N}$ & $\mathrm{~N}$ & $\mathrm{~N}$ & - & - & $\mathrm{N}$ & $\mathrm{N}$ & ES & POSTURA \\
\hline 3 & $\mathrm{~N}$ & $\mathrm{~N}$ & $P$ & ND & $P$ & $\mathrm{~N}$ & $\mathrm{~N}$ & PR & CORTE \\
\hline 4 & $\mathrm{~N}$ & $\mathrm{P}$ & $\mathrm{P}$ & ND & $\mathrm{P}$ & $\mathrm{N}$ & $\mathrm{N}$ & PR & CORTE \\
\hline 5 & $\mathrm{~N}$ & $\mathrm{~N}$ & $\mathrm{P}$ & ND & ND & $\mathrm{N}$ & $\mathrm{N}$ & PR & MATRIZ \\
\hline 6 & $\mathrm{~N}$ & $\mathrm{~N}$ & $\mathrm{~N}$ & - & - & $\mathrm{N}$ & $\mathrm{N}$ & CE & CORTE \\
\hline 7 & $\mathrm{~N}$ & $\mathrm{P}$ & $\mathrm{P}$ & ND & $\mathrm{P}$ & $\mathrm{P}$ & $\mathrm{N}$ & PR & CORTE \\
\hline 8 & $\mathrm{~N}$ & $\mathrm{~N}$ & $\mathrm{~N}$ & - & - & $\mathrm{N}$ & $\mathrm{N}$ & $\mathrm{NI}$ & $\mathrm{NI}$ \\
\hline 9 & $\mathrm{~N}$ & $\mathrm{~N}$ & $\mathrm{~N}$ & - & - & $\mathrm{N}$ & $\mathrm{N}$ & SC & AVós \\
\hline 10 & $\mathrm{~N}$ & $\mathrm{~N}$ & $\mathrm{~N}$ & - & - & $\mathrm{N}$ & $\mathrm{N}$ & SC & AVós \\
\hline 11 & $\mathrm{~N}$ & $\mathrm{~N}$ & $\mathrm{~N}$ & - & - & $\mathrm{N}$ & $\mathrm{N}$ & RS & $\mathrm{NI}$ \\
\hline 12 & $\mathrm{P}$ & $\mathrm{P}$ & $\mathrm{P}$ & G5 & ND & $\mathrm{N}$ & $\mathrm{N}$ & RS & AVÓS \\
\hline 13 & $\mathrm{~N}$ & $\mathrm{~N}$ & $\mathrm{~N}$ & - & - & $\mathrm{N}$ & $\mathrm{N}$ & $\mathrm{RS}$ & CORTE \\
\hline 14 & $\mathrm{~N}$ & $\mathrm{~N}$ & $\mathrm{P}$ & ND & ND & $\mathrm{N}$ & $\mathrm{N}$ & SC & MATRIZ \\
\hline 15 & $\mathrm{~N}$ & $\mathrm{~N}$ & $\mathrm{P}$ & G8 & ND & $\mathrm{N}$ & $\mathrm{N}$ & GO & MATRIZ \\
\hline 16 & $\mathrm{~N}$ & $\mathrm{~N}$ & $\mathrm{~N}$ & - & - & $\mathrm{N}$ & $\mathrm{N}$ & SC & CORTE \\
\hline 17 & $\mathrm{~N}$ & $\mathrm{~N}$ & $\mathrm{~N}$ & - & - & $N$ & $\mathrm{~N}$ & $\mathrm{NI}$ & $\mathrm{NI}$ \\
\hline 18 & $\mathrm{~N}$ & $\mathrm{~N}$ & $\mathrm{~N}$ & - & - & $\mathrm{N}$ & $\mathrm{N}$ & $\mathrm{NI}$ & $\mathrm{NI}$ \\
\hline 19 & $\mathrm{~N}$ & $\mathrm{~N}$ & $\mathrm{~N}$ & - & - & $\mathrm{N}$ & $\mathrm{N}$ & PR & MATRIZ \\
\hline 20 & $\mathrm{P}$ & $\mathrm{N}$ & $\mathrm{P}$ & ND & ND & $\mathrm{N}$ & $\mathrm{N}$ & SC & MATRIZ \\
\hline 21 & $\mathrm{~N}$ & $\mathrm{~N}$ & $\mathrm{~N}$ & - & - & $\mathrm{N}$ & $\mathrm{N}$ & BA & CORTE \\
\hline 22 & $\mathrm{~N}$ & $\mathrm{~N}$ & $\mathrm{~N}$ & - & - & $\mathrm{N}$ & $\mathrm{N}$ & PR & CORTE \\
\hline 23 & $\mathrm{~N}$ & $\mathrm{~N}$ & $\mathrm{~N}$ & - & - & $\mathrm{N}$ & $\mathrm{N}$ & PR & CORTE \\
\hline 24 & $\mathrm{~N}$ & $\mathrm{~N}$ & $\mathrm{~N}$ & - & - & $\mathrm{N}$ & $\mathrm{N}$ & PR & CORTE \\
\hline 25 & $\mathrm{~N}$ & $\mathrm{~N}$ & $\mathrm{~N}$ & - & - & $\mathrm{N}$ & $\mathrm{N}$ & $\mathrm{NI}$ & $\mathrm{NI}$ \\
\hline 26 & $\mathrm{~N}$ & $\mathrm{~N}$ & $\mathrm{~N}$ & - & - & $\mathrm{N}$ & $\mathrm{N}$ & SC & MATRIZ \\
\hline 27 & $\mathrm{~N}$ & $\mathrm{~N}$ & $\mathrm{~N}$ & - & - & $\mathrm{N}$ & $\mathrm{N}$ & GO & MATRIZ \\
\hline 28 & $\mathrm{~N}$ & $\mathrm{~N}$ & $\mathrm{P}$ & ND & $\mathrm{P}$ & $\mathrm{N}$ & $\mathrm{N}$ & $\mathrm{NI}$ & $\mathrm{NI}$ \\
\hline 29 & $\mathrm{~N}$ & $\mathrm{P}$ & $\mathrm{N}$ & ND & ND & $\mathrm{N}$ & $\mathrm{N}$ & $\mathrm{NI}$ & $\mathrm{NI}$ \\
\hline 30 & $\mathrm{~N}$ & $\mathrm{P}$ & $\mathrm{P}$ & ND & ND & $\mathrm{N}$ & $\mathrm{N}$ & SC & MATRIZ \\
\hline 31 & $\mathrm{~N}$ & $\mathrm{~N}$ & $\mathrm{~N}$ & - & - & $\mathrm{N}$ & $\mathrm{N}$ & $\mathrm{NI}$ & $\mathrm{NI}$ \\
\hline 32 & $\mathrm{~N}$ & $\mathrm{P}$ & $\mathrm{P}$ & ND & ND & $\mathrm{N}$ & $\mathrm{N}$ & SC & MATRIZ \\
\hline 33 & $\mathrm{~N}$ & $\mathrm{~N}$ & $\mathrm{~N}$ & - & - & $\mathrm{N}$ & $\mathrm{N}$ & $\mathrm{NI}$ & $\mathrm{NI}$ \\
\hline 34 & $\mathrm{~N}$ & $\mathrm{~N}$ & $\mathrm{~N}$ & - & - & $\mathrm{N}$ & $\mathrm{N}$ & SC & MATRIZ \\
\hline 35 & $\mathrm{~N}$ & $\mathrm{~N}$ & $\mathrm{~N}$ & - & - & $\mathrm{N}$ & $\mathrm{N}$ & $\mathrm{GO}$ & MATRIZ \\
\hline
\end{tabular}


Tabela 4 - Resultados dos testes diagnósticos e de genotipagem para rotavírus do grupo A e de PCR para rotavírus do grupo D das amostras de pools de aves do presente estudo (continuação) - São Paulo 2013

(continuação)

\begin{tabular}{|c|c|c|c|c|c|c|c|c|c|}
\hline ID & ELISA & PAGE & $\begin{array}{l}\text { PCR ROTA } \\
\text { A- NSP5 } \\
\text { (SALEM et } \\
\text { al., 2010) }\end{array}$ & \begin{tabular}{c|c}
$\begin{array}{c}\text { PCR- VP7 } \\
\text { (G) }\end{array}$ & PC \\
(GOUVEA & $(C$ \\
et al., & \\
1994a) &
\end{tabular} & $\begin{array}{c}\text { CR-VP4 (P) } \\
\text { (GOUVEA } \\
\text { et al., } \\
\text { 1994b) }\end{array}$ & $\begin{array}{c}\text { PCR-VP7 } \\
\text { (Desenhado } \\
\text { no estudo) }\end{array}$ & $\begin{array}{c}\text { PCR ROTA D } \\
\text { VP6 } \\
\text { (BEZERRA et } \\
\text { al., 2012) }\end{array}$ & Procedência & Tipo criação \\
\hline 36 & $\mathrm{~N}$ & $\mathrm{~N}$ & $\mathrm{~N}$ & - & - & $\mathrm{N}$ & $N$ & $\mathrm{NI}$ & $\mathrm{NI}$ \\
\hline 37 & $\mathrm{~N}$ & $\mathrm{~N}$ & $\mathrm{~N}$ & - & - & $N$ & $N$ & GO & MATRIZ \\
\hline 38 & $\mathrm{~N}$ & $\mathrm{~N}$ & $\mathrm{~N}$ & - & - & $\mathrm{N}$ & $\mathrm{P}$ & $\mathrm{GO}$ & MATRIZ \\
\hline 39 & $\mathrm{~N}$ & $\mathrm{~N}$ & $\mathrm{~N}$ & - & - & $\mathrm{N}$ & $\mathrm{N}$ & SC & MATRIZ \\
\hline 40 & $\mathrm{~N}$ & $\mathrm{~N}$ & $\mathrm{~N}$ & - & - & $\mathrm{N}$ & $N$ & $\mathrm{NI}$ & $\mathrm{NI}$ \\
\hline 41 & $\mathrm{~N}$ & $\mathrm{~N}$ & $\mathrm{P}$ & $\mathrm{G}[8]$ & $\mathrm{P}[1]$ & $\mathrm{N}$ & $\mathrm{N}$ & $\mathrm{NI}$ & $\mathrm{NI}$ \\
\hline 42 & $\mathrm{~N}$ & $\mathrm{~N}$ & $\mathrm{~N}$ & - & - & $\mathrm{N}$ & $\mathrm{N}$ & SP & CORTE \\
\hline 43 & $\mathrm{~N}$ & $\mathrm{~N}$ & $\mathrm{~N}$ & - & - & $\mathrm{N}$ & $N$ & $\mathrm{NI}$ & $\mathrm{NI}$ \\
\hline 44 & $\mathrm{~N}$ & $\mathrm{~N}$ & $\mathrm{~N}$ & - & - & $\mathrm{N}$ & $\mathrm{N}$ & $\mathrm{NI}$ & $\mathrm{NI}$ \\
\hline 45 & $\mathrm{~N}$ & $\mathrm{~N}$ & $\mathrm{~N}$ & - & - & $\mathrm{N}$ & $N$ & $P R$ & CORTE \\
\hline 46 & $\mathrm{~N}$ & $\mathrm{~N}$ & $\mathrm{P}$ & ND & $P[1]$ & $\mathrm{N}$ & $\mathrm{N}$ & $P R$ & CORTE \\
\hline 47 & $N$ & $\mathrm{~N}$ & $\mathrm{~N}$ & - & - & $\mathrm{N}$ & $\mathrm{P}$ & PR & CORTE \\
\hline 48 & $\mathrm{~N}$ & $\mathrm{~N}$ & $\mathrm{~N}$ & - & - & $\mathrm{N}$ & $\mathrm{N}$ & PR & CORTE \\
\hline 49 & $\mathrm{~N}$ & $\mathrm{~N}$ & $\mathrm{~N}$ & - & - & $\mathrm{N}$ & $\mathrm{N}$ & $P R$ & CORTE \\
\hline 50 & $\mathrm{~N}$ & $\mathrm{~N}$ & $\mathrm{~N}$ & - & - & $\mathrm{N}$ & $\mathrm{N}$ & PR & CORTE \\
\hline 51 & $\mathrm{~N}$ & $\mathrm{~N}$ & $\mathrm{~N}$ & - & - & $\mathrm{N}$ & $N$ & PR & CORTE \\
\hline 52 & $N$ & $\mathrm{~N}$ & $\mathrm{~N}$ & - & - & $\mathrm{N}$ & $\mathrm{N}$ & $S P$ & POEDEIRA \\
\hline 53 & $\mathrm{~N}$ & $\mathrm{~N}$ & $\mathrm{P}$ & $\mathrm{G}[11] \mathrm{G}[5]$ & $P[1]$ & $\mathrm{N}$ & $\mathrm{N}$ & SP & MATRIZ \\
\hline 54 & $N$ & $\mathrm{~N}$ & $\mathrm{~N}$ & - & - & $\mathrm{N}$ & $\mathrm{N}$ & $S P$ & MATRIZ \\
\hline 55 & $\mathrm{~N}$ & $\mathrm{~N}$ & $\mathrm{P}$ & $\mathrm{G}[8]$ & ND & $\mathrm{N}$ & $\mathrm{N}$ & RS & MATRIZ \\
\hline 56 & $\mathrm{~N}$ & $\mathrm{~N}$ & $\mathrm{~N}$ & - & - & $\mathrm{N}$ & $\mathrm{N}$ & RS & MATRIZ \\
\hline 57 & $\mathrm{~N}$ & $\mathrm{~N}$ & $\mathrm{P}$ & ND & ND & $\mathrm{N}$ & $\mathrm{N}$ & RS & MATRIZ \\
\hline 58 & $\mathrm{~N}$ & $\mathrm{~N}$ & $\mathrm{~N}$ & - & - & $\mathrm{N}$ & $\mathrm{N}$ & $\mathrm{NI}$ & $\mathrm{NI}$ \\
\hline 59 & $\mathrm{~N}$ & $\mathrm{~N}$ & $\mathrm{~N}$ & - & - & $\mathrm{N}$ & $\mathrm{N}$ & $\mathrm{NI}$ & $\mathrm{NI}$ \\
\hline 60 & $\mathrm{~N}$ & $\mathrm{~N}$ & $\mathrm{~N}$ & - & - & $\mathrm{N}$ & $\mathrm{P}$ & SP & CORTE \\
\hline 61 & $\mathrm{~N}$ & $\mathrm{~N}$ & $\mathrm{P}$ & ND & ND & $\mathrm{N}$ & $\mathrm{N}$ & SP & CORTE \\
\hline 62 & $\mathrm{~N}$ & $\mathrm{~N}$ & $\mathrm{~N}$ & - & - & $\mathrm{N}$ & $N$ & SP & CORTE \\
\hline 63 & $\mathrm{~N}$ & $\mathrm{~N}$ & $\mathrm{P}$ & ND & ND & $\mathrm{N}$ & $\mathrm{N}$ & SP & CORTE \\
\hline 64 & $\mathrm{~N}$ & $\mathrm{P}$ & $\mathrm{P}$ & ND & $P[1]$ & $\mathrm{N}$ & $\mathrm{N}$ & SP & CORTE \\
\hline 65 & $\mathrm{~N}$ & $\mathrm{~N}$ & $P$ & $\mathrm{G}[5]$ & $P$ & $P$ & $N$ & $P R$ & CORTE \\
\hline 66 & $\mathrm{~N}$ & $\mathrm{~N}$ & $\mathrm{~N}$ & - & - & $\mathrm{N}$ & $\mathrm{N}$ & $P R$ & CORTE \\
\hline 67 & $\mathrm{~N}$ & $\mathrm{~N}$ & $\mathrm{~N}$ & - & - & $\mathrm{N}$ & $\mathrm{N}$ & PR & CORTE \\
\hline 68 & $\mathrm{~N}$ & $\mathrm{~N}$ & $\mathrm{~N}$ & - & - & $\mathrm{N}$ & $\mathrm{N}$ & $P R$ & CORTE \\
\hline 69 & $\mathrm{~N}$ & $\mathrm{~N}$ & $\mathrm{~N}$ & - & - & $\mathrm{N}$ & $\mathrm{N}$ & PR & CORTE \\
\hline 70 & $\mathrm{~N}$ & $\mathrm{~N}$ & $\mathrm{~N}$ & - & - & $\mathrm{N}$ & $\mathrm{N}$ & SP & POEDEIRA \\
\hline 71 & $\mathrm{~N}$ & $\mathrm{~N}$ & $\mathrm{P}$ & ND & ND & $\mathrm{N}$ & $\mathrm{N}$ & SP & POEDEIRA \\
\hline 72 & $\mathrm{~N}$ & $\mathrm{~N}$ & $\mathrm{~N}$ & - & - & $\mathrm{N}$ & $\mathrm{N}$ & $S P$ & POEDEIRA \\
\hline 73 & $\mathrm{~N}$ & $\mathrm{~N}$ & $\mathrm{~N}$ & - & - & $\mathrm{N}$ & $\mathrm{N}$ & SP & POEDEIRA \\
\hline 74 & $\mathrm{~N}$ & $\mathrm{~N}$ & $\mathrm{~N}$ & - & - & $\mathrm{N}$ & $\mathrm{N}$ & $S P$ & POEDEIRA \\
\hline 75 & $\mathrm{~N}$ & $\mathrm{~N}$ & $\mathrm{~N}$ & - & - & $\mathrm{N}$ & $\mathrm{N}$ & SP & POEDEIRA \\
\hline 76 & $\mathrm{~N}$ & $\mathrm{~N}$ & $\mathrm{P}$ & $\mathrm{G}[8]$ & ND & $\mathrm{N}$ & $\mathrm{N}$ & SP & POEDEIRA \\
\hline 77 & $\mathrm{~N}$ & $\mathrm{~N}$ & $\mathrm{P}$ & $\mathrm{G}[8]$ & $P[1]$ & $\mathrm{N}$ & $\mathrm{N}$ & SP & POEDEIRA \\
\hline 78 & $\mathrm{~N}$ & $\mathrm{~N}$ & $\mathrm{P}$ & ND & ND & $\mathrm{N}$ & $\mathrm{N}$ & SP & POEDEIRA \\
\hline
\end{tabular}


Tabela 4 - Resultados dos testes diagnósticos e de genotipagem para rotavírus do grupo A e de PCR para rotavírus do grupo D das amostras de pools de aves do presente estudo (conclusão) - São Paulo 2013

(conclusão)

\begin{tabular}{|c|c|c|c|c|c|c|c|c|c|}
\hline ID & ELISA & PAGE & $\begin{array}{l}\text { PCR ROTA } \\
\text { A- NSP5 } \\
\text { (SALEM et } \\
\text { al., 2010) }\end{array}$ & $\begin{array}{c}\text { PCR- VP7 } \\
\text { (G) } \\
\text { (GOUVEA } \\
\text { et al., } \\
\text { 1994a) } \\
\end{array}$ & $\begin{array}{c}\text { PCR-VP4 (P) } \\
\text { (GOUVEA } \\
\text { et al., } \\
\text { 1994b) }\end{array}$ & $\begin{array}{c}\text { PCR-VP7 } \\
\text { (Desenhado } \\
\text { no estudo) }\end{array}$ & $\begin{array}{c}\text { PCR ROTA D } \\
\text { VP6 } \\
\text { (BEZERRA et } \\
\text { al., 2012) }\end{array}$ & Procedência & Tipo cria ção \\
\hline 79 & $\mathrm{~N}$ & $\mathrm{~N}$ & P & $\mathrm{G}[8]$ & ND & $\mathrm{N}$ & $\mathrm{N}$ & SP & POEDEIRA \\
\hline 80 & $\mathrm{~N}$ & $\mathrm{~N}$ & $\mathrm{P}$ & ND & ND & $\mathrm{N}$ & $\mathrm{N}$ & $S P$ & POEDEIRA \\
\hline 81 & $\mathrm{~N}$ & $\mathrm{~N}$ & $\mathrm{~N}$ & - & - & $\mathrm{N}$ & $\mathrm{N}$ & SP & POEDEIRA \\
\hline 82 & $\mathrm{~N}$ & $\mathrm{~N}$ & P & ND & ND & $\mathrm{N}$ & $\mathrm{N}$ & $S P$ & CORTE \\
\hline 83 & $\mathrm{~N}$ & $\mathrm{~N}$ & P & ND & ND & $\mathrm{N}$ & $\mathrm{N}$ & SP & CORTE \\
\hline 84 & $\mathrm{~N}$ & $\mathrm{~N}$ & P & ND & ND & $\mathrm{N}$ & $\mathrm{N}$ & SP & CORTE \\
\hline 85 & $\mathrm{~N}$ & P & $\mathrm{N}$ & - & - & $\mathrm{N}$ & $\mathrm{N}$ & SP & CORTE \\
\hline 86 & $\mathrm{~N}$ & $\mathrm{~N}$ & $\mathrm{~N}$ & - & - & $\mathrm{N}$ & $\mathrm{N}$ & $S P$ & CORTE \\
\hline 87 & $\mathrm{~N}$ & $\mathrm{~N}$ & P & ND & ND & $\mathrm{N}$ & $\mathrm{N}$ & $S P$ & CORTE \\
\hline 88 & P & $\mathrm{P}$ & P & ND & ND & $\mathrm{N}$ & $\mathrm{N}$ & SP & CORTE \\
\hline 89 & $\mathrm{~N}$ & $\mathrm{~N}$ & $\mathrm{~N}$ & - & - & $\mathrm{N}$ & $\mathrm{N}$ & SP & CORTE \\
\hline 90 & $\mathrm{~N}$ & $\mathrm{~N}$ & $\mathrm{~N}$ & - & - & $\mathrm{N}$ & $\mathrm{N}$ & SP & CORTE \\
\hline 91 & $\mathrm{~N}$ & $\mathrm{~N}$ & $\mathrm{~N}$ & - & - & $\mathrm{N}$ & $\mathrm{N}$ & $S P$ & CORTE \\
\hline 92 & $\mathrm{~N}$ & $\mathrm{~N}$ & P & ND & ND & $\mathrm{N}$ & $\mathrm{N}$ & $S P$ & CORTE \\
\hline 93 & $\mathrm{~N}$ & $\mathrm{~N}$ & $\mathrm{~N}$ & - & - & $\mathrm{N}$ & $\mathrm{N}$ & $S P$ & CORTE \\
\hline 94 & $\mathrm{~N}$ & $\mathrm{~N}$ & $\mathrm{P}$ & ND & ND & $\mathrm{N}$ & $\mathrm{N}$ & $S P$ & CORTE \\
\hline 95 & $\mathrm{~N}$ & $\mathrm{~N}$ & $\mathrm{~N}$ & - & - & $\mathrm{N}$ & $\mathrm{N}$ & $S P$ & CORTE \\
\hline 96 & $\mathrm{P}$ & $\mathrm{N}$ & $\mathrm{N}$ & ND & ND & $\mathrm{N}$ & $\mathrm{N}$ & $S P$ & CORTE \\
\hline 97 & $\mathrm{~N}$ & $\mathrm{~N}$ & $\mathrm{P}$ & ND & ND & $\mathrm{N}$ & $\mathrm{N}$ & $S P$ & CORTE \\
\hline 98 & $\mathrm{~N}$ & $\mathrm{~N}$ & $\mathrm{~N}$ & - & - & $\mathrm{N}$ & $\mathrm{N}$ & SP & CORTE \\
\hline 99 & $\mathrm{~N}$ & $\mathrm{~N}$ & $\mathrm{~N}$ & - & - & $\mathrm{N}$ & $\mathrm{N}$ & SP & CORTE \\
\hline 100 & $\mathrm{~N}$ & $\mathrm{~N}$ & $\mathrm{~N}$ & - & - & $\mathrm{N}$ & $\mathrm{N}$ & SP & CORTE \\
\hline 101 & $\mathrm{~N}$ & $\mathrm{~N}$ & $P$ & ND & ND & $\mathrm{N}$ & $N$ & SP & CORTE \\
\hline 102 & $\mathrm{~N}$ & $\mathrm{~N}$ & $\mathrm{~N}$ & - & - & $\mathrm{N}$ & $\mathrm{N}$ & SP & CORTE \\
\hline 103 & $\mathrm{~N}$ & $\mathrm{~N}$ & $\mathrm{~N}$ & - & - & $\mathrm{N}$ & P & $S P$ & CORTE \\
\hline 104 & P & $\mathrm{N}$ & $N$ & ND & $P[1]$ & $N$ & $\mathrm{~N}$ & $S P$ & CORTE \\
\hline 105 & $\mathrm{~N}$ & $\mathrm{~N}$ & $\mathrm{~N}$ & - & - & $\mathrm{N}$ & P & $S P$ & CORTE \\
\hline 106 & $\mathrm{~N}$ & $\mathrm{~N}$ & $\mathrm{~N}$ & - & - & $\mathrm{N}$ & P & SP & CORTE \\
\hline 107 & $\mathrm{~N}$ & $\mathrm{~N}$ & P & ND & $P[1]$ & $\mathrm{N}$ & $\mathrm{N}$ & $S P$ & CORTE \\
\hline 108 & $\mathrm{~N}$ & $\mathrm{~N}$ & P & ND & ND & $N$ & $\mathrm{~N}$ & $S P$ & CORTE \\
\hline 109 & $\mathrm{~N}$ & $\mathrm{~N}$ & $\mathrm{~N}$ & - & - & $\mathrm{N}$ & $\mathrm{N}$ & SP & CORTE \\
\hline 110 & $\mathrm{~N}$ & $\mathrm{~N}$ & $\mathrm{~N}$ & - & - & $\mathrm{N}$ & P & $S P$ & CORTE \\
\hline 111 & P & P & P & ND & ND & $N$ & $\mathrm{~N}$ & $S P$ & CORTE \\
\hline
\end{tabular}




\subsection{Reação de sequenciamento nucleotídico}

Neste tópico serão apresentados os resultados das reações de sequenciamento nucleotídico realizadas neste estudo.

5.4.1 Confirmação das RT-PCR visando o gene codificador da NSP5

Os "amplicons" de 3 amostras (item 5.3.1), também positivas por PAGE e ELISA, foram adicionalmente sequenciados visando confirmar a especificidade da reação de RT-PCR (NSP5), cujas sequências estão apresentadas no Anexo A.

Considerando que as sequências parciais apresentaram $100 \%$ de identidade nucleotídica com diferentes amostras de rotavírus do grupo A, através de consulta ao serviço BLAST-n.

\subsubsection{Caracterização de genotipos $\mathrm{G}$}

Foi possível obter sequências parciais de duas amostras positivas pela reação de PCR visando o gene VP7, de rotavírus do grupo A, realizada com os primers desenhados no decorrer do projeto (item 5.3.3).

O genotipo definido a partir da inferência filogenética da VP7 foi G19 (item 5.5.1).

As sequências de VP7 obtidas no estudo estão representadas no quadro 5 de acordo com a identificação da amostra, estado e tipo de criação; tamanho do fragmento do gene sequenciado e número de acesso GenBank. 
Quadro 5 - Relação das amostras de campo positivas para rotavírus do grupo A, com sequenciamento parcial do gene codificador da VP7, de acordo com estado, tipo de criação e número de acesso GenBank - São Paulo - 2013

\begin{tabular}{|c|c|c|c|}
\hline Amostra/ ID & Estado & $\begin{array}{c}\text { Tipo de } \\
\text { Criação }\end{array}$ & $\begin{array}{c}\text { Número de Acesso } \\
\text { GenBank }\end{array}$ \\
\hline USPARV05/ 7 & PR & Corte & KC962122 \\
USPARV06/ 65 & PR & Corte & KC962123 \\
\hline
\end{tabular}

Fonte: Beserra (2013)

\subsubsection{Caracterização de genotipos $\mathrm{P}$}

Com relação ao sequenciamento do gene codificador da proteína VP4 de rotavírus do grupo A, foi possível obter oito sequências parciais (8/13) a partir dos produtos da primeira amplificação do gene (item 5.3.4).

O genotipo definido a partir da inferência filogenética da VP4 foi P[31] (item 5.5.2).

As sequências de VP4 obtidas no estudo estão representadas no quadro 6 de acordo com a identificação da amostra, estado e tipo de criação; tamanho do fragmento do gene sequenciado e número de acesso GenBank.

Quadro 6 - Relação das amostras de campo positivas para rotavírus do grupo A, com sequenciamento parcial do gene codificador da VP4, de acordo com estado, tipo de criação e número de acesso GenBank - São Paulo - 2013

\begin{tabular}{|c|c|c|c|}
\hline Amostra/ ID & Estado & Tipo de Criação & $\begin{array}{c}\text { Número de Acesso } \\
\text { VP4 }\end{array}$ \\
\hline USPARV01/ 46 & PR & Corte & KC962114 \\
USPARV02/ 1 & NI & NI & KC962115 \\
USPARV03/ 103 & SP & Corte & KC962116 \\
USPARV04/ 106 & SP & Corte & KC962117 \\
USPARV05/ 7 & PR & Corte & KC962118 \\
USPARV06/ 65 & PR & Corte & KC962119 \\
USPARV07/ 4 & PR & Corte & KC962120 \\
USPARV08/ 3 & PR & Corte & KC962121 \\
\hline
\end{tabular}

NI: Amostras em que não foi possível identificar estado e tipo de criação de origem.

Fonte: Beserra (2013) 
5.4.4 Confirmação de rotavírus do grupo D

Foi possível obter quatro sequências parciais das sete amostras positivas por PCR visando o gene codificador da VP6 de rotavírus do grupo D, tendo sido confirmado pela inferência filogenética (item 5.5.3)

As sequências de VP6 obtidas no estudo estão representadas no quadro 7 de acordo com a identificação da amostra, estado e tipo de criação; tamanho do fragmento do gene sequenciado e número de acesso GenBank.

Quadro 7- Relação das amostras de campo positivas para rotavírus do grupo D, com sequenciamento parcial do gene codificador da VP6, de acordo com estado, tipo de criação e número de acesso GenBank - São Paulo - 2013

\begin{tabular}{|c|c|c|c|}
\hline Amostra/ ID & Estado & Tipo de Criação & $\begin{array}{c}\text { Número de Acesso } \\
\text { VP6 (Rota D) }\end{array}$ \\
\hline AVRVBR1/ 38 & GO & Matrizeiro & KC689306 \\
AVRVBR2/ 47 & PR & Corte & KC689307 \\
AVRVBR3/ 103 & SP & Corte & KC689308 \\
AVRVBR4/ 106 & SP & Corte & KC689306 \\
\hline
\end{tabular}

Fonte: Beserra (2013)

\subsection{Análise das sequências}

Neste tópico serão apresentadas as inferências filogenéticas realizadas neste estudo.

\subsubsection{Genotipos G}

A inferência filogenética referente a um fragmento parcial (862 nt) dos nucleotídeos codificadores da proteína VP7 dos rotavírus do grupo A detectados no presente estudo 
juntamente com sequências representativas dos demais genotipos recuperadas do Genbank estão apresentadas na figura 2. Os números próximos a cada nó representam os valores de "bootstrap" (1.000 repetições) e a escala representa o número de substituições/sítio. A escala representa o número de substituições/sítio. Os triângulos representam as sequências definidas no presente estudo. 
Figura 2 - Árvore filogenética construída com o método de neighbor-joining através do modelo de substituição maximum composite likelihood (Software Mega v. 5.2) para a região parcial do gene codificador da proteína VP7 dos rotavírus. As amostras apresentam a identificação "accession number"/ hospedeiro / amostra / genotipo VP7. Os números próximos a cada nó representam os valores de 1.000 repetições de "bootstrap", tendo sido demonstrados apenas aqueles superiores a 70\%. A escala representa o número de substituições/sítio. Os triângulos representam as sequências definidas no presente estudo São Paulo - 2013

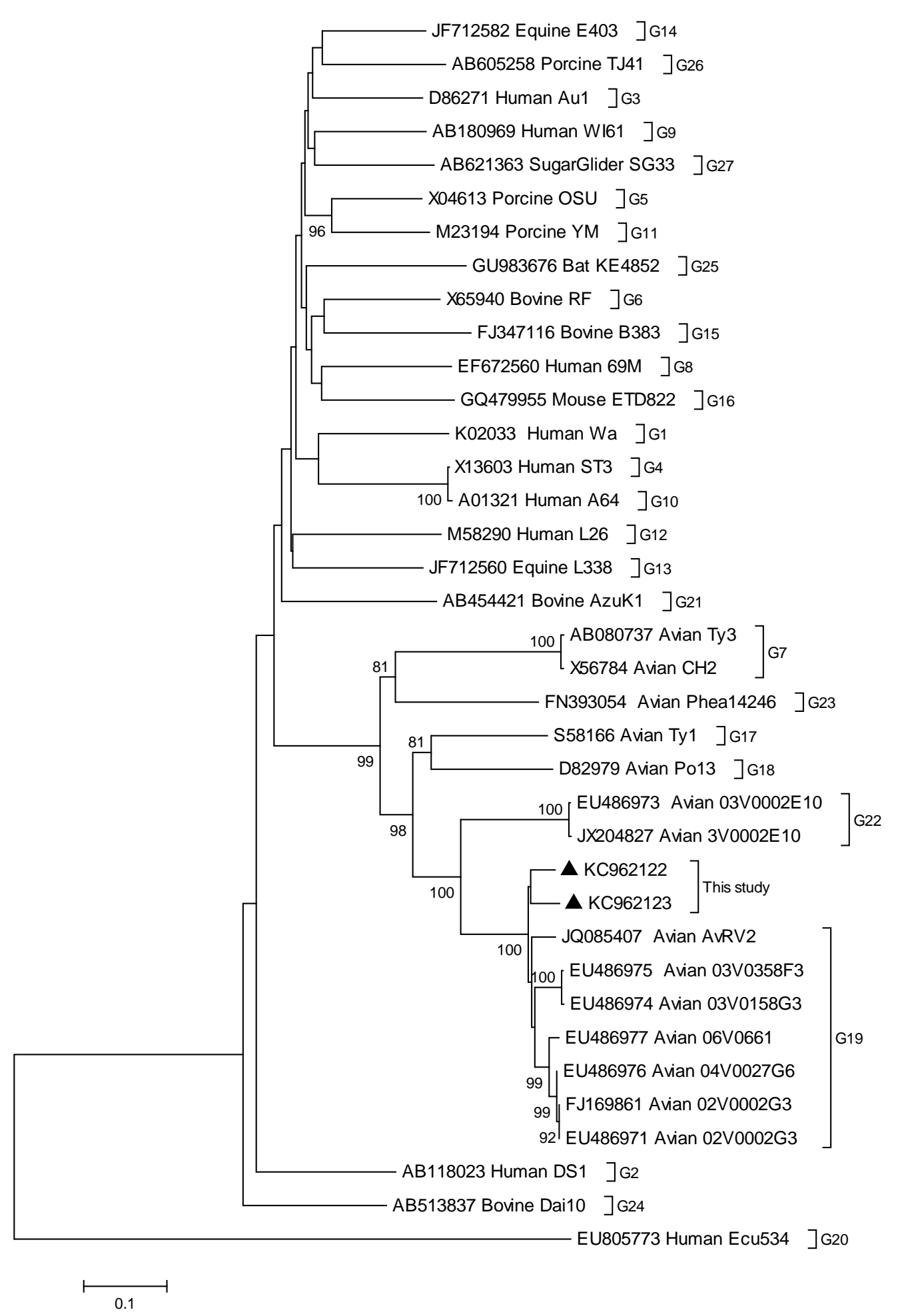


5.5.2 Genotipos P

A inferência filogenética referente a um fragmento parcial (644 nt) dos nucleotídeos codificadores da proteína VP4 dos rotavírus do grupo A detectados no presente estudo juntamente com sequências representativas dos demais genotipos recuperadas do Genbank estão apresentadas na figura 3. Os números próximos a cada nó representam os valores de "bootstrap" (1.000 repetições) e a escala representa o número de substituições/sítio. A escala representa o número de substituições/sítio. Os triângulos representam as sequências definidas no presente estudo. 
Figura 3 - Árvore filogenética construída com o método de neighbor-joining através do modelo de substituição maximum composite likelihood (Software Mega v. 5.2) para a região parcial do gene codificador da proteína VP4 dos rotavírus. As amostras apresentam a identificação "accession number"/ hospedeiro / amostra / genotipo VP4. Os números próximos a cada nó representam os valores de 1000 repetições de bootstrap, tendo sido demonstrados apenas aqueles superiores a 70\%. A escala representa o número de substituições/sítio. Os triângulos representam as sequências definidas no presente estudo -

São Paulo - 2013

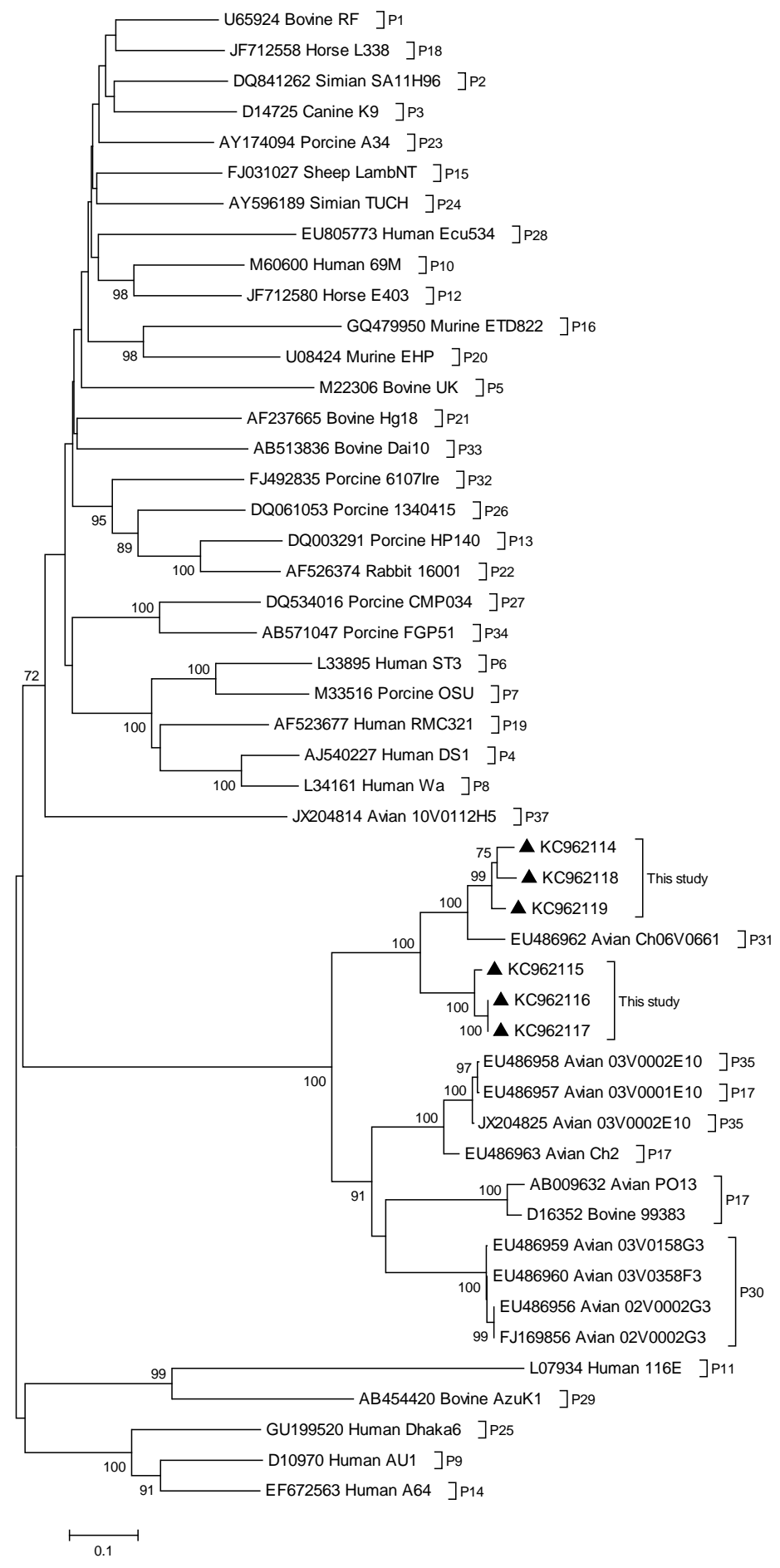




\subsubsection{Rotavírus D}

A inferência filogenética referente a um fragmento parcial dos nucleotídeos codificadores da proteína VP6 dos rotavírus do grupo D detectados no presente estudo juntamente com sequências representativas dos demais grupos recuperadas do Genbank estão apresentadas na figura 4. Os números próximos a cada nó representam os valores de "bootstrap" (1.000 repetições) e a escala representa o número de substituições/sítio. Os triângulos representam as sequências definidas no presente estudo. 
Figura 4 - Árvore genealógica referente ao fragmento parcial dos nucleotídeos codificadores da proteína VP6 dos rotavírus do grupo D detectados no presente estudo juntamente com sequências representativas dos demais grupos definidos recuperadas do Genbank estão apresentadas na figura 11. Os números próximos a cada nó representam os valores de "bootstrap" (1.000 repetições) e a escala representa o número de substituições/sítio. Os triângulos representam as sequências definidas no presente estudo São Paulo - 2013

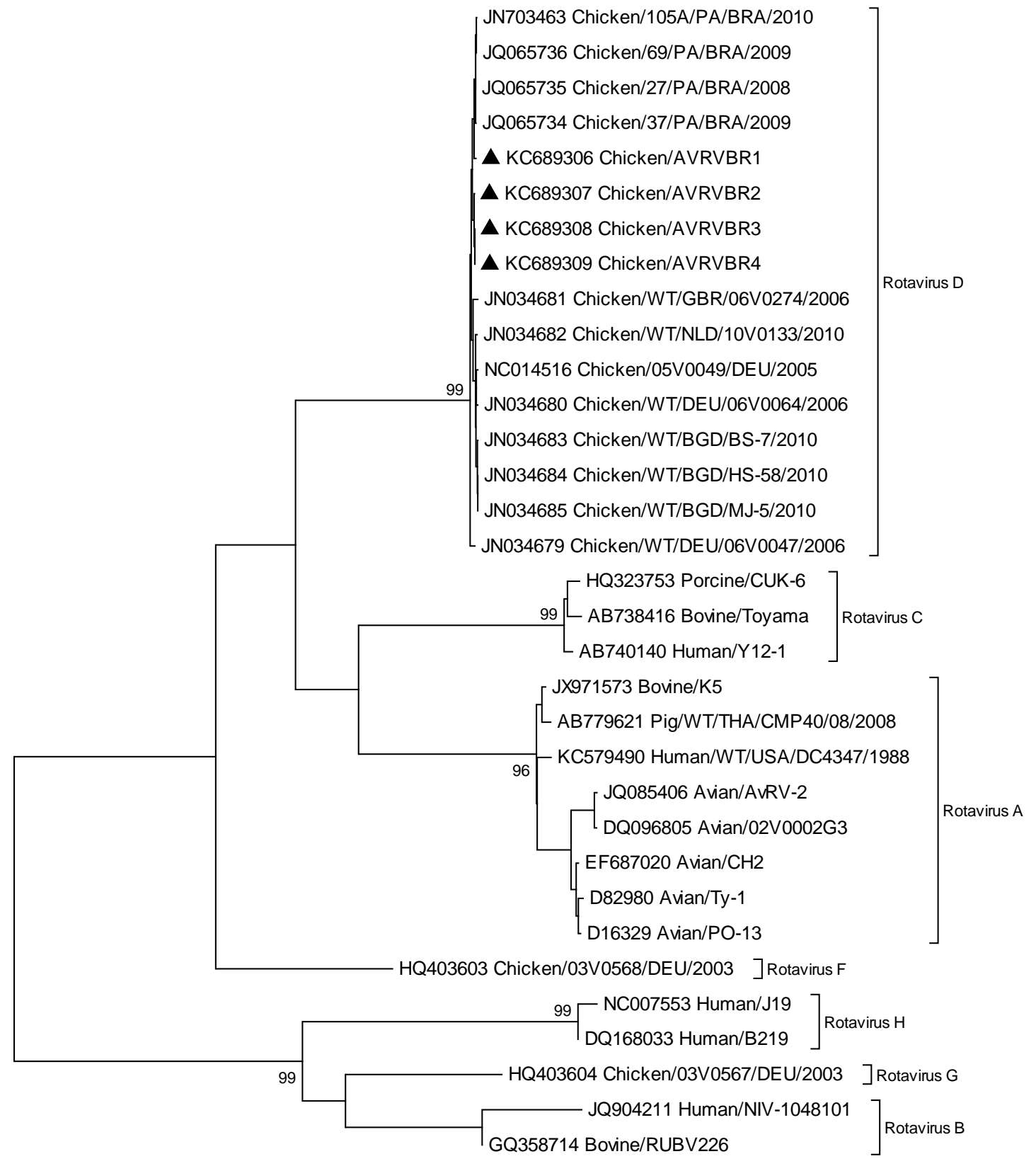




\subsection{Alinhamento das sequências}

$\mathrm{Na}$ figura 5 encontra-se representado o alinhamento de nucleotídeos do gene codificador da VP7 de rotavírus do grupo A referente às amostras geradas no presente estudo, identificadas como KC962122 e KC962122, tomando-se como referência a amostra Ch03V0358F3 (número de acesso EU486975). 
Figura 5 - Alinhamento do fragmento parcial do gene codificador da VP7 de rotavírus do grupo A em aves gerados no presente estudo - São Paulo - 2013

EU486975 Ch-03v0358F3
KC962122
KC962123
EU486975 Ch-03V0358F3
KC962122
KC962123
EU486975 Ch-03V0358F3
KC962122
KC962123
EU486975 Ch-03v0358F3
KC962122
KC962123

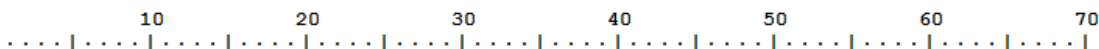
ATGTATAGTACTGAATGTACTATCCTTTCTATTGAGATAATATTCTATTTTATTATAGTACTATTGATTT A $\sim \sim \sim \ldots \ldots \ldots \ldots \ldots \ldots \ldots$. . . . . . . . . . . . (

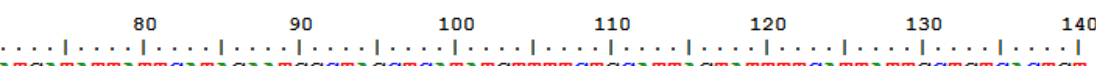
ATGATATTATTCATAGAATGGCTAGTCATATGTTTCTGCATTAGTATTTTCATTATTGCTGTCACTGT

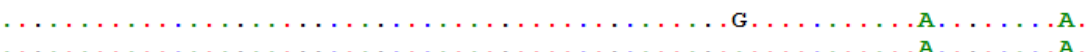

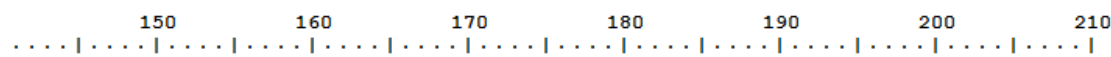
TCTACCACGTTGTCATGCTCAAAATTATGGGGTTAATGTTCCAATCACAGGATCATTAGACGTTACTATA

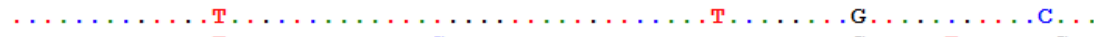
. $\begin{array}{rrrrrrr}220 & 230 & 240 & 250 & 260 & 270 & 280\end{array}$ CAGATCAAACGGTTGÄACAATTGGACTAACGTCAACTTTGTGTTTATATTATCCAACGGAAGCATCA

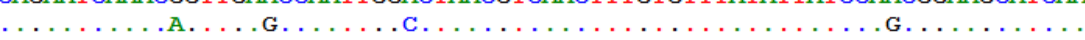
… . . . . . . . . . . . . . . . . .

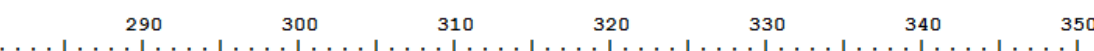
CAGAAATAGCTGATACTGAATGGAAGCAGACAATAAGCCAGTTATTTTTAACCAAGGGGTGGCCAACGAC . . . . . . . . . . . . . . . . . . . . . . .

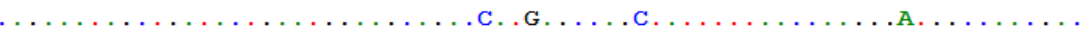

EU486975 Ch-03V0358F3 KC962122

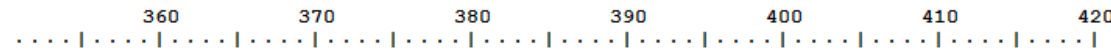
TTCGATTTATTTTAATGAGTATCAAGATTTACAAACGTTTTCGATAAATCAAGTATAAATTGTGATTAC

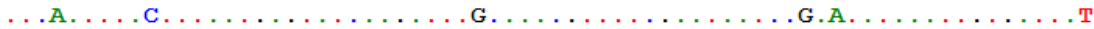

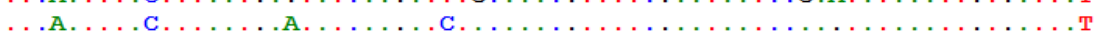
KC962123

EU486975 Ch-03V0358F3

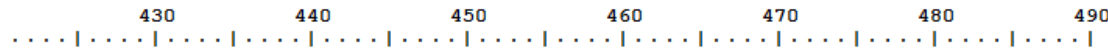
AATATAATACTAATAAAATATGATGGAAATCAAGGGTAGACATTTCAGAAATTGCTGAACTGCTTTTAT

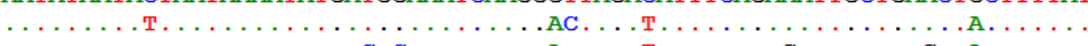
KC962122 KC962123

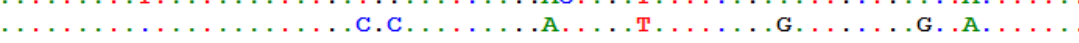

EU486975 Ch-03V0358F3 KC962122 $\begin{array}{llllll}500 & 510 & 520 & 530 & 540 & 550\end{array}$ ACGAATGGCTATGTAATGAAATGGATATTAGTTTATATTATTATCAACAGACCTCAGAGGCTAATAAATG

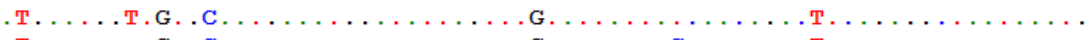

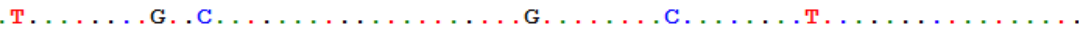

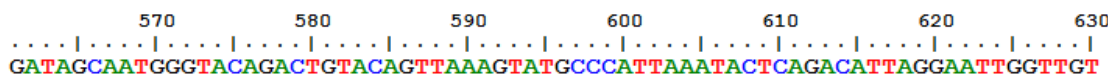
EU486975 Ch-03V0358F3 KC962122

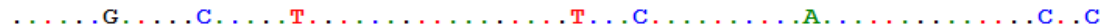
$\ldots \ldots$. . . . . . . . . . . . . . . . .

EU486975 Ch-03V0358F3

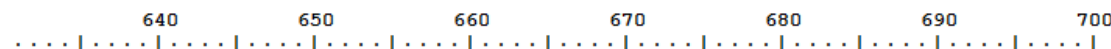

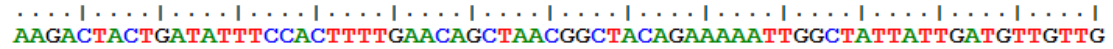

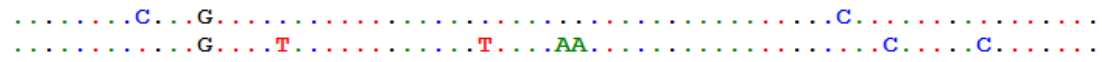
KC962122 710
720 ACGGCGTTAGCCATAAGATAGATTATACCGTAACGACTTGTAACGTTAAGAATTGTATGCGACTAAATCA

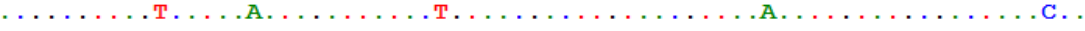

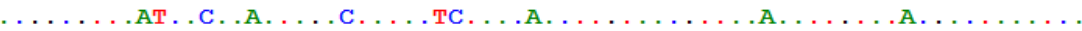
KC962122 KC96218

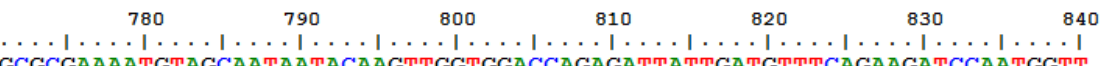
EU486975 Ch-03V0358F3 KC962122

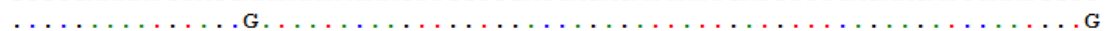

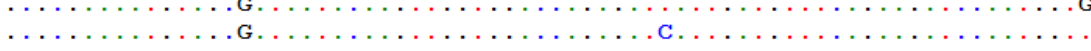
850
$0 . \ldots$ EU486975 Ch-03V0358F3 KC962122 GTACCAAAAATGCAACGCGTAACTAGAATTAATTGGAAAAGATGGTGGCAAGTATTTTATACTATTGTCG .G. . . . . . G. . .G. . . . . . . . 
Na figura 6 encontra-se representado o alinhamento das sequências traduzidas para aminoácidos do gene codificador da VP7 de rotavírus do grupo A referente às amostras geradas no presente estudo, identificadas como KC962122 e KC962122, tomando-se como referência a amostra Ch-03V0358F3 (número de acesso EU486975).

Figura 6 - Alinhamento do da sequência traduzida para aminoácidos do gene codificador da VP7 de rotavírus do grupo A em aves gerados no presente estudo. O quadro em preto representa parte do domínio hidrofóbico da proteína - São Paulo - 2013

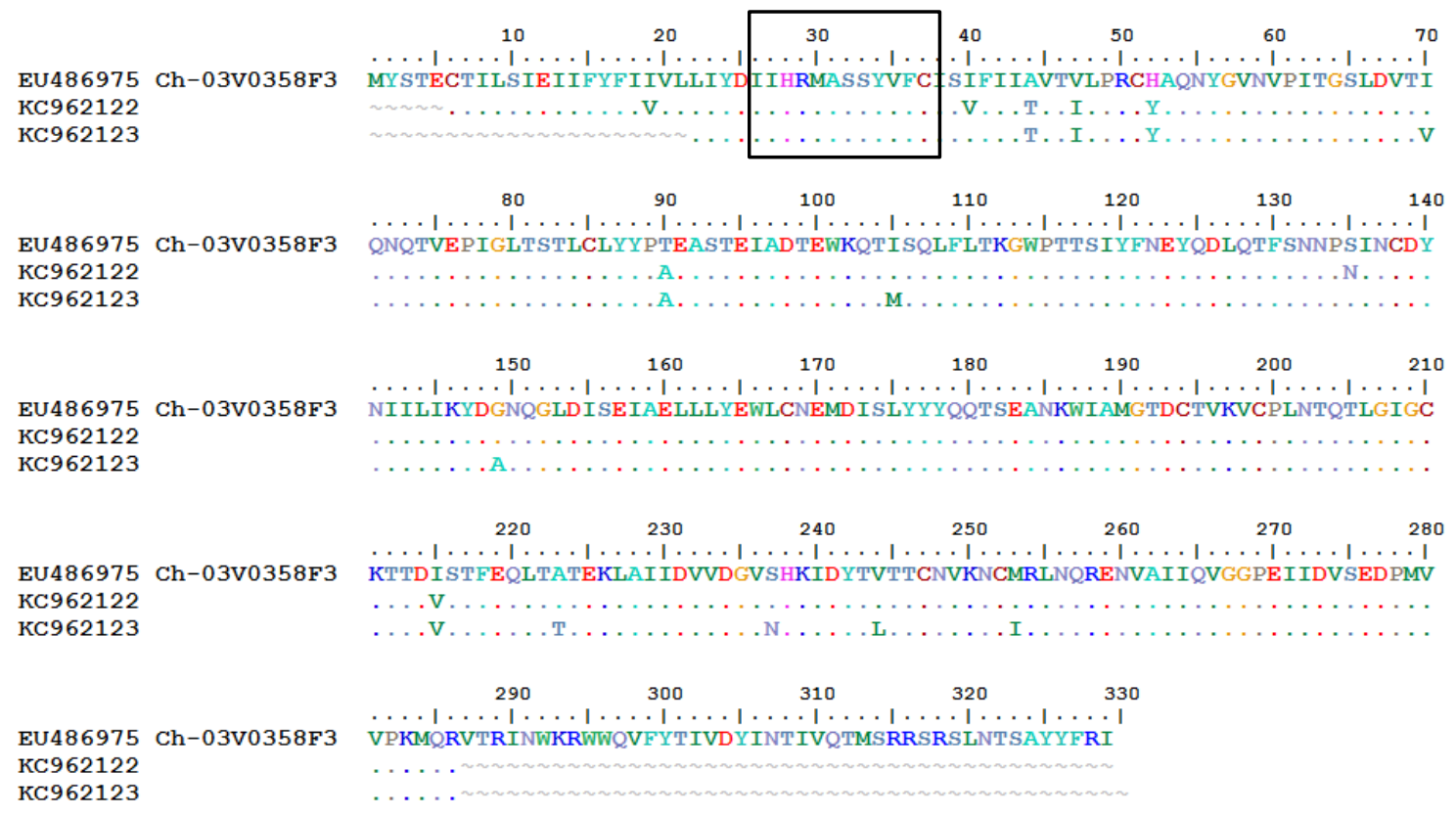

Fonte: Beserra (2013)

$\mathrm{Na}$ figura 7 encontra-se representado o alinhamento das sequências traduzidas para aminoácidos do gene codificador da VP4 de rotavírus do grupo A referente às amostras geradas no presente estudo, identificadas como KC962114 a KC962121, tomando-se como referência a amostra Ch-06V0661 (número de acesso EU486962). 
Figura 7 - Alinhamento do fragmento parcial do gene codificador da VP4 de rotavírus do grupo A em aves gerados no presente estudo - São Paulo - 2013

(continua)

EU486962 Ch06v0661
KC962114
KC962115
KC962116
KC962117
KC962119

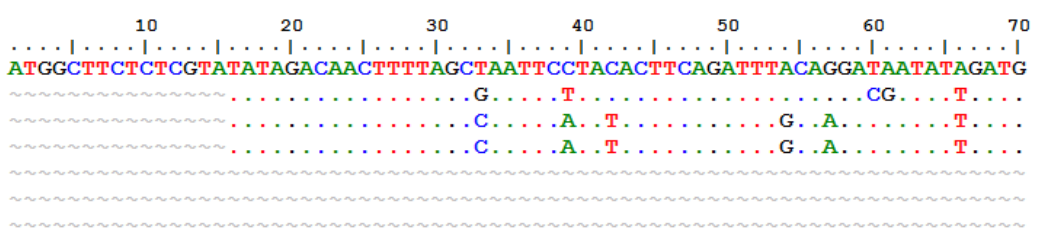

EU486962 Ch06v0661

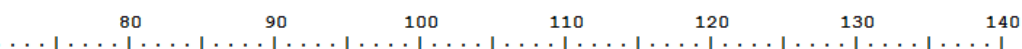
KU486962 ATATTTCTGCTGAAAAAACTCAAGGAGTAACGATTAATCCGGGACCGTTCGCTCAAACAGGTTATGCGCC KC962115 KC962116 KC962117 KC962118 KC962119

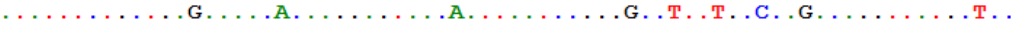

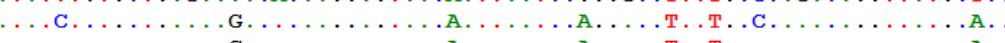

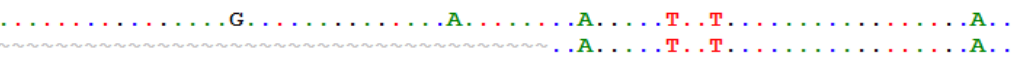

EU486962 Ch06V0661 KC962114 KC962115 KC962116

KC962117

KC962118

KC962119

$\begin{array}{rrrrrr}150 & 160 & 170 & 180 & 190 & 200\end{array}$

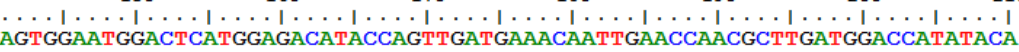

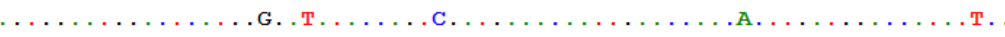
. А. . . . . . . . . . .

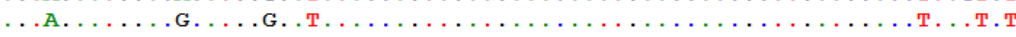

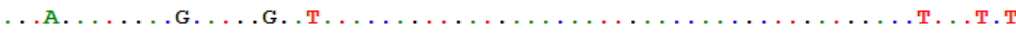

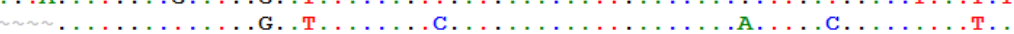
$\sim \sim \ldots$. . . . . . . . . . . . . . . . . . . . . . .

EU486962 Ch06V0661

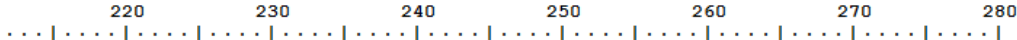
KC962114 GCTTCATCAATTGTAATTCAGCCACAATATTGGATATTAGTGAATCCAACAAATCAGAACGTCGTGATTG KC962114

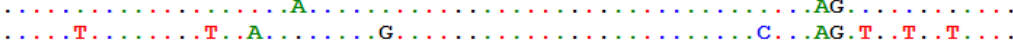

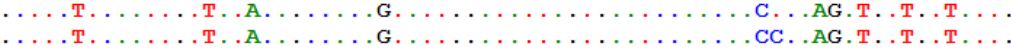

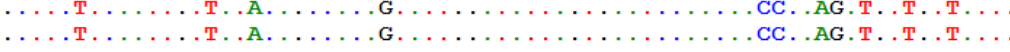

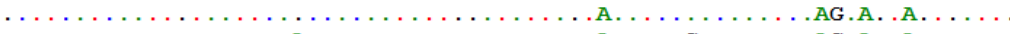
KC962117 KC962118 KC962119

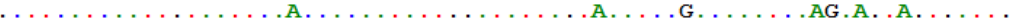

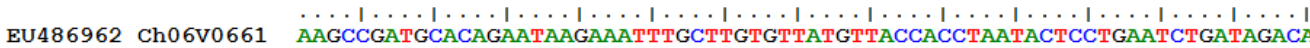

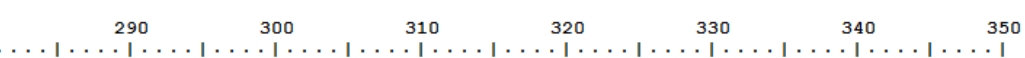
KC962114 KC962115 KC962116 KC962117 KC962118 KC962119

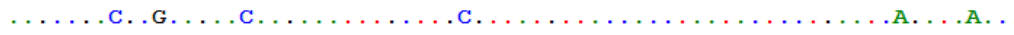

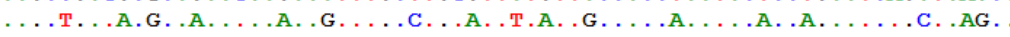

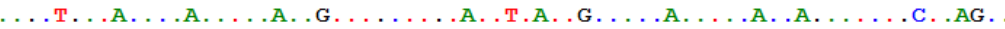

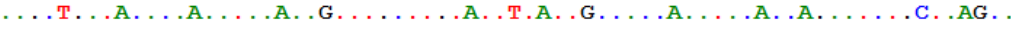

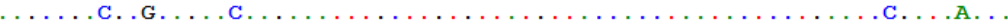

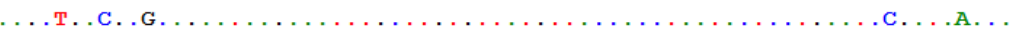

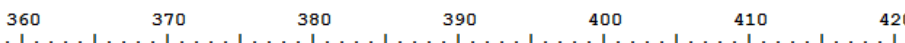
EU486962 Ch06v0661 GTATACGATATTAGGGAAACAAATAACGATTAGATTAGGAAATACTGATACAGTGAATTATAAATTTTGC KC962114 KC962115 KC962116 KC962117 KC962119

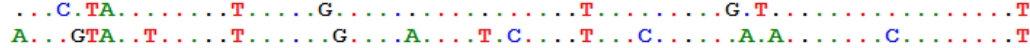

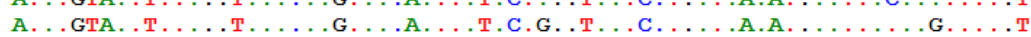

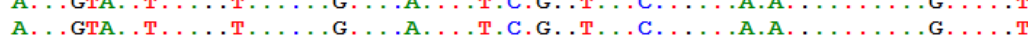

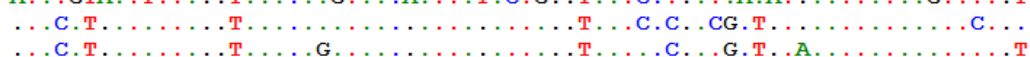
EU486962 Ch06V0661

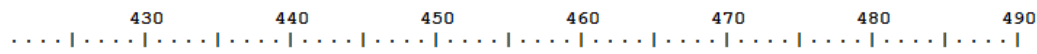
GACTTATTGAGTAATGATGGAATAACTTACACAAAATCAATAGAGTTAATCACTCCGCATCGTTTAAATG

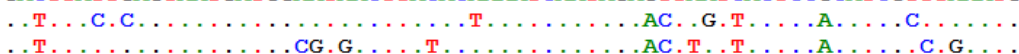

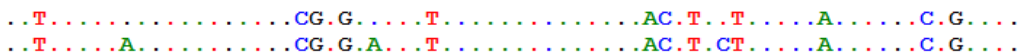

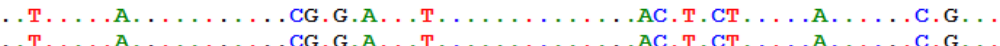

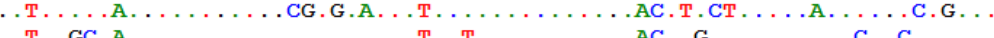
T. GC.A. KC962118 KC962119

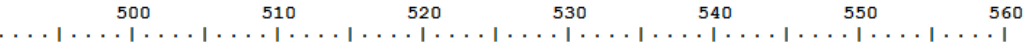
EU486962 Ch06V0661 СATTTATGAAAGATGCTGGTAAATTGTATGCATATAGTGGTACTGTACCAACAATAAAAAAAGAATATCA KC962114

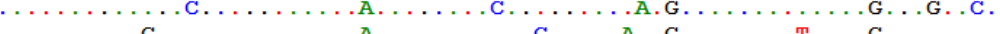
KC962115 KC962116 KC962117 KC962118 KC962119

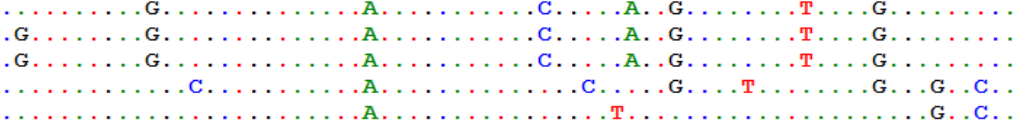

Fonte: Beserra (2013) 
Figura 7 - Alinhamento do fragmento parcial do gene codificador da VP4 de rotavírus do grupo A em aves gerados no presente estudo - São Paulo - 2013

(conclusão)

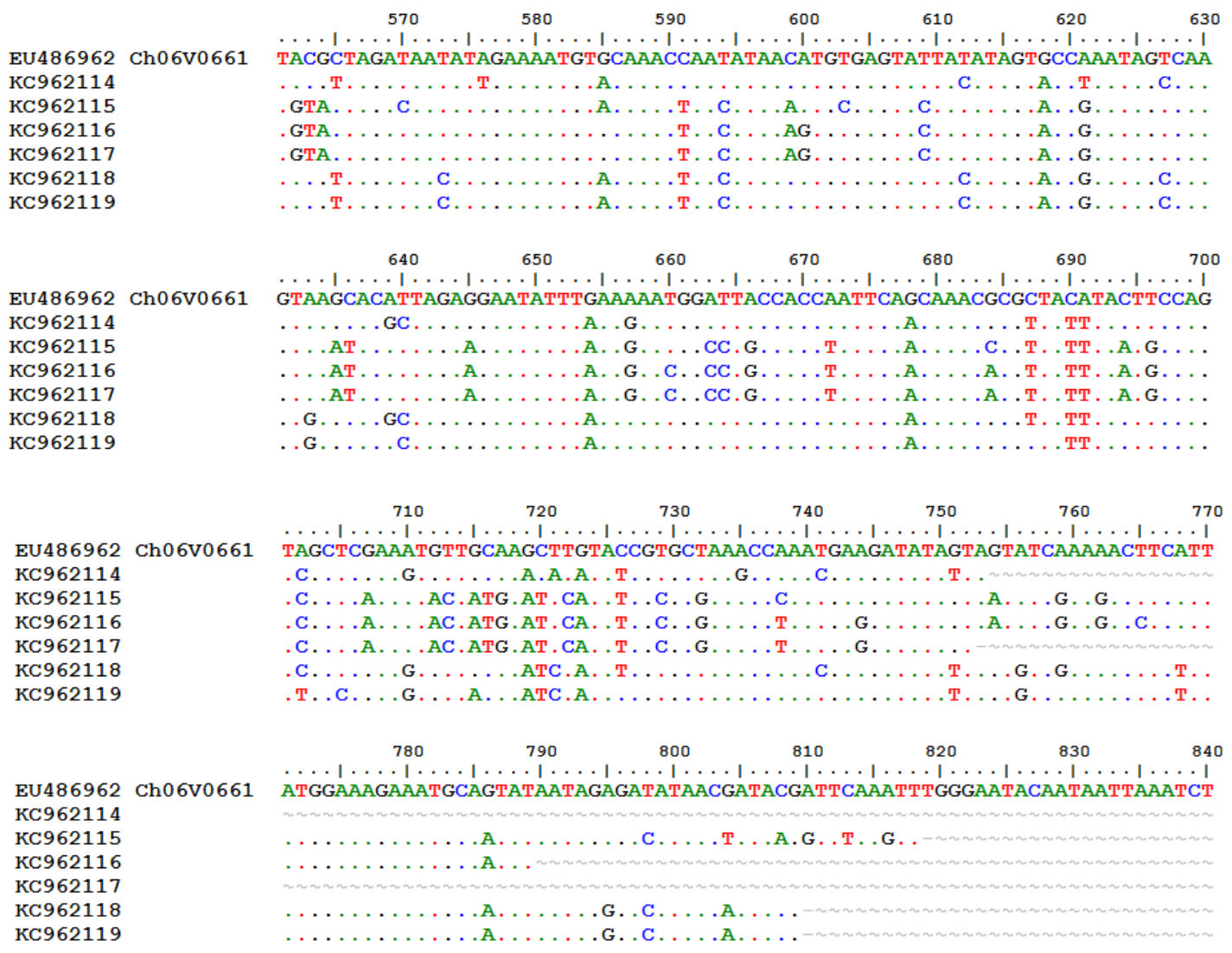

Fonte: Beserra (2013) 
Na figura 8 encontra-se representado o alinhamento das sequências traduzidas para aminoácidos do gene codificador da VP4 de rotavírus do grupo A referente às amostras geradas no presente estudo, identificadas como KC962114 a KC962121, tomando-se como referência a amostra Ch-06V0661 (número de acesso EU486962).

Figura 8 - Alinhamento das sequências traduzidas para aminoácidos do gene codificador da VP4 de rotavírus do grupo A em aves geradas no presente estudo. As setas em preto indicam dois sítios de clivagem proteolítica - São Paulo - 2013

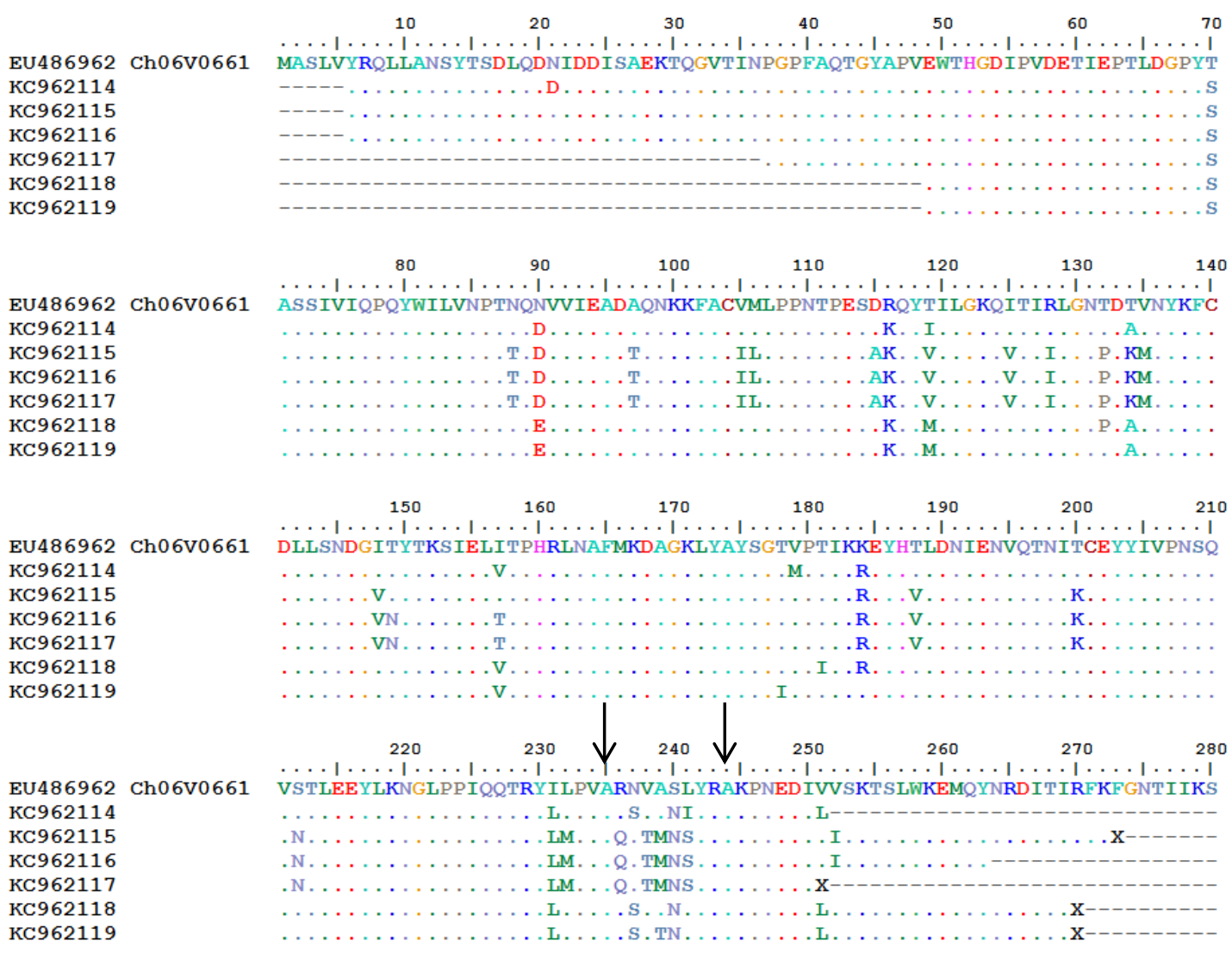

Fonte: Beserra (2013) 
O alinhamento das sequências de nucleotídeos contemplando tanto as amostras geradas neste estudo com as demais do Genbank representativas dos genotipos G19 e P[31] de VP7 e VP4, respectivamente, visando a elaboração da matriz de identidade e da inferência filogenética está apresentado no apêndice B e foi feito mediante a definição de uma área consensual de 683 nt de comprimento para VP7 e 603 nt para VP4. A região corresponde aos resíduos de nucleotídeos 113 a 796 do gene codificador da VP7 e de 145 a 752 da VP4.

No que se refere à VP6 de rotavírus do grupo D, encontra-se representado na figura 9 o alinhamento de nucleotídeos do gene codificador da VP6 de rotavírus do grupo D referente às amostras geradas no presente estudo, identificadas como KC689306 a KC689306, com as demais sequências de rotavírus do grupo D em aves recuperadas do GenBank.

Figura 9 - Alinhamento do fragmento parcial do gene codificador da VP6 de rotavírus do grupo D em aves gerados no presente estudo - São Paulo - 2013

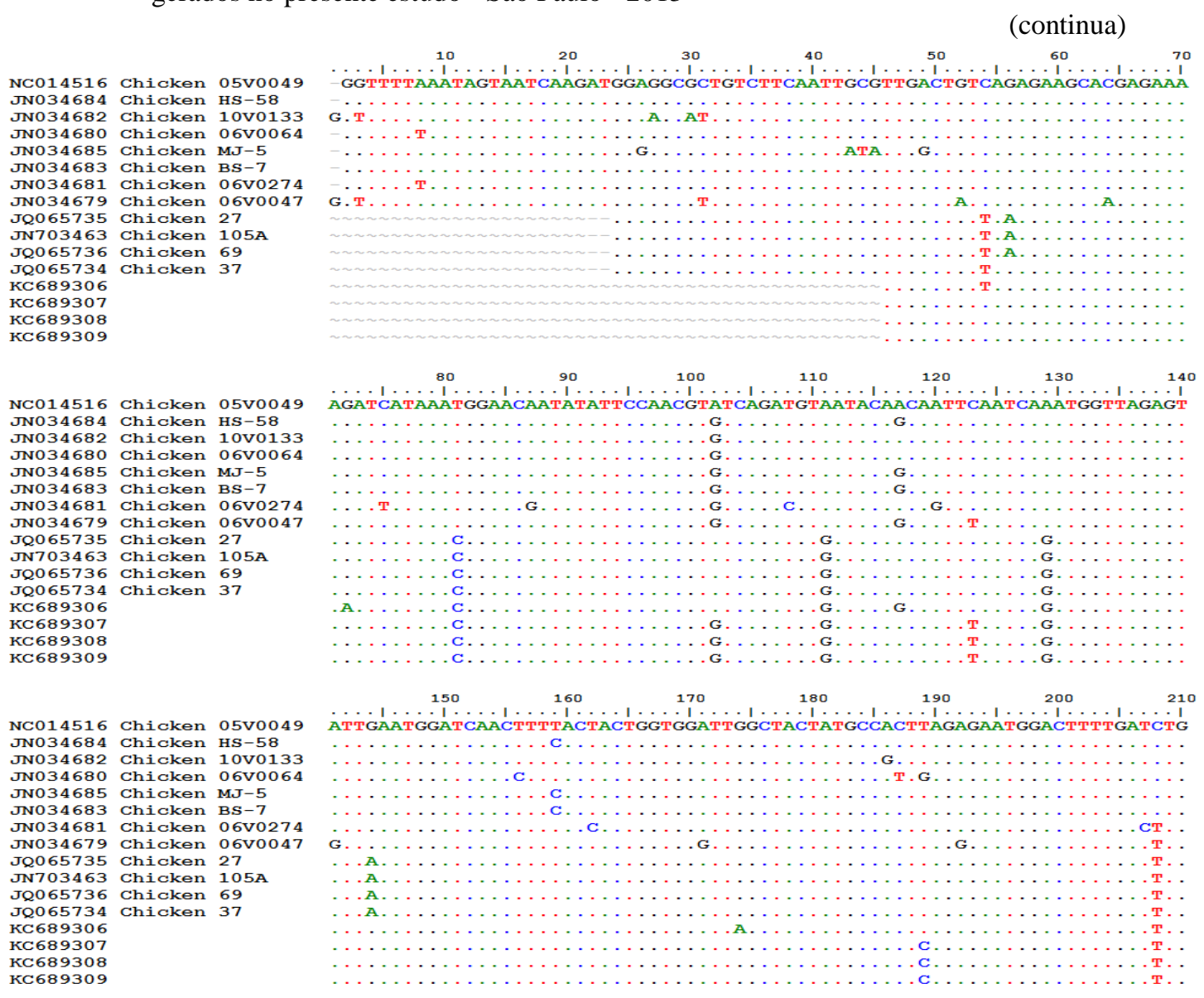

Fonte: Beserra (2013) 
Figura 9 - Alinhamento do fragmento parcial do gene codificador da VP6 de rotavírus do grupo D em aves gerados no presente estudo - São Paulo - 2013

(continuação)

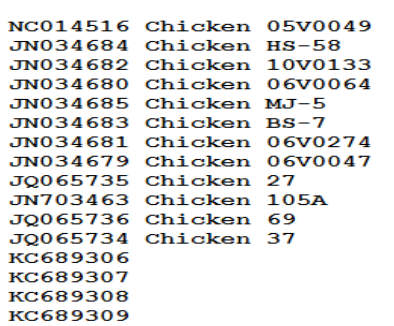

NC014516 Chicken 05voo49 JN034684 Chicken HS-58 JN034680 Chicken o6voo64

JN034685 Chicken MJ-5
JNo34683 Chicken BS-7

JNO34681 Chicken 06V0274 No 345735 chicken JN703463 Chicken $105 \mathrm{~A}$ JQ065734 Chicken 37

KC689306

(c68

KC689309

NC014516 Chicken o5voo49 JNO34684 Chicken HS-58 JN034680 Chicken o6voo64 JN034685 Chicken MJ-5

JN034683 Chicken BS-7

JN034681 Chicken O6V0274

J

JN703463 Chicken 105 A

JQ065736 Chicken 69
JQ065734 Chicken 37

KC689306

c6689307

KC689308

NC014516 Chicken o5voo49 JN034684 Chicken HS-58 JNo34682 Chiaken lovo133 JN034680 Chicken o6voo JNO34685 Chicken MJ-5 JN34683 Chicken BS-7 JN034679 Chicken O6V0047 JQ065735 Chicken 27
JN703463 Chiaken 105A JN703463 Chicken 105 A JQ065736 Chicken 69

KC689306

KC689307

KC689308
KC689309

NC014516 Chicken o5voo49 JNO34684 Chicken HS-58 JNO34682 Chicken 10V0133 JN034685 Chicken MJ-5

JN034683 Chicken BS-7

JN034681 Chicken 06V0274

JQ065735 Chicken 27

JQ065736 Chicken 69
JQ065734 Chicken 37

KC689306

KC689308

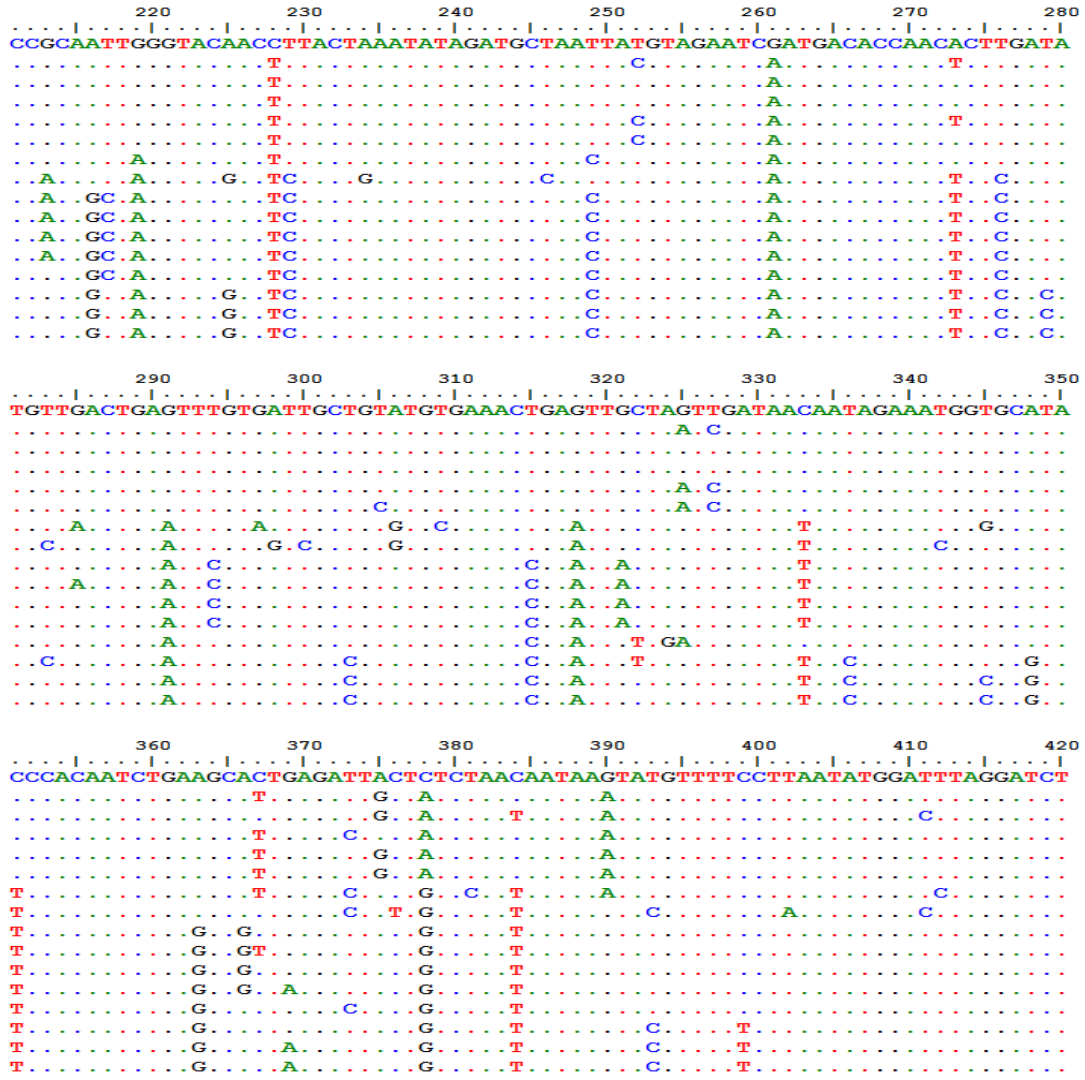

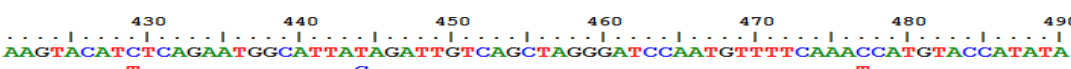

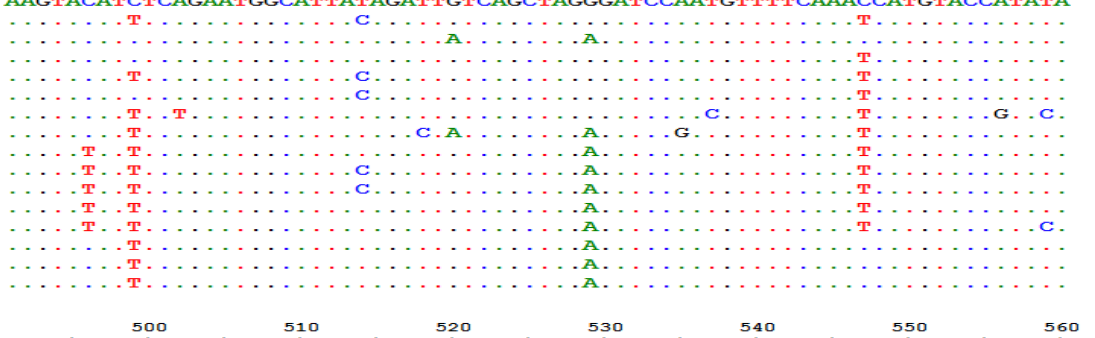

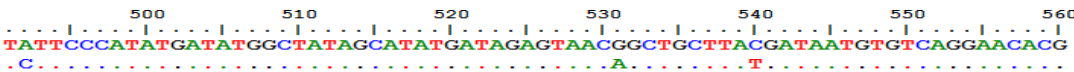

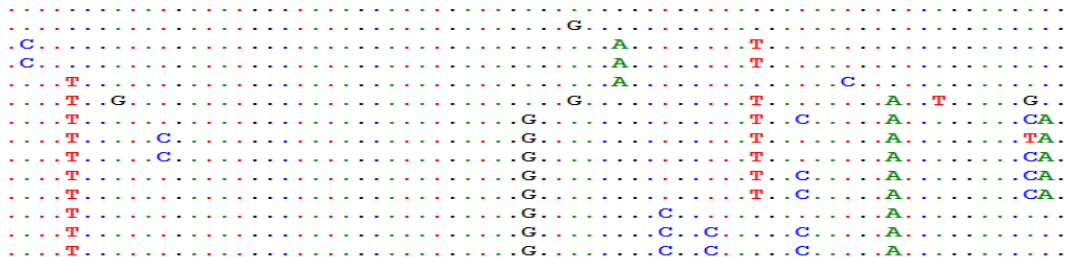


Figura 9 - Alinhamento do fragmento parcial do gene codificador da VP6 de rotavírus do grupo D em aves gerados no presente estudo - São Paulo - 2013

(conclusão)
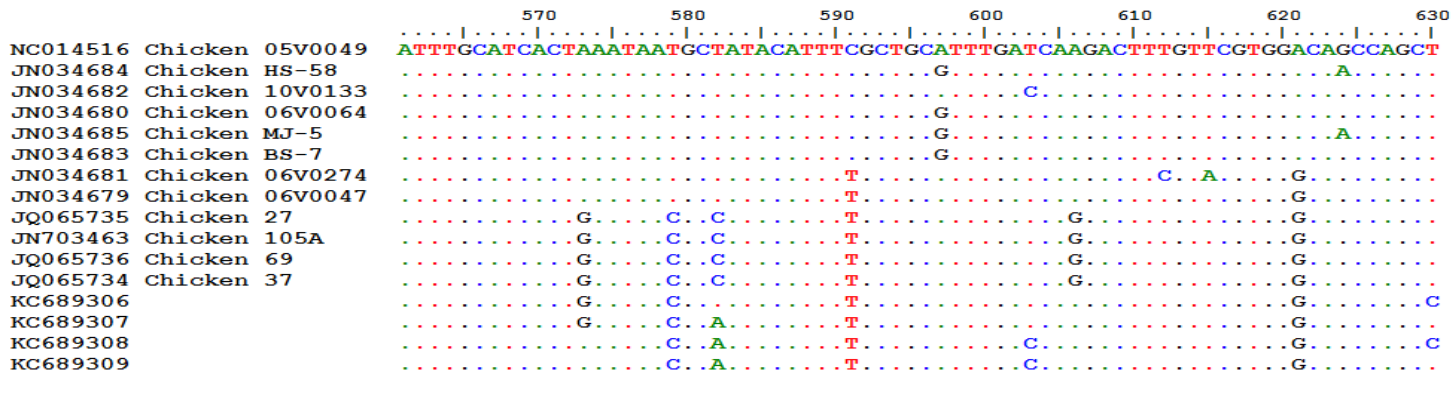

NC014516 Chicken 05voo49

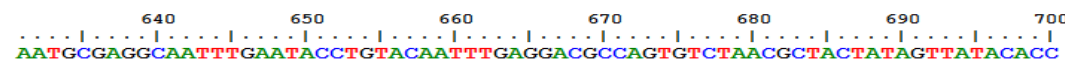
(1) -58 JN034682 Chicken 10V0133 JN034680 Chicken 06V0064 JN034685 Chicken MJ-5

$\begin{array}{lll}\text { JN034683 Chicken } & \text { BS-7 } \\ \text { JN034681 Chicken } & \text { 06V0274 }\end{array}$ NN034681 Chicken 06V0274 Jicken 06004 N75763 Chicken 27 A N703463 Chicken 105A JQ065736 Chicken 69 кC689306 KC689307 KC689308

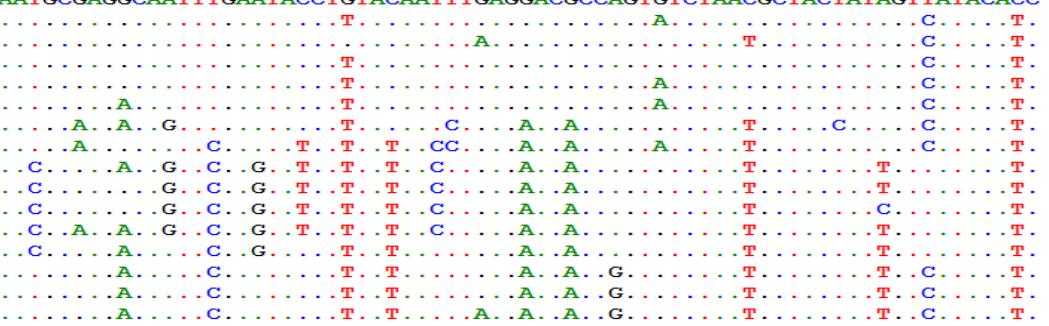

NC014516 Chicken 05voo49 JN034684 Chicken HS-58 No34682 Chicken 10V0133 N034683 Chicken BS-7

JN034681 Chicken 06V027 JN034679 Chicken 06v0047 JQ065735 Chicken 27 JN703463 Chicken 105A JQ065736 Chicken 69 JQ065734 Chicken 37 KC689306

KC689308

KC689308

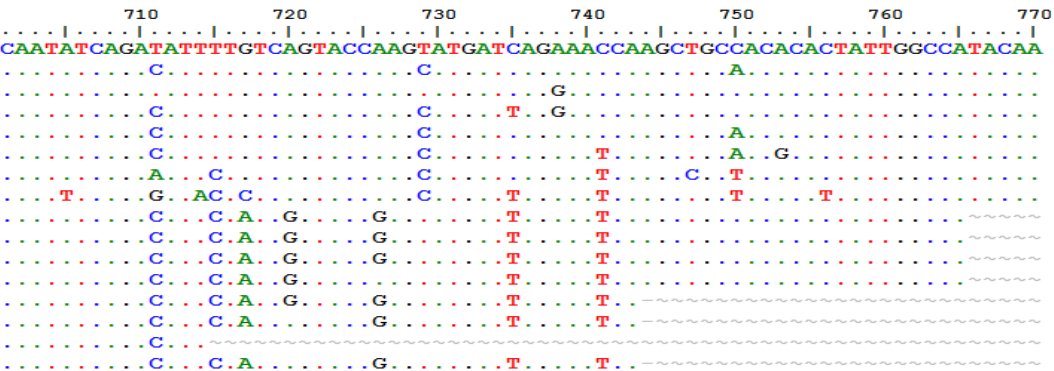

Fonte: Beserra (2013)

$\mathrm{Na}$ figura 10 encontra-se representado o alinhamento das sequências traduzidas para aminoácidos do gene codificador da VP6 de rotavírus do grupo D referente às amostras geradas no presente estudo, identificadas como KC689306 a KC689306, com as demais sequências de rotavírus do grupo $\mathrm{D}$ em aves recuperadas do GenBank. 
Figura 10 - Alinhamento da sequência traduzida para aminoácidos do gene codificador da VP6 de rotavírus do grupo D em aves gerados no presente estudo. As setas em preto indicam os resíduos de aminoácidos hidrofóbicos - São Paulo - 2013

NC014516 Chicken 05V0049
JN034684 Chicken HS-58
JN034682 Chicken 10V0133
JN034680 Chicken 06V0064
JN034685 Chicken MJ-5
JN034683 Chicken BS-7
JN034681 Chicken 06V0274
JN034679 Chicken 06V0047
JQ065735 Chicken 27
JN703463 Chicken 105A
JQ065736 Chicken 69
JQ065734 Chicken 37
KC689306
KC689307
KC689308
KC689309

KC689309

NC014516 Chicken 05V0049 JN034684 Chicken HS-58

JN034682 Chicken 10V0133

JN034680 Chicken 06V0064

JN034685 Chicken MJ-5

JN034683 Chicken BS-7

JN034681 Chicken 06V0274

JN034679 Chicken 06V0047

JQ065735 Chicken 27

JN703463 Chicken 105A

JQ065736 Chicken 69

JQ065734 Chicken 37

KC689306

KC689307

KC689308

KC689309

NC014516 Chicken 05V0049 JN034684 Chicken HS-58

JN034684 Chicken HS-58

JN034680 Chicken 06V0064

JN034685 Chicken MJ-5

JN034683 Chicken BS-7

JN034681 Chicken 06V0274

JN034679 Chicken 06V0047

JQ065735 Chicken 27

JN703463 Chicken 105A

JQ065736 Chicken 69

JQ065734 Chicken 37

KC689306

KC689307

KC689308

KC689309

NC014516 Chicken 05V0049 JN034684 Chicken HS-58

JN034684 Chicken HS-58
JN034682 Chicken 10V0133

JN034682 Chicken 10V0133
JN034680 Chicken 06V0064

JN034685 Chicken MJ-5

JN034683 Chicken BS-7

JN034681 Chicken 06V0274

JN034679 Chicken 06V0047

JQ065735 Chicken 27

JN703463 Chicken 105A

JQ065736 Chicken 69

JQ065734 Chicken 37

KC689306

KC689307

KC689308

KC689309

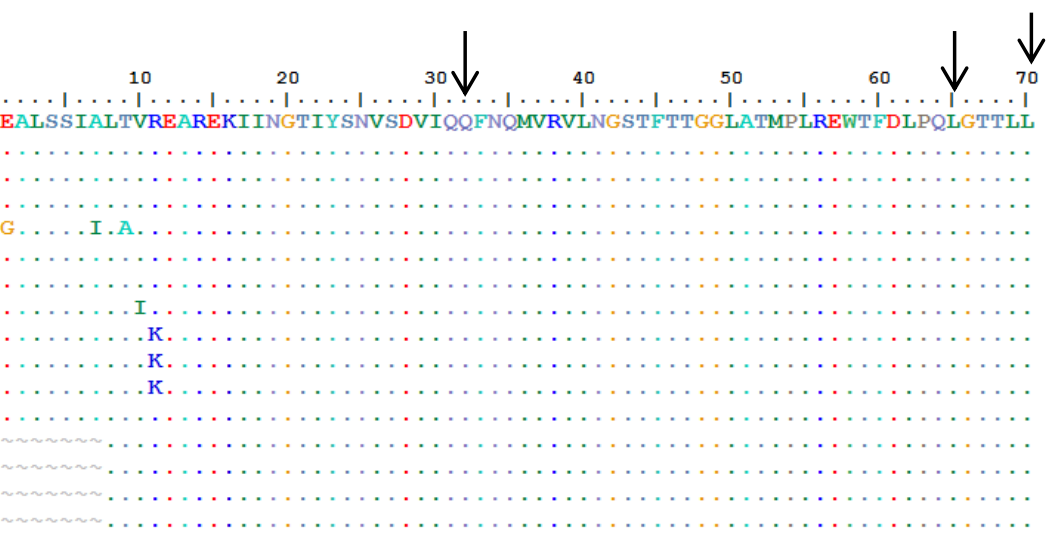

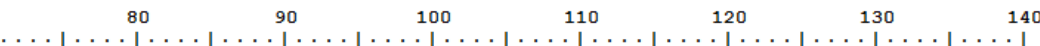

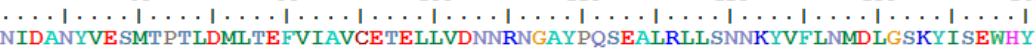

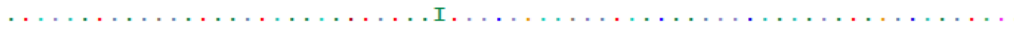
.

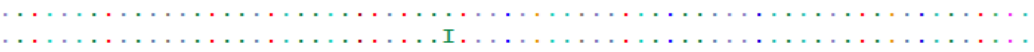

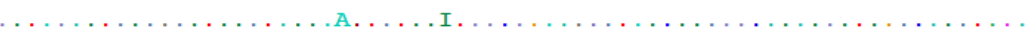

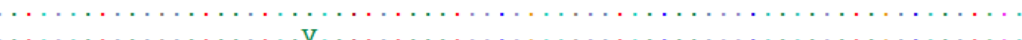

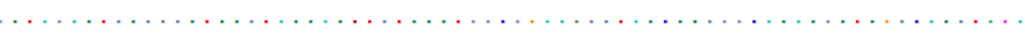

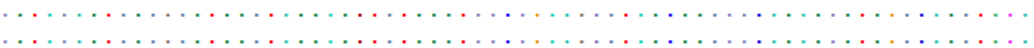

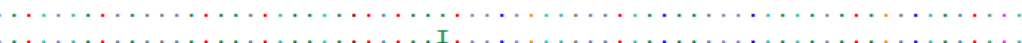

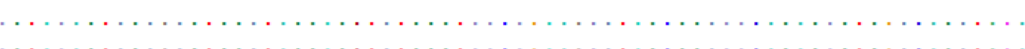

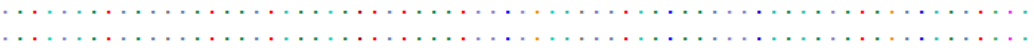

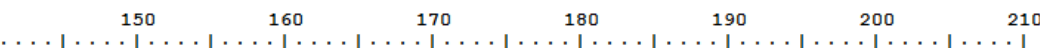

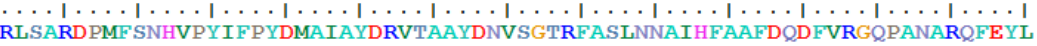

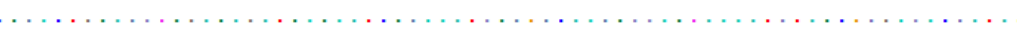

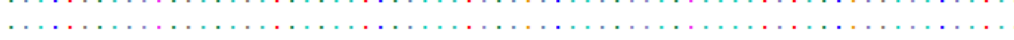

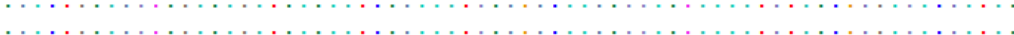

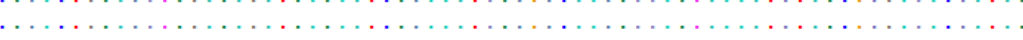

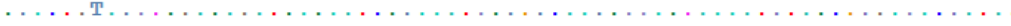

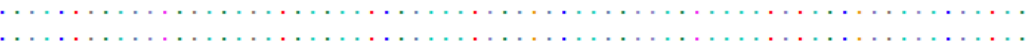
.

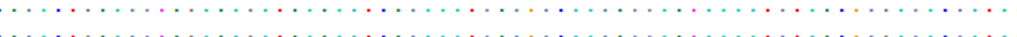

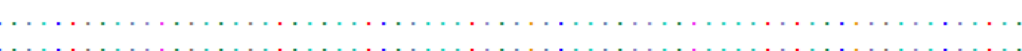
220
230
YNLRTPVSNATIVIHPISDILSVPSMIRN RLRTPVSNATIVIHPISDILSVPSMIRN

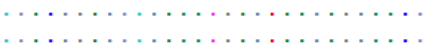

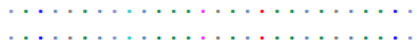
. $\ldots \ldots \ldots \ldots \ldots \ldots \ldots \ldots$

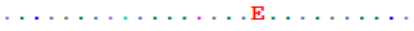
… $\ldots \ldots \ldots \ldots \ldots \ldots$

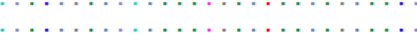
. $\ldots \ldots \ldots \ldots \ldots \ldots \ldots$ ... 
O alinhamento das sequências de nucleotídeos contemplando tanto as amostras de rotavírus do grupo D geradas neste estudo com as demais do Genbank também de rotavírus do grupo D, visando a elaboração da matriz de identidade e da inferência filogenética está apresentado no apêndice B e foi feito mediante a definição de uma área consensual de $664 \mathrm{nt}$ de comprimento para VP6. A região corresponde aos resíduos de nucleotídeos 46 a 714 do gene codificador da VP6

\subsection{Matrizes de identidade}

Os valores de identidade nucleotídica e de aminoácidos da região consensual das sequências de rotavírus do grupo A geradas neste estudo (USPARV05 e USPARV06) e frente às demais representativas do genotipo G19 de VP7 depositadas no Genbank, estão apresentadas no quadro 8 e apêndice D.

Quadro 8 - Valores de identidade nucleotídica e de aminoácidos da região consensual das sequências de rotavírus geradas neste estudo (USPARV05 e USPARV06), bem como frente às demais representativas do genotipo G19 de VP7 de rotavírus do grupo A depositadas no Genbank - São Paulo - 2013

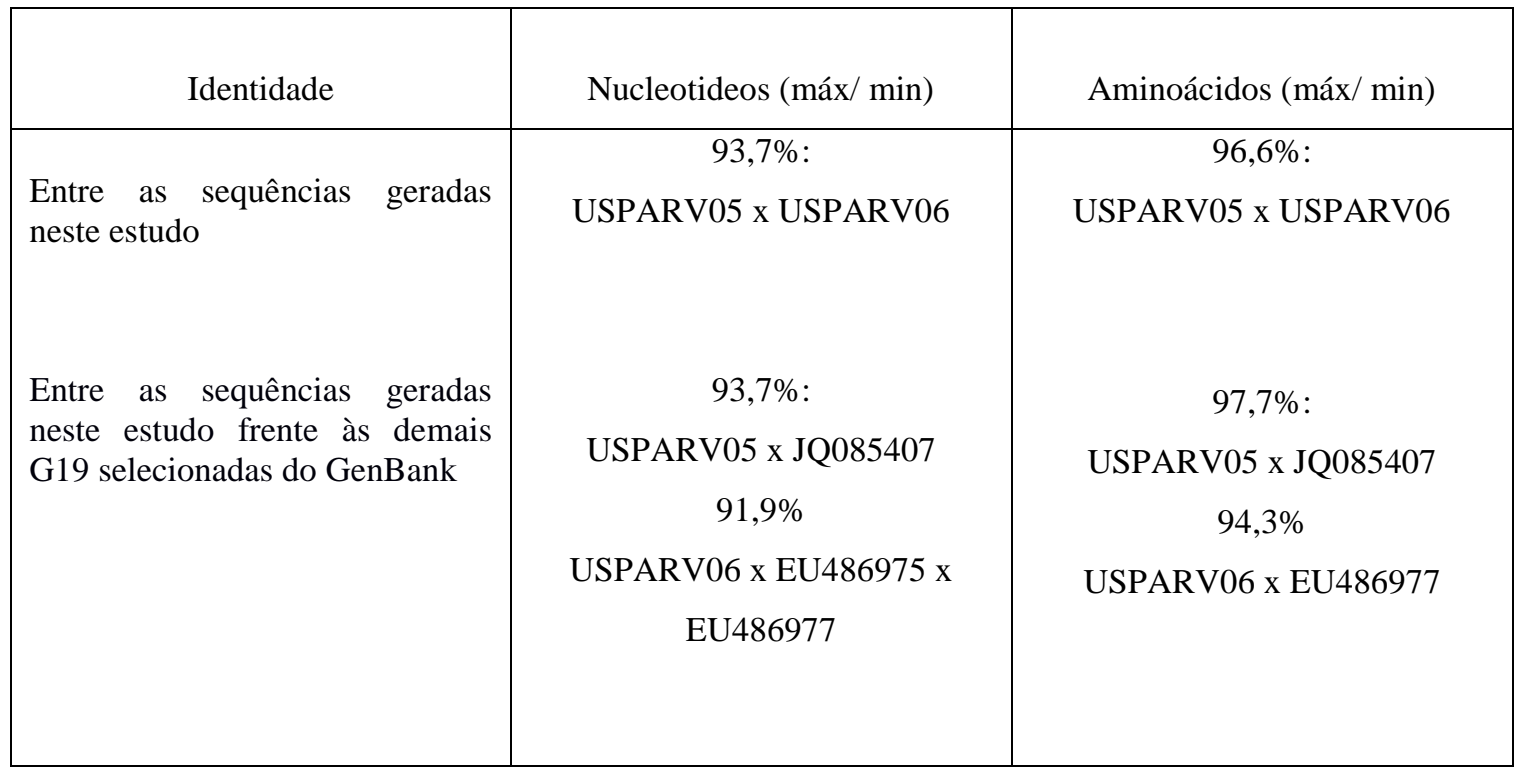


Os valores de identidade nucleotídica e de aminoácidos da região consensual das sequências de rotavírus do grupo A geradas neste estudo (USPARV01 a USPARV06) e frente às demais representativas do genotipo P31 de VP4 de rotavírus do grupo A depositadas no Genbank, estão apresentadas no quadro 9 e apêndice E.

As amostras USPARV07 e USPARV08, por possuírem uma região consensual diferente das demais geradas no estudo, tiveram seus valores de identidade nucleotídica e de aminoácidos definidos separadamente e estão apresentados no quadro 10.

Quadro 9 - Valores de identidade nucleotídica e de aminoácidos da região consensual das sequências de rotavírus geradas neste estudo (USPARV01 a USPARV06), bem como frente às demais representativas do genotipo P31 de VP4 de rotavírus do grupo A depositadas no Genbank - São Paulo - 2013

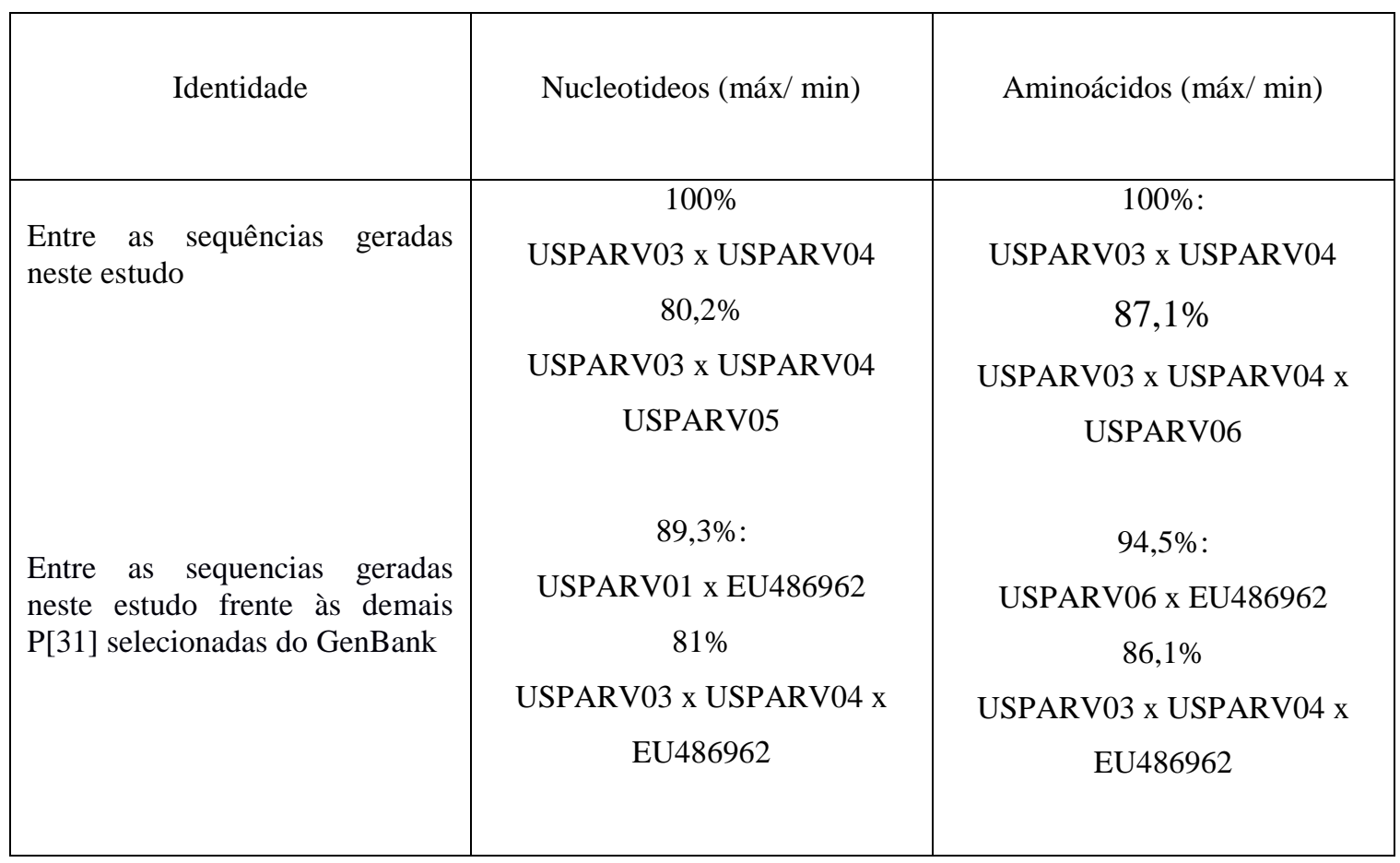


Quadro 10 - Valores de identidade nucleotídica e de aminoácidos da região consensual das sequências de rotavírus geradas neste estudo (USPARV07 e USPARV08), bem como frente às demais representativas do genotipo P[31] de VP4 de rotavírus do grupo A depositadas no Genbank - São Paulo - 2013

\begin{tabular}{|l|c|c|}
\hline \multicolumn{1}{|c|}{ Identidade } & Nucleotideos & Aminoácidos \\
\hline $\begin{array}{l}\text { Entre a sequência USPARV07 } \\
\text { gerada neste estudo frente P[31] } \\
\text { selecionada do GenBank }\end{array}$ & $86,5 \%$ & $93,7 \%$ \\
$\begin{array}{l}\text { Entre a sequência USPARV08 } \\
\text { gerada neste estudo frente P[31] } \\
\text { selecionada do GenBank }\end{array}$ & $82 \%$ & $86 \%$ \\
\hline
\end{tabular}

Fonte: Beserra (2013)

Os valores de identidade nucleotídica e de aminoácidos da região consensual das sequências de rotavírus do grupo D geradas neste estudo (AVRVBR1 a AVRVBR4) e frente às demais representativas, também do grupo $\mathrm{D}$, depositadas no Genbank, estão apresentadas no quadro 11 e apêndice $F$. 
Quadro 11 - Valores de identidade nucleotídica e de aminoácidos da região consensual das sequências de rotavírus do grupo D geradas neste estudo (AVRVBR1 a AVRVBR4), bem como frente às demais representativas de rotavírus do grupo D em aves depositadas no Genbank - São Paulo 2013

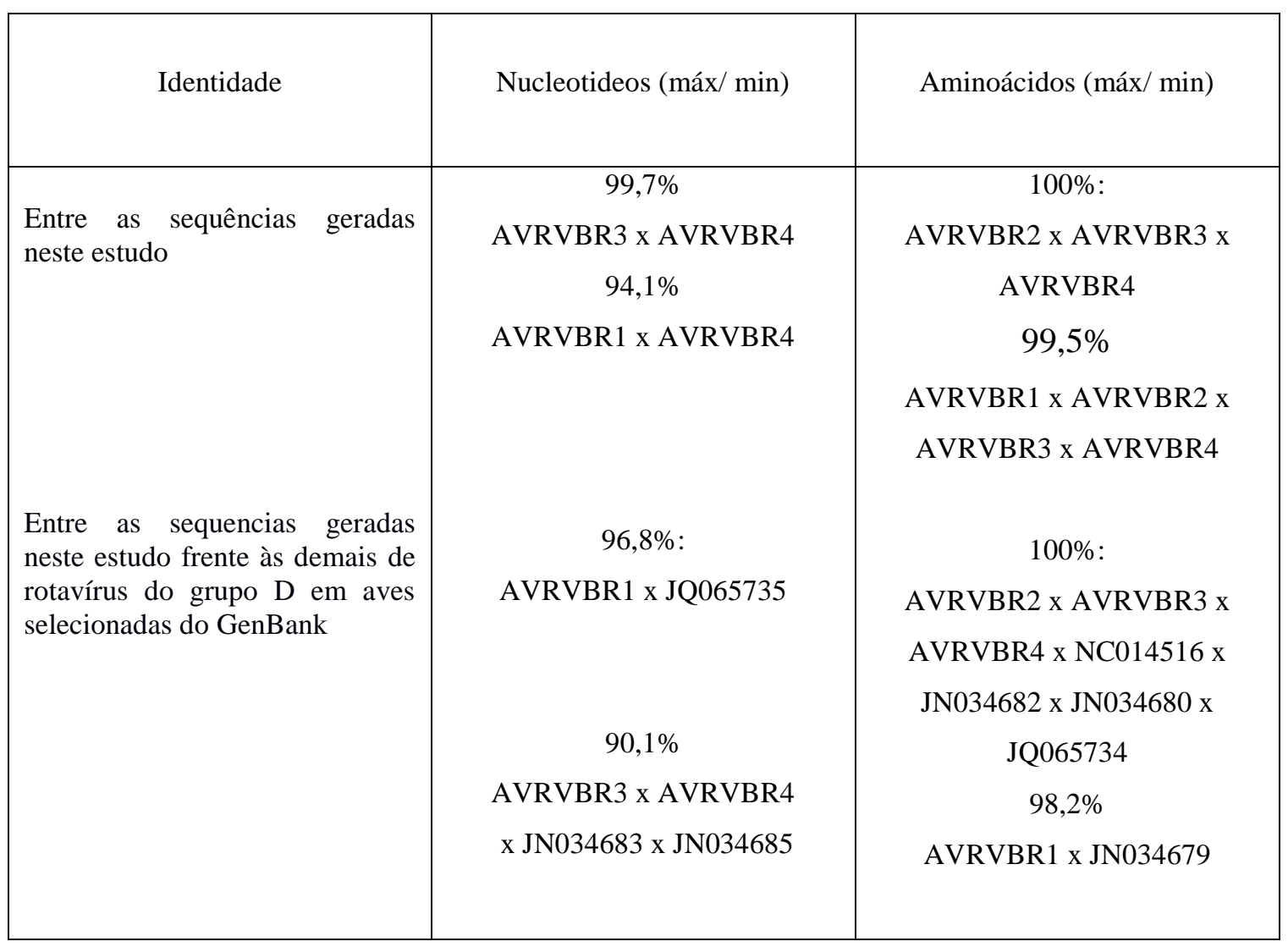

Fonte: Beserra (2013) 


\section{DISCUSSÃO}

Os rotavírus são uma das mais importantes etiologias associadas à enterites resultando em doença clínica principalmente em aves jovens (RIOS et al., 2012). Sua ocorrência está descrita, entre outras, em galinhas, faisões, perus, avestruzes (MACLACHAN; DUBOVI, 2011).

Descrevemos aqui a ocorrência de rotavírus do grupo A em aves provenientes dos estados do Paraná, São Paulo, Rio Grande do Sul, Santa Catarina e Goiás, com frequência de 38,73\% através da adoção em paralelo dos testes de ELISA, PAGE e RT-PCR NSP5 (itens 5.1; 5.2; 5.3.1, respectivamente) sendo 55,81\% (24/43) oriundos de criações de frango de corte, $18,6 \%$ (8/43) de matrizes, 13,95\% de aves de postura, 2,32\% (1/43) de avozeiros e em 9,3\% (4/43) das amostras não foi possível identificar quanto ao estado e tipo de criação de origem.

Além disso, foi definida a frequência de ocorrência de 6,3\% (7/111) de rotavírus do grupo D a partir do mesmo universo amostral por RT-PCR e confirmado por sequenciamento nucleotídico parcial (itens 5.3.6; 5.4.4), sendo que 85,71\% (6/7) são provenientes de criações de frango de corte e 14,28\% (1/7) de matrizeiro, localizados nos estados de Goiás, Paraná e São Paulo.

A ocorrência de rotavírus aviários no Brasil tem sido relatada desde 1989 (ALFIERI et al., 1989b), em frangos de corte através da técnica de PAGE.

Tamehiro et al. (2003), também mediante emprego da PAGE, demonstraram ocorrência de 8,5\% (32/378) de rotavírus em amostras de fezes de aves, com idade entre a primeira e sétima semanas de vida, provenientes de granjas avícolas localizadas no Estado do Paraná, Brasil. Observaram maior ocorrência em aves com até um mês de idade apresentando sinais clínicos de enterite. Ao se considerarem apenas as amostras de fezes diarreicas, o rotavírus foi detectado em $37,8 \%(14 / 37)$ do total analisado.

Villarreal et al. (2006) ao estudarem matrizes e frangos de corte através da técnica de PAGE descreveram a ocorrência de 45,3\% (58/128 amostras) de amostras positivas a partir de conteúdo intestinal. 
Rios et al. (2012) descreveram a ocorrência de 9,25\% (5/54) de rotavírus do grupo A a partir de amostras fecais de frango de corte, com sinais clínicos de enterite, em três municípios de Minas Gerais também pela técnica de PAGE.

Além da avicultura, os rotavírus do grupo A foram detectados em conteúdo intestinal de perus através de RT-PCR onde foi definido o genotipo tipicamente bovino, G6P[1], (ASANO et al., 2011) e em seis amostras fecais de avestruz através de PAGE e RT-PCR definindo os genotipos $\mathrm{P}[1]$, e as associações $\mathrm{P}[1] \mathrm{P}[7]$, G6P[1] e G10P[1] encontradas em suínos e bovinos, indicando ocorrência de transmissão interespécie ou "reassortment" (SILVA et al., 2012).

No que diz respeito aos rotavírus do grupo $\mathrm{D}$, existem poucos relatos na literatura. Rotaviroses deste grupo foram primeiramente descritos em fezes de frango de corte no Reino Unido e na Alemanha (MCNULTY et al., 1984; SAIF et al., 1985; PEDLEY et al., 1986).

Alfieri et al. (1989a) analisaram 22 amostras, inicialmente positivas pela reação de PAGE, por duas técnicas de ELISA grupo A (mono e policlonal). Todas as 22 amostras foram negativas quanto a presença do rotavírus indicando que as amostras não se relacionavam ao sorogrupo A de rotavírus de mamíferos.

Otto et al. (2012) descreveram a ocorrência 39,2\% de amostras positivas para rotavírus do grupo D através de PCR convencional e de 65,9\% através de PCR em tempo real a partir de em amostras fecais de frangos e perus em países da Europa e em Bangladesh.

No Brasil, Bezerra et al. (2012) detectaram nove (9/30) amostras positivas através da PAGE e 16 (16/30) por RT-PCR, definindo 4 sequências que apresentaram elevada identidade nucleotídica com rotavírus do grupo D, com base no gene codificador da VP6.

Portanto, os dados de frequência de ocorrência de rotavírus do presente estudo de certa forma assemelham-se àqueles descritos pelos autores aqui citados. Apesar das limitações amostrais deste estudo, estes resultados permitem afirmar uma ampla disseminação dos rotavírus em aves, visto que em 5 estados brasileiros foi diagnosticada a circulação do agente. Se considerada a modalidade de criação, uma menor frequência de ocorrência em avozeiros pode ser justificada por melhores condições de manejo, sobretudo no que diz respeito aos aspectos de biossegurança adotados. 
Cabe ressaltar que nenhuma das amostras positivas para rotavírus do grupo D foi também positiva pela reação de RT-PCR (NSP5), confirmando a especificidade das mesmas, já que esta última é direcionada para a detecção de rotavírus do grupo A.

De acordo com a reação de ELISA, obteve-se 5,4\% (6/111) de frequência de amostras positivas quanto a presença de rotavírus do grupo A (item 5.1). Neste caso pode-se levar em consideração a possibilidade de ocorrência de resultado falso-negativo, se comparados à RTPCR para o gene codificador da NSP5 de rotavírus A (item 5.3.1; tabela 4), devido a diferenças antigênicas na VP6 que é o principal antígeno identificado nos sistemas de ELISA grupo A específicos (ALFIERI et al., 1989b), excluindo, portanto, as amostras positivas para rotavírus do grupo D, detectadas no presente estudo pela reação de RT-PCR para o gene VP6.

Outra explicação para a baixa concordância entre as provas de ELISA se comparadas com PAGE (item 5.2; Tabela 1) e RT-PCR (item 5.3.2; Tabela 3), seria a perda da estrutura das proteínas virais, já que esta técnica independe da viabilidade da partícula, mas sim da sua integridade, especialmente a VP6 (ESTES; KAPIKIAN, 2007).

No que se refere a PAGE obteve-se uma ocorrência de $9 \%$ (10/111) de rotavírus do grupo A (item 5.2). Apesar de baixa, a frequência aqui encontrada, está de acordo com outros estudos citados anteriormente. No entanto pode-se atribuir a baixa concordância, no que se refere à RT-PCR NSP5 (item 5.3.1; tabela 4), à sensibilidade analítica da PAGE, pois esta depende de elevada carga viral para visualização das bandas, o que poderia levar a resultados "falsos-negativos", sobretudo onde há pouca eliminação viral (HERRING et al., 1982; WINIARCZYK; GRADZKI 2002).

Com o intuito de aumentar a sensibilidade diagnóstica das amostras, realizou-se adicionalmente a técnica de RT-PCR em paralelo tendo como alvo o gene codificador da proteína não estrutural 5 (NSP5) dos rotavírus (SALEM et al., 2010) que apresenta elevada conservação entre os isolados das diversas espécies animais. A partir desta, obteve-se 35,13\% (39/111) de amostras positivas quanto à presença de rotavírus do grupo $\mathrm{A}$. O sequenciamento nucleotídico de 3 produtos de RT-PCR (NSP5), que aliás eram também positivos também por PAGE e ELISA, confirmaram os achados de rotavírus, com base na elevada identidade (item 5.4.1).

Das 39 amostras positivas por NSP5 (item 5.3.1), foi possível definir o genotipo G5, G8 e G11 através de RT-PCR multiplex (item 4.6.1) em 20,31\% (8/39) (item 5.3.3; Tabela 4). 
Tais genotipos não estão relacionados com aqueles encontrados tipicamente em aves tais como o G7, G17 e G22 em perus, G18 em pombo, G19 em galinhas, e G23 em faisão (MATTHIJNSSENS et al., 2011), mas relacionados a surtos em bovinos (G8, além de G6 e G10) e suínos (G5 e G11), evidenciando a possibilidade de transmissão interespécie (PARK et al., 2006). Como as fichas de identificação das amostras de campo deste estudo não continham informações sobre o nível de biossegurança e presença de outras espécies animais que eventualmente poderiam ter tido contato com estas aves, fica restrita a hipótese de transmissão, muito embora, por se tratarem de criações comerciais, supõe-se minimamente algum tipo de controle.

Algumas hipóteses podem ser levantadas no sentido de se compreender a não genotipagem de todas as amostras positivas pela reação de RT- PCR NSP5 (item 5.3.1) citadas anteriormente. Uma delas diz respeito à integridade do RNA viral, submetido a condições de variação de temperatura, elevada umidade e presença de inibidores inespecíficos, como é o caso das fezes, que poderiam degradar o genoma viral (WILSON, 1997) e com isso gerar resultados negativos. Entretanto, podemos refutar parcialmente esta hipótese, visto que a prova de RT-PCR visando a NSP5 também depende da integridade do material genético viral, que por sua vez resultou em 39 pools positivos.

Aliás, a não genotipagem é um fato relativamente comum em estudos de caracterização viral, tal como descrito por Silva et al. (2012) que obteve 50\% de genotipagem da VP7 em 6 amostras fecais de avestruz oriundas de isolamento viral, sendo que as mesmas foram positivas por PAGE, seguida de passagens em célula MA-104 e novamente visualizadas as bandas por PAGE confirmando o isolamento.

Ainda, Winiarczyk e Gradzki (2002) genotiparam 96,8\% de G e 87,1\% de P das amostras de rotavírus dos Estados Unidos, mas na Polônia, obtiveram apenas 54,5\% de G e 38,6\% de P. Parra et al. (2008), ao genotiparem 30 amostras argentinas, tiveram sucesso em identificar o genótipo de apenas 8 delas $(26,67 \%)$.

Tal fato pode ser explicado caso o rotavírus presente na amostra pertença a um outro diferente daqueles contemplados pelos primers utilizados nas reações (WINIARCZYK; GRADZKI, 2002) ou mesmo mutações pontuais nos sítios de ligação dos primers (PARRA et al., 2008). Uma alternativa seria a de se sequenciar os produtos provenientes da primeira amplificação por PCR (item 4.6.2) do gene codificador da VP7, mas que, dada a baixa concentração de DNAc, 
entre outros motivos, não foi possível obtê-los, restando-nos o desenho de novos primers (item 4.6.2.1)

No que diz respeito à caracterização genotípica do gene codificador da VP4 em aves não foi possível obter genotipos utilizando os "primers" descritos por Gouvea et al. (1994b), obtendose apenas o produto da primeira amplificação em 13 amostras (33,33\% ou 13/39) (item 5.3.5). Desta forma a definição dos genotipos em 8 amostras foi feita através do sequenciamento destes produtos (item 5.4.3) e sua respectiva inferência filogenética (item 5.5.2), contando com representantes de todos os genotipos de rotavírus conhecidos.

À semelhança da VP7, explica-se a não genotipagem das amostras testadas neste estudo por não pertencem àqueles contemplados pelos "primers" utilizados (item 4.6.2), enquanto que a dificuldade para obtenção de sequências nucleotídicas consistem principalmente na pouca quantidade de DNA presente na reação de PCR, ou a perda de rendimento nas diferentes etapas da reação, entre elas a purificação dos produtos após a incorporação de terminadores.

De acordo com a árvore filogenética apresentada no item 5.5.2, observa-se que as amostras deste estudo agruparam-se no genotipo $\mathrm{P}$ [31], amparadas também pelo resultado da consulta à base Rota-C e pelos valores de identidade (Apêndice E). Este genotipo é comumente descrito em aves, assim como o $\mathrm{P}[17]$ em pombos, $\mathrm{P}[30$ ] em frangos, $\mathrm{P}$ [35] em perus (MATTHIJNSSENS et al., 2011) e mais recentemente descrito o genotipo P[37] em faisões. (TROJNAR et al., 2013). Para o nosso conhecimento, trata-se da primeira descrição do genotipo $\mathrm{P}[31]$ no Brasil.

Pode-se observar adicionalmente que as amostras de rotavírus de galinhas não se encontram em um cluster exclusivo de aves, no qual encontra-se a amostra 993/83 (número de acesso D16352), isolada de bezerros com diarreia na Alemanha, que apresenta elevada similaridade com a amostra PO-13 (número de acesso AB0099632) isolada de pombo no Japão (BRUSSOW et al., 1992), o que sugere também transmissão interespécies.

Além disso, a amostra10V0112H5 (número de acesso JX204814), identificada em faisão, pertencente ao genotipo recentemente descrito $\mathrm{P}$ [37], não encontra-se no cluster predominantemente de aves. Essa amostra possui maior relação com rotavírus do grupo A de humanos, suínos e cães, o que indica tratar-se de um "reassotment" entre aves e mamíferos ou que carrega um gene VP4 aviário incomum, ampliando assim o potencial de variabilidade genética e antigênica entre rotavírus do grupo A (TROJNAR et al., 2013). 
Vale ressaltar que a topologia da árvore (item 5.5.2; Figura 3) manteve segregados os diferentes genotipos, amparados inclusive por altos valores de "bootstrap".

Com relação ao sequenciamento (item 5.4.2) de outras duas amostras pela reação de RTPCR com os primers desenhados no presente estudo visando o gene codificador da VP7 (item 4.6.2.1) - USPARV05 (número de acesso KC962122) e USPARV06 (número de acesso KC962123) tiveram identidade nucleotídica de 93,7\%, ressaltando que tratam-se de amostras provenientes de criações de frango de corte do estado do Paraná, porém colhidas de uma mesma propriedade o que sugere a circulação de diferentes amostras na região ao longo do tempo (Tabela 4).

A respectiva inferência filogenética (item 5.5.1; Figura 2) guardou correspondências com a matriz de identidade e os genotipos anteriormente descritos (MATTHIJNSSENS et al., 2011). Essas amostras (USPARV05 e USPARV06) mantiveram-se em um cluster isolado G19, cujo nó contempla predominantemente representantes de aves, com maior proximidade à amostra AvRV2, confirmado através do uso da base de dados de classificação RotaC de rotavírus do grupo A (MAES et al., 2009).

Entre as sequências geradas neste estudo frente às demais G19 selecionadas do GenBank, mediante a visualização da matriz de identidade (item 5.7; Quadro 8), constatou-se que a amostra USPARV05 teve 93,7\% de semelhança em termos de nucleotídeos com a amostra aviária AvRV2 (número de acesso JQ085407) enquanto que a maior diferença observada $(8,1 \%)$, também em relação aos nucleotídeos, foi entre a amostra USPARV06 e as amostras 03V0358F3 (número de acesso EU486975) e 06V0661 (número de acesso EU486977), também de origem aviária.

Se considerarmos a identidade em termos de aminoácidos entre as amostras geradas no estudo, ela foi de 96,6\% (USPARV05 x USPARV06). Levando em consideração a identidade entre as amostras geradas e as demais do genotipo G19 selecionadas do GenBank, ela foi de 97,7\% entre a amostra USPARV05 e AvRV2 e a maior diferença (5,7\%) foi observada entre as amostras USPARV06 e 06V0661 (item 5.7; Quadro 8).

No que diz respeito às identidades entre as 8 sequencias parciais do gene codificador da VP4, as amostras geradas tiveram identidade nucleotídica variando de 100\% entre USPARV03 (número de acesso KC962116) e USPARV04 (número de acesso KC962117) a 81,2\% entra estas 
mesmas amostras e a USPARV05 (número de acesso KC962118) e USPARV06 (número de acesso KC962118) (item 5.7; Quadro 9).

Cabe ressaltar que as amostras USPARV03 e USPAARV04 são provenientes da mesma granja, porém de aves alojadas em diferentes galpões, considerando-se também que as aves não possuíam sinais clínicos de enterite no momento da coleta, muito embora tenha sido relatada a ocorrência nesta criação, sugerindo uma exposição viral comum.

A identidade nucleotídica entre a amostra USPARV01 (número de acesso KC962114) do presente estudo e a amostra recuperada do GenBank, pertencente ao genotipo P[31], Ch06V0661 (número de acesso EU486962) foi de 89,8\%; enquanto que a menor identidade observada $(82,1 \%$ ) foi entre a mesma amostra Ch06V0661 e USPARV03 (número de acesso KC962116) e USPARV04 (número de acesso KC962117) (item 5.7; Quadro 9).

Se levarmos em consideração a identidade em termos de aminoácidos entre as amostras aqui geradas, temos a variação de 100\% entre USPARV03 e USPARV04 a 88,1\% entre a amostra USPARV03 e USPARV04 e USPARV06. Já entre a amostra recuperada do GenBank Ch06V0661 variou de 95,7\%, entre a amostra USPARV06 (número de acesso KC962119), a 87,7\%, entre a mesma e as amostras USPARV03 (número de acesso KC962116) e USPARV04 (número de acesso KC962117) (item 5.7; Quadro 9).

Estes dados de identidade nucleotídica e de aminoácidos dos genes VP4 e VP7 convergem para a constatação de uma diversidade intra-genotípica entre os rotavírus circulantes, sendo este um mecanismo que poderia favorecer a transmissão interespécie, nesse sentido a comparação da patogenicidade e virulência causadas por substituições de aminoácidos é necessária para a compreensão mais ampla das infecções causadas por rotavírus (GREGORI et al., 2012).

Já para os rotavírus do grupo D, das sete amostras positivas pela PCR (das 111 testadas) visando o gene codificador da VP6, foi possível definir quatro sequências parciais (item 5.4.4). As amostras AVRVBR03 (número de acesso KC689308) e AVRVBR04 (número de acesso KC689309) tiveram identidade nucleotídica de 99,7\% (item 5.7; quadro 11), sendo estas provenientes da mesma granja e colhidas no mesmo momento.

Entre as sequências geradas neste estudo frente às demais selecionadas do GenBank pertencentes ao grupo $\mathrm{D}$, mediante a visualização da matriz de identidade, constatou-se que a amostra AVRVBR1 (número de acesso KC689306) teve 93,7\% de semelhança em termos de 
nucleotídeos com a amostra aviária 27 (número de acesso JQ065735) enquanto que a menor identidade observada $(90,1 \%)$ foi entre as amostras AVRVBR3 (número de acesso KC689308) e AVRVBR4 (número de acesso KC689309) e as amostras BS7 (número de acesso JQ034683) e MJ5 (número de acesso JQ034683), também de origem aviária (item 5.7; Quadro 11).

Porém, se considerarmos a identidade em termos de aminoácidos entre as amostras geradas no estudo, ela foi de 100\% (AVRVBR02 x AVRVBR03 x AVRVBR04).

Ao observar-se a análise filogenética de sequências genômicas completas de rotavírus, Ogden et al. (2012) identificaram dois grandes clados formados por rotavírus dos grupos A / C / D / F e rotavírus dos grupos B / G / H. Essa segregação está claramente definida na análise de cada um dos seis genes de proteínas estruturais, bem como também presente em dois dos cinco genes de proteínas não estruturais.

A árvore gerada (item 5.5.3; Figura 4) manteve esta mesma divisão de grupos em dois clados principais, suportados por valores elevados de bootstrap, apesar de ser um fragmento parcial do gene da VP6. Tomados em conjunto, o uso de um primer específico para rotavírus do grupo D (BEZERRA et al., 2012), a identidade de sequência de aminoácidos elevada (100\%) e a segregação das amostras no clado do grupo D, mostram que as amostras detectadas pertencem de fato ao grupo $\mathrm{D}$.

Finalmente, considerando que os rotavírus A e D encontram-se disseminados nas diferentes modalidades de criações comerciais de aves no Brasil, contando com diferentes genótipos em circulação, alguns deles atípicos para a espécie aviária, tal como demonstrado no presente estudo, torna-se necessário um maior entendimento deste agente, ampliando-se o escopo para os demais genes e se possível com a associação de achados clínicos e patológicos, de modo a se aprimorar a prevenção e controle desta doença. 


\section{CONCLUSÕES}

Podemos concluir que:

- Do total de amostras pesquisadas, obteve-se uma frequência de ocorrência de 38,73\% (43/111) de rotavírus do grupo A e 6,3\% (7/111) de rotavírus do grupo D.

- As frequências de ocorrência de rotavírus do grupo A em amostras fecais de aves de acordo com o tipo de criação comercial são de: frangos de corte - 55,81\% (24/43), poedeiras 13,95\% (6/43), matrizes - 18,60\% (8/43) e avós - 2,32\% (1/43), localizadas nos estados de São Paulo, Paraná, Santa Catarina, Rio Grande do Sul e Goiás.

- Definiram-se os genotipos G5, G8, G11, G19 e P[31] a partir das amostras positivas para rotavírus do Grupo A.

- As frequências de ocorrência de rotavírus do grupo D em amostras fecais de aves de acordo com o tipo de criação comercial são de: frangos de corte - 85,71\% (6/7) e matrizes - 14,28\% (1/7) localizadas nos estados de São Paulo, Paraná e Goiás. 


\section{REFERÊNCIAS}

ALAM, M. M.; KOBAYASHI, N.; ISHINO, M.; AHMED, M. S.; AHMED, M. U.; PAUL, S .K.; MUZUMDAR, B. K.; HUSSAIN, Z.; WANG, Y. H.; AND NAIK, T. N. Genetic analysis of an ADRV-N-like novel rotavirus strain B219 detected in a sporadic case of adult diarrhea in Bangladesh. Archives of Virology, v. 152, p. 199-208, 2007.

ALFIERI, A. F.; ALFIEIRI, A. A.; RESENDE, J. S.; RESENDE, M. Atypical rotavirus infections among broiler chickens in Brazil. Arquivo Brasileiro de Medicina Veterinária e Zootecnia, v. 41, p. 81-82, 1989a.

ALFIERI, A. F.; ALFIEIRI, A. A.; RESENDE, M.; RESENDE, J. S. Detection and propagation of avian enteric reovirus in chicken. Arquivo Brasileiro de Medicina Veterinária e Zootecnia, v. 41, p. 493-501, 1989 b.

ALFIERI, A. A.; ALFIERI, A. F.; FREIJAS, J. C.; SILVA, C. A. FREIRE, R. L.; BARROS, A. R.; BARREIROS, M. A. B; MÜLLER, E. E. ocorrência de Escherichia coli, rotavpirus, picobirnavírus e Cryptosporidium parvo em foco de diarreia pós-desmame em suínos. Semina: Ciências Agrárias, v. 15 p. 5-7, 1994.

ALFIERI, A. F.; TAMEHIRO, C. Y.; ALFIERI, A. A. Vírus entéricos de fita dupla, segmentado, em aves: Rotavírus, Reovírus e Picobirnavírus. Semina: Ciências Agrárias, v. 21, n.1, p. 101-113, 2000.

ARIAS, C. F.; ROMERO, P.; ALVAREZ, V.; LOPEZ, S. Trypsin activation pathway of rotavirus infectivity. Journal of Virology, v. 70, p. 5832-5839, 1996.

ARIAS, C. F.; DECTOR, M. A.; SEGOVIA, L.; LOPEZ, T.; CAMACHO, M.; ISA, P.; ESPINOSA, R.; LOPEZ, S. RNA silencing of rotavirus gene expression. Virus Research, v. 102, p. 43-51, 2004.

ASANO, K. M.; GREGORI, F.; SOUZA, S. P.; ROTAVA, D.; OLIVEIRA, R. N.;

VILLARREAL, L. Y.; RICHTZENHAIN, L. J.; BRANDÃO, P. E. Bovine rotavirus in turkeys with enteritis. Avian Disease, v. 55, p. 697-700. 2011.

ATHANASSIOUS, R.; MARSOLAIS, G.; ASSAF, R.; DEA, S.; DESCÔTEAUX, J. P.; DULUDE, S.; MONTPETIT, C. Detection of bovine coronavirus and type A rotavirus in nenonatal calf diarrea and Winter dysentery of cattle in Quebec: evaluation of three diagnostic methods. Canadian Veterinary Journal, v. 35, p. 163-169, 1994. 
BEARDS, G. M.; CAMPBELL, A. D.; COTTRELL, N. R.; PEIRIS, J. S.; REES, N.; SANDERS, R. C.; SHIRLEY, J. A.; WOOD, H. C.; FLEWETT, T. H. Enzyme-linked immunosorbent assays based on polyclonal and monoclonal antibodies for rotavirus detection. Journal of Clinical Microbiology, v. 19, n. 2, p. 248-254, 1984.

BERGELAND, M. E.; MCADARAGH, J. P.; STOTZ, J. Rotaviral enteritis in turkey poults. In Proceedings of the 26th Western Poultry Disease Conference. University of California, Davis, CA, p. 129-130, 1977.

BERNSTEIN, D. I.; SACK, D. A.; ROTHSTEIN, E.; REISINGER, K.; SMITH, V. E.; O'SULLIVAN, D.; SPRIGGS, D. R.; WARD, R. L. Efficacy of live, attenuated, human rotavirus vaccine 89-12 in infants: a randomised placebo-controlled trial. Lancet, v. 354, p. 287-290, 1999.

BEROIS, M.; SAPIN, C.; ERK, I.; PONCET, D.; COHEN, J. Rotavirus nonstructural protein NSP5 interacts with major core protein VP2. Journal of Virology, v. 77, p. 1757-1763, 2003.

BEZERRA, D. A.; SILVA, R. R.; KAIANO, J. H.; SILVESTRE, R. V.; OLIVEIRA, D. S.; LINHARES, A. C.; GABBAY, Y. B.; MASCARENHAS, J. D. Detection of avian group D rotavirus using the polymerase chain reaction for the VP6 gene. Journal of Virology Methods, v. 185, p. 189-192, 2012.

BISHOP, R. F.; DAVIDSON, G. P.; HOLMES, I. H.; RUCK, B. J. Virus particles in epithelial cells of duodenal mucosa from chicken with viral gastroenteritis. Lancet, v. 2, p. 1281-1283, 1973.

BIUTRAGO, L. Y. V. Coronavirus em aves: detecção, caracterização molecular e filogenética e inoculação experimental em aves SPF. 2003. 107 f. Dissertação (Mestrado em Ciências) - Faculdade de Medicina Veterinária e Zootecnia, Universidade de São Paulo, 2003.

BRASIL. MINISTÉRIO DA AGRICULTURA PECUÁRIA E ABASTECIMENTO. Portaria $n^{\circ} 193$, de 19 de setembro de 1994. Institui o Programa Nacional de Sanidade Avícola no âmbito da SDA e cria o Comitê Consultivo do Programa de Sanidade Avícola. Brasília, DF, 1994. Disponível em:

$<$ http://extranet.agricultura.gov.br/sislegisconsulta/consultarLegislacao.do?operacao=visualiz ar\&id=2635>. Disponível em: 7 mar. 2013.

BRUSSOW, H.; NAKAGOMI, O.; GERNA G.; EICHHORN, W. Isolation of anavianlike group A rotavirus from a calf with diarrhea. Journal of Clinical Microbiology, v. 30, p. 6773, 1992. 
CARTER, J. B.; SAUNDERS, V. A. Reoviroses. In: CARTER, J. B.; SAUNDERS, V. A. Virology: principles and applicantions. 3. ed. Liverpool: John Wiley \& Sons, Ltd, 2007. Cap. 13 , p. $147-158$.

CHARPILIENNE, A.; LEPAULT, J.; REY, F.; COHEN, J. Identification of rotavirus VP6 residues located at the interface with VP2 that are essential for capsid assembly and transcriptase activity. Journal of Virology, v. 76, p. 7822-7831, 2002.

COOK, N.; BRIDGER, J.; KENDALL, K.; GOMARA, M. I.; EL-ATTAR, L.; GRAY, J. The zoonotic potential of rotavirus. Journal of Infection, v. 48, p. 289-302, 2004.

DENNEHY, P. H. Rotavirus vaccines: an overview. Clinical Microbiology Reviews, v. 21, p. 198-208, 2008.

DESSELBERGER, U. Genome rearrangements of rotaviruses. Advances in Virus Research, v. 46, p. 69-95, 1996.

DORMITZER, P. R.; GREENBERG, H. B. Calcium chelation induces a conformational change in recombinant herpes simplex virus-1-expressed rotavirus VP7. Virology, v. 189, p. 828-832, 1992.

ESTES, M. K. Rotaviruses and their replication. In: KNIPE, D. M.; HOWLEY, P. M. Fields virology. 4. ed. Philadelphia: Lippincott ,Williams \& Wilkins, 2001. p. 1747-1785.

ESTES, M. K.; KAPIKIAN, A.Z. Rotaviruses. In: KNIPE D. M.; HOWLEY, P. M. (Ed.) Fields Virology. 5. ed. Philadelphia: Lippincott, Williams and Wilkins, 2007. p. 1917-1974.

FAUQUET, C. M.; MAYO, M. A.; MANILOFF, J.; DESSELBERGER, U.; BALL, L. A. (Ed.). The eighth report of the international committee on taxonomy of viruses. San Diego: Elsevier Academic Press, 2005. p. 947-955.

FLEISS, J. L. Statistical methods for rates and proportions. New York: John Wiley, 1981. p 212-236.

FLEWETT, T. H.; BRYDEIV, A. S.; DAVIES, H. A.; WOODE, O. N.; BRINGER, J. C.; DEMCK, J. M. Relation between viruses from acute gastroenteritis of children and new born calves. Lancet, p. 61-63, 1974. 
FLORES, J.; SEARS, J.; GREEN, K. Y.; PEREZ-SCHAEL, I.; MORANTES, A.; DAOUD, G. Genetic stability of rotaviruses recovered from asymptomatic neonatal infections. Jouranl of Virology, v. 62, p. 2778-4781, 1988.

GOUVEA, V.; SANTOS, N.; TIMENETSKY, M. C. Identification of bovine and porcine rotavirus G types by PCR. Journal of Clinical Microbiology, v. 32, n. 5, p. 1338-1340, 1994a.

GOUVEA, V.; SANTOS, N.; TIMENETSKY, M. C. VP4 typing of bovine and porcine group A rotaviruses by PCR. Journal of Clinical Microbiology, v. 32, n. 5, p. 1333-1337, 1994b.

GREEN, K. Y.; SEARS, J. F.; TANIGUCHI, K.; MIDTHUN, K.; HOSHINO, Y.;

GORZIGLIA, M. Prediction of human rotavirus serotype by nucleotide sequence analysis of the VP7 protein gene. Journal of Virology, v. 62, p. 1819-1823, 1988.

GREENBERG, H.; MCAULIFFE, V.; VALDESUSO, J.; WYATT, R.; FLORES, J.; KALICA, A. Serological analysis of the subgroup protein of rotavirus, using monoclonal antibodies. Infect Immun, v. 39, p. 91-99, 1983b.

GREGORI, F.; BRANDÃO, P. E.; ROSALES, C. A. R.; CORTEZ, A.; HEINEMANN, M. B.; RICHTZENHAIN, L.; JEREZ, J. A. Desenvolvimento de um método de ELISA para a detecção de rotavírus a partir de material fecal. Arquivos do Instituto Biológico, v. 67, n. 2, p. 191-194, 2000.

GREGORI, F.; BRANDÃO, P. E.; JEREZ, J. A. Intragenotypic diversity of Porcine Rotavirus strains circulating in São Paulo State, Brazil. ARS Veterinária (Impresso), v. 28, p. 28-35, 2012.

GREIG, S. L.; BERRIMAN, J. A.; O'BRIEN, J. A.; TAYLOR, J. A.; BELLAMY, A. R.; YEAGER, M. J.; MITRA, A. K. Structural determinants of rotavirus subgroup specificity mapped by cryo-electron microscopy. Journal of Molecular Biology, v. 356, p. 209-221, 2006.

HALL, T. A. Bioedit: a user-friendly biological sequence alignment editor and analysis program for windows 95/98/nt. Nucleic Acids Symposium Series, v. 41, p. 95-98, 1999.

HAYNES, J. S.; REYNOLDS, D. L.; FAGERLAND, J. A.; FIX, A. S. Morphogenesis of enteric lesions induced by group D rotavirus in ringneck pheasant chicks (Phasianus colchicus). Veterinary Pathology, v. 31, p. 74-81, 1994. 
HERRING, A. J.; INGLIS, N. F.; OJEH, C. K.; SNODGRASS, D. R.; MENZIES, J. D. Rapid diagnosis of rotavirus infection by direct detection of viral nucleic acid in silver-stained polyacrylamide gels. Journal of Clinical Microbiology, v. 16, n. 3, p. 473, 1982.

INSTITUTO ADOLFO LUTZ. Centro de Vigilância Epidemiológica "Professor Alexandre Vranjac”. Diarreia e rotavírus. Revista de Saúde Pública, v. 38, n. 6, p. 844-845, 2004. Informa técnico institucional. Disponível em <www.fsp.usp.br/rsp>. Acesso em 20 abr. 2012.

JEREZ, J. A. Diarreias virais dos bezerros: rotavírus e coronavírus. Biológico, v. 59, n. 2, p. 33-37, 1997.

JONES, R. C.; HUGHES, C. S.; HENRY, R. R. Rotavirus infection in commercial laying hens. Veterinary Record, v. 104, p. 22, 1979.

KAPIKIAN, A. Z.; HOSHINO, Y.; CHANOCK, R. M. Rotaviruses. In: KNIPE, D. M.; HOWLEY, P. M.; GRIFFIN, D. E.; LAMB, R. A.; MARTIN, M. A.; ROIZMAN, B.; STRAIS, S. E. Fields virology. 4. ed. Philadelphia: Lipincott William and Wilkins, 2001. p. 1787-1833.

KARIM, M. R.; RUME, F. I.; ALAM, M. M.; AHMED, U. Molecular epidemiologic study on avian rotavirus prevailing in Bangladesh. Bangl. Journal of Veterinary Medicine, v. 5, p. 43-48, 2007.

KING, A. M. Q.; ADAMS, M. J.; CARSTENS, E. B.; LEFKOWITZ, E. J. (Ed.). Virus Taxonomy: classification and nomenclature of viruses. 9. ed. San Diego: Elsevier Academic Press, 2012. 1272 p.

KOOPMANS, M.; DUIZER, E. Foordborne viruses: an emerging problem. International Journal of Food Microbiology, n. 90, p. 23-41, Mar., 2004.

LANDIS, J. R.; KOCH, G.G. The measurement of observer agreement for categorical data. Biometrics, v. 33, p. 159-174, 1977.

LARKIN, M. A.; BLACKSHIELDS, G.; BROWN, N. P.; CHENNA, R.; MCGETTIGAN, P. A.; MCWILLIAM, H.; VALENTIN, F.; WALLACE, I. M.; WILM, A.; LOPEZ, R.; THOMPSON, J. D.; GIBSON, T. J.; HIGGINS, D. G. Clustal W and Clustal X version 2.0. Bioinformatics, v. 23, p. 2947-2948, 2007.

LARRALDE, G.; LI, B. G.; KAPIKIAN, A. Z.; GORZIGLIA, M. Serotype-specific epitope(s) present on the VP8 subunit of rotavirus VP4 protein. Journal of Virology, v. 65, n. 6, p. 3213-328, 1991. 
LOPES, J. E. P. Análise econômica de contratos de integração usados no complexo agroindustrial avícola brasileiro. 1992. 105 f. Dissertação (Mestrado em Economia Rural) Universidade Federal de Viçosa, Visçosa, 1992.

MACKOW, E. R.; SHAW, R. D.; MATSUI, S. M.; VO, P. T.; BENFIELD, D. A.; GREENBERG, H. B. Characterization of homotypic and heterotypic VP7 neutralization sites of rhesus rotavirus. Virology, v. 165, n. 2, p. 511-517, 1988.

MAES, P.; MATTHIJNSSENS, J.; RAHMAN, M.; VAN RANST, M. RotaC: A web-based tool for the complete genome classification of group A rotaviruses. BMC Microbiol , v. 9, p. $238,2009$.

MARTELLA, V.; BANYAI, K.; MATTHIJNSSENS, J.; BUONAVOGLIA, C.; CIARLET, M. Zoonotic aspects of rotaviruses. Veterinary Microbiology, v. 140, p. 246-255, 2010.

MASCARENHAS, J. D. P. Caracterização molecular de genotipos de rotavírus do grupo A em Belém, Pará, no período de 1990 a 2003: estudo em neonatos, crianças diarreicas de 0-3 anos e ensaio clínico com vacinas. 2006. Tese (Doutorado em Biologia Parasitária) Instituto Oswaldo Cruz, Fundação Oswaldo Cruz, São Paulo, 2006.

MATTHEWS, R. E. "Third report of the international committee on taxonomy of viruses. classification and nomenclature of viruses". Intervirology, v. 12, p. 129-296, 1979.

MATTHIJNSSENS, J.; CIARLET, M.; RAHMAN, M.; ATTOUI, H.; BÁNYAI, K.; ESTES, M. K.; GENTSCH, J. R.; ITURRIZA-GÓMARA, M.; KIRKWOOD, C. D.; MARTELLA, V.; MERTENS, P. P.; NAKAGOMI, O.; PATTON, J. T.; RUGGERI, F. M.; SAIF, L. J.; SANTOS, N.; STEYER, A.; TANIGUCHI, K.; DESSELBERGER, U.; VAN RANST, M. Recommendations for the classification of group A rotaviruses using all 11 genomic RNA segments. Archives of Virology, v. 153, p. 1621-1629, 2008.

MATTHIJNSSENS, J.; OTTO, P.; CIARLET, M.; DESSELBERGER, U.; VAN RANST, M.; JOHNE, R. VP6 sequence-based cut-off values as a criterion for rotavirus species demarcation. Archives of Virology, v. 157, p. 1177-1182, 2011.

MATTION, N.; COHEN, J.; ESTES, M. The rotavirus proteins. In KAPIKIAN, A. Z. (Ed.) Viral infectious of gastrointestinal tract. New York: Marcel Dekker, 1994, p. 169-249.

MEBUS, C. A.; Underdahl, N. R.; Rhodes, M. B.; Twiehaus, M. J. Calf diarrhea (Scours): reproduced with a virus from a field outbreak. Nebraska Res. Bull, v. 233, 1969. 
MCNULTY, M. S. Rotaviruses. Journal of General Virology, v. 40, p. 1-18, 1978.

MCNULTY, M. S.; ALLAN, G. M.; TODD, D.; MCFERRAN, J. B. Isolation and cell culture propagation of rotaviroses from turkeys and chickens. Archives of Virology, v. 61, p. 13-21, 1979a.

MCNULTY, M. S.; CURRAN, W. L.; TODD, D.; MCFERRAN, J. B. A Detection of viruses in avian faeces by direct eléctron microscopy. Avian Pathology, v. 8, n.3, p. 239-247, 1979b.

MCNULTY, M. S., D. TODD, G. M. ALLAN, J. B. MCFERRAN, AND J. A. GREEN. Epidemiology of rotavirus infection in broiler chickens: recognition of four serogroups. Archives of Virology, v.81, p. 113-121, 1984.

MCNULTY, M. S. Rotavirus infections. In: SAIF, Y. M.; BARNES, H. J.; GLISSON, J. R.; FADLY, A. M.; McDOUGALD, L. R.; SWAYNE, D.E. Diseases of poultry. 11 ed. Ames: Iowa State University Press, 2003. p. 308-317.

MORI, Y.; SUGIYAMA, M.; TAKAYAMA, M.; ATOJI, Y.; MASEGI, T.; MINAMOTO, N. Avian-tomammal transmission of an avian rotavirus: analysis of its pathogenicity in a heterologous mouse model. Virology, v. 288, p. 63-70, 2001.

MCDONALD, S. M.; PATTON, J. T.. Molecular characterization of a subgroup specificity associated with the rotavirus inner capsid protein VP2. Journal of Virology, v. 82, p. 27522764, 2008.

OGDEN, K. M.; JOHNE, R.; PATTON, J. T. Rotavirus RNA polymerases resolve into two phylogenetically distinct classes that differ in their mechanism of template recognition.

Virology, v. 431, p 50-57, 2012.

OTTO, P.; AHMED, M. U.; HOTZEL, H.; MACHNOWSKA, P.; REETZ, J.; ROTH, B.; TROJNAR, E.; JOHNE, R. Detection of avian rotaviruses of groups A, D, F and G in diseased chickens and turkeys from Europe and Bangladesh. Veterinary of Microbiology, v. 156, p. 8-15, 2012.

PAHO. PAN AMERICAN HEALTH ORGANIZATION. Rotaviral gastroenteritis. In: Zoonoses and communicable diseases common to man and animals: chlamydioses, rickettsioses and viroses. 3. ed. Washington: PAHO, 2001. p. 286-294. 
PARK, S. H.; SAIF, L. J.; JEONG, C.; LIM, G. K.; PARK, S. I.; KIM, H. H.; PARK, S. J.; KIM, Y. J.; JEONG, J. H.; KANG, M. I.; CHO, K. O. Molecular characterization of novel G5 bovine rotavirus strains. Journal of Clinical Microbiology, v. 44, n. 11, p. 4101-4112, 2006.

PARASHAR, U. D.; ALEXANDER, J. P.; GLASS, R. I. Prevention of rotavirus gastroenteritis among infants and children. Recommendations of the Advisory Committee on Immunization Practices (ACIP). MMWR Recommendations and Reports, v. 55, p.1-13, 2006.

PARRA, G. I.; BOK, K.; MARTÍNEZ, M., GOMEZ, J. A. Evidence of rotavirus intragenic recombination between two sublineages of the same genotype. Journal of General Virology, v. 85, n. 6, p. 1713-16, 2004.

PARRA, G. I.; VIDALES, G.; GOMEZ, J. A.; FERNANDEZ, F. M.; PARREÑO, V.; BOK, K. Phylogenetic analysis of porcine rotavirus in Argentina: increasing diversity of G4 strains and evidence of interspecies transmission. Veterinary Microbiology, v. 126, n.1-3, p. 24350, 2008.

PATTON, J. T.; SALTER-CID, L.; KALBACH, A.; MANSELL, E. A.; KATTOURA, M. Nucleotide and amino acid sequence analysis of the rotavirus nonstructural RNA-binding protein NS35. Virology, v. 192 p. 438-446, 1993.

PATTON, J. T.; VASQUEZ-DEL CARPIO, R.; TORTORICI, M. A.; TARAPOREWALA, Z. F. Coupling of rotavirus genome replication and capsid assembly. Advances in Vírus Research, v. 69, p. 167-201, 2007.

PEDLEY, S., J. C. BRIDGER, D. CHASEY, AND M. A. MCCRAE. Definition of two new groups of atypical rotaviruses. Journal of General Virology, v. 67, p. 131-137, 1986.

PORTER, R. E. Bacterial enteritis of poultry. Poultry Science, v. 7, n. 8, p. 1159-1165, 1998.

RAINSFORD, E. W.; MCCRAE, M. A. Characterization of the NSP6 protein product of rotavirus gene 11. Virus Research, v. 130, p. 193-201, 2007.

RAMIG, R. F., CIARLET, M.; MERTENS, P. P. C.; DERMODY, T. S. Genus Rotavirus. In: INTERNACIONAL COMMITTEE ON TAXONOMY OF VIRUSES, 8., 2005, New York. Virus taxonomy. Eighth report of the ICTV. New York: Elsevier Academic Press, 2005. P. 484-496. 
RATCLIFF, R. M.; CHANG, G.; KOK, T.; SLOOTS, T. P. Molecular diagnosis of medical viruses. Current Issues in Molecular Biology, v. 9, p. 87-102, 2007

ROHWEDDER, A.; SCHÜTZ, K. I.; MINAMOTO, N.; BRÜSSOW, H. Sequence analysis of pigeon, turkey, and chicken rotavirus VP8* identifies rotavirus 993/83, isolated from calf feaces, as a pigeon rotavirus. Virology, v. 210, p. 231-235, 1995.

RIOS, R. L.; MARIN, S. Y.; GOMES, A. M.; RESENDE, J. S.; BONFIM, M. R. Q.; GOMES, A. D.; RESENDE, F. M. S.; HORTA, R. S.; RESENDE, M.; MARTINS, N. R. S. The occurrence of Orthoreovirus, Rotavirus and chicken anemia virus in chickens of the poultry industry in Minas Gerais, Brazil. Arquivo Brasileiro de Medicina Veterinária e Zootecnia, v. 64, n. 6, p. 1613-1620, 2012.

SAIF, L. J.; SAIF, Y. M.; THEIL, K. W. Enteric viruses in diarrheic turkey poults. Avian Disease, v. 29, p. 798-811, 1985.

SALEM, A. N. B.; SERGEI, A. C.; OLGA, P. B.; OLGA, G. A.; MAHJOUB, A.; LARISSA, B. P. Multiplex nested RT-PCR for the detection of porcine enteric viruses. Journal of Virological Methods, v. 165, n. 2, p. 283-293, 2010.

SCHUMANN, T.; HOTZEL, H.; OTTO, P.; JOHNE, R. Evidence of interspecies transmission and reassortment among avian group A rotaviruses. Virology, v. 386, p. 334343, 2009.

SILVA, L. C.; SANCHE, A. A.; GREGORI, F.; BRANDÃO, P. E.; ALFIERI, A. A.; HEADLEY, S. A.; JEREZ, J. A. First description of group A rotavirus from fecal samples of ostriches (Struthio camelus). Research Veterinary Science, v. 93, p. 1066-1069, 2012.

TAMEHIRO, C. Y.; ALFIERI, A. F.; MEDICI, K. C.; ALFIERI, A. A. Segmented doublestranded genomic RNA viruses in fecal samples from broiler chicken. Brazilian Journal of Microbiology, v. 34, n. 4, 2003.

TAMURA, K.; PETERSON, D.; PETERSON, N.; STECHER, G.; NEU, M.; KUMAR, S. MEGA5: molecular evolutionary genetics analysis using maximum likelihood, evolutionary distance, and maximum parsimony methods. Molecular Biology Evolucionary, v. 28, n.10, p. 2731-2739, 2011.

TANIGUCHI, K.; URASAWA, S. Diversity in rotavirus genomes. Seminars in Virology, v. 6, p. 123-131, 1995. 
TARAPOREWALA, Z. F.; PATTON, J. T. Identification and Characterization of the HelixDestabilizing Activity of Rotavirus Nonstructural Protein NSP2. Journal of Virology, v. 75, n. 10, p. 4519-4527, 2001.

THEIL, K. W.; SAIF, L. J. Age-related infections with rotavirus, rotavirus-like vírus, and atypical rotavirus in turkey flocks. Journal of Clinical Microbiology, v. 25, p. 333-337, 1987.

TROJNAR, E.; OTTO, P.; ROTH, B.; REETZ, J.; JOHNE, E. The genome segments of a group D rotavirus possess group A-like conserved termini but encode group-specific proteins. Journal of Virology, v. 84, p. 10254-10265, 2010.

TROJNAR, E.; SACHSENRÖDER, J.; TWARDZIOK, SVEN.; JOCHEN, R.; OTTO, P. H.; JOHNE, R. Identification of an avian group A rotavirus containing a novel VP4 gene with a close relationship to those of mammalian rotaviroses. Journal of General Virology, v. 94, p. 136-142, 2013.

UBABEF - ASSOCIAÇÃO BRASILEIRA DOS EXPORTADORES DE FRANGO.

Relatórios 2012. Disponível em: 〈http://www.abef.com.br/uba/sanidade_avicola/pnsa〉. Disponível em: 6 mar. 2011.

VILLARREAL, L. Y. B.; ULIANA, G.; VALENZUELA, C.; CHACÓN, J. L. V.; SAIDENBERG, A. B. S.; SANCHES, A. A.; BRANDÃO, P. E.; JEREZ, J. A.; FERREIRA, A. J. P.Rotavirus detection and isolation from chickens with or without symptoms. Revista Brasileira de Ciência Avicola, v. 8, n. 3, 2006.

WALTER, R. Umweltvirologie. Viena: Springer-Verlag Wien, 2001. 266 p.

WARD, R. L. Possible mechanisms of protection elicited by candidate rotavirus vaccines as determined with the adult mouse model. Viral Immunology, v. 16, p.17-24, 2003.

WILSON, I. G. Inhibition and facilitation of nucleic acid amplification. Applied Environmental Microbiology, n. 63, v. 10, p. 3741-3751, 1997.

WINIARCZYK, S.; GRADZKI, Z. Comparison of polymerase chain reaction and dot hybridization with enzyme-linked immunoassay, virological examination na polyacrylamide gel electrophoresis for the detection of porcine rotavirus in faecal specimens. Journal of Veterinary Medicine, Series B, v. 46, n. 9, p. 623-634, 2002. 
YASON, C .V.; SCHAT, K. A. Pathogenesis of rotavirus infection in various age groups ag chickens and turkeys: clinical signs and virology. Am. J. Res, v. 48, p. 977-983, 1987

ZHANG, M.; ZENG, C.Q.; DONG, Y. Mutations in rotavirus nonstructural glycoprotein NSP4 are associated with altered virus virulence. Journal of Virology, v. 72, p. 3666-3672, 1998. 
APÊNDICE A

As sequências nucleotídicas parciais de NSP5 de rotavírus aviário do grupo A geradas no presente estudo encontram-se relacionadas abaixo:

$>$ NSP5 4

GGTGAGTGGATCGTTTGAAGCAGAATCAGATGGTCCAATATCTTCTGGAGACTTT GACAGCATGTATTTACTGAATGCTTCTGCATCTGGTGAAATGTATTGTTCACTCCT ACCAATAGATTTTCCAGAAAGAGTTGACGTTGTTGAAGATGATTCATTTTTGTATA TACTAGAAGAAATAGAAGGAAGACTCGTCACGTCAATACTGAGAGACAT

>NSP5 30

TGAGTGGATCGTTTGAAGCAGAATCAGATGGTCCAATTTCGTCTGGAGACTTCGA CAGCATGTATTTACTGAATGCTTCTGCATCTGGTGAAATGTATTGTTCACTCCTAC CAATAGATTTTCCAGAAAGAGTTGACGTTGTTGAAGATGATTCATTTTTGAATAT ACTAGAAGAAATTGAAGGAAGACTCGTTACGTCAATGCTGAGA

>NSP5 32

TTGAGTGGATCGTTTGAAGCAGAATCAGATGGTCCAATATCTTCTGGAGACTTTG ACAGCATGTATTTACTGAATGCTTCTGCATCTGGTGAAATGTATTGTGACTCCTAC CAATAGATTTTCCAGAAAGAGTTGACGTTGTTGAAGATGATTCATTTTTGTATATA CTAGAAGAAATAGAAGGAAGACTCGTTACGTCAATGCTGAGA

As sequências nucleotídicas parciais de VP7 de rotavírus aviário do grupo A geradas no presente estudo encontram-se relacionadas abaixo:

>USPARV05 (NÚMERO DE ACESSO KC962122)

CTTTGTTTAGTTACCGGGAAGTGTACTATCCTTTCTATTGAGATAATATTCTACTTT ATTGTAGTATTATTAATTTATGATATTATTCATAGAATGGCTAGCTCATATGTTTT CTGCATTAGTGTTTTCATTATTACTGTCACTATTCTACCACGTTGTTATGCTCAAA ATTATGGGGTTAATGTTCCAATTACAGGATCGTTAGACGTTACCATACAGAATCA AACAGTTGAGCCAATTGGCCTAACGTCAACTTTGTGTTTATATTATCCAGCGGAA 
GCATCAACAGAAATAGCTGATACTGAATGGAAACAGACCATAAGTCAGTTATTTT TAACTAAGGGATGGCCAACGACTTCAATTTACTTTAATGAGTATCAAGATTTGCA AACGTTTTCGAATAATCCGAATATAAATTGTGATTATAATATAATATTAATAAAA TATGATGGAAATCAAGGACTAGATATTTCAGAAATTGCTGAACTACTTTTATATG AATGGTTGTGCAATGAAATGGATATTAGTTTGTATTATTATCAACAGACTTCAGA GGCTAATAAATGGATAGCGATGGGCACAGATTGTACAGTTAAAGTATGTCCACTA AATACTCAAACATTAGGAATTGGCTGCAAGACTACCGATGTTTCCACTTTTGAAC AGCTAACGGCTACAGAAAAATTGGCCATTATTGATGTTGTTGACGGCGTTAGTCA TAAAATAGATTATACTGTAACGACTTGTAACGTTAAAAATTGTATGCGACTAAAC CAGCGCGAAAATGTAGCGATAATACAAGTTGGTGGACCAGAGATTATTGATGTTT CAGAAGATCCAATGGTGGTGCCAAAAATGCAGCGCG

>USPARV06 (NÚMERO DE ACESSO KC962123)

TTAATTTATGATATTATTCATAGAATGGCTAGCTCATATGTTTTCTGCATTAGTAT TTTCATTATTACTGTCACTATTCTACCACGTTGTTATGCTCAAAATTACGGGGTTA ATGTTCCAATCACAGGATCGTTAGATGTTACTGTACAGAATCAAACAGTTGAACC AATTGGATTAACGTCAACTTTATGTTTATATTATCCAGCAGAAGCATCAACAGAA ATAGCTGATACTGAATGGAAGCAGACCATGAGCCAGCTATTTTTAACCAAGGGAT GGCCAACGACTTCAATTTACTTTAATGAATATCAAGATCTACAAACGTTTTCGAA TAATCCAAGTATAAATTGTGATTATAATATAATACTAATAAAATATGACGCAAAT CAAGGATTAGATATTTCAGAGATTGCTGAGCTACTTTTATATGAATGGCTGTGCA ATGAAATGGATATTAGTTTGTATTATTACCAACAGACTTCAGAGGCTAATAAATG GATAGCGATGGGTACAGATTGTACAGTCAAAGTATGTCCACTAAATACTCAAACA TTAGGAATTGGCTGCAAGACTACTGATGTTTCTACTTTTGAACAGTTAACAACTAC AGAAAAATTGGCTATCATTGACGTTGTTGACGGCGTTAATCACAAAATAGACTAT ACTCTAACAACTTGTAACGTTAAAAATTGTATACGACTAAATCAGCGCGAAAATG TAGCGATAATACAAGTTGGTGGACCAGAGATCATTGATGTTTCAGAAGATCCAAT GGTTGTGCCCAAAATGCAACGCG

As sequências nucleotídicas parciais de VP4 de rotavírus aviário do grupo A geradas no presente estudo encontram-se relacionadas abaixo: 
>USPARV01 (NÚMERO DE ACESSO KC962114)

TTTGGCTTTCGCTTCATTTATAGACAACTTTTAGCGAATTCTTACACTTCAGATTTA CAGGACGATATTGAtGATATTTCTGCTGAGAAAACACAAGGAGTAACAATTAATC CGGGGCCTTTTGCCCAGACAGGTTATGCTCCAGTGGAATGGACTCATGGGGATAT ACCAGTCGATGAAACAATTGAACCAACACTTGATGGACCATATTCAGCTTCATCA ATTGTAATTCAACCACAATATTGGATATTAGTGAATCCAACAAATCAAGACGTCG TGATTGAAGCCGACGCGCAGAACAAGAAATTTGCTTGCGTTATGTTACCACCTAA TACTCCTGAATCAGATAAACAGTACATAATATTAGGTAAACAGATAACGATTAGA TTAGGTAATACTGATGCTGTGAATTATAAATTTTGTGATTTACTCAGTAATGATGG AATAACTTACACTAAATCAATAGAACTAGTTACTCCACATCGCTTAAATGCATTT ATGAAAGACGCTGGTAAATTATATGCATACAGTGGTACTATGCCAACAATAAAA AGAGAGTACCATACGTTAGATAATATTGAAAATGTACAAACCAATATAACATGTG AGTATTACATAGTACCTAATAGCCAAGTAAGCACGCTAGAGGAATATTTAAAGA ATGGATTACCACCAATTCAACAAACGCGTTATTTACTTCCAGTCGCTCGAAGTGTT GCAAACATATATCGTGCTAAGCCAAACGAAGATATATTAAGTGTCAAAACTTCTT TATGGAAAGAAATGCAATA

>USPARV02 (NÚMERO DE ACESSO KC962115)

TTCATTTATAGACAACTTTTAGCCAATTCATATACTTCAGATTTGCAAGATAATAT TGATGATATCTCTGCTGAAAAGACTCAAGGAGTAACAATTAATCCAGGACCTTTT GCCCAAACAGGTTATGCACCAGTAGAATGGACACATGGGGATATACCAGTTGAT GAAACAATTGAACCAACGCTTGATGGACCTTACTCTGCTTCTTCAATTGTTATACA GCCACAGTATTGGATATTAGTGAATCCAACAACTCAAGATGTTGTTATTGAAGCT GATACGCAAAATAAAAAGTTTGCCTGTATTTTATTGCCACCAAATACACCAGAAT CTGCTAAGCAATATGTAATTTTAGGTAAACAAGTAACAATTATACTAGGTAATCC TGATAAAATGAATTACAAATTTTGTGATTTATTGAGTAATGATGGCGTGACTTAT ACAAAATCAATAGAACTTATTACTCCACATCGTCTGAATGCATTTATGAAGGATG CTGGTAAATTATATGCATATAGCGGTACAGTGCCAACAATTAAAAGAGAATATCA TGTACTAGACAATATAGAAAATGTACAAACTAACATAAAATGCGAGTACTATATA GTACCGAATAGTCAAGTAAATACATTAGAAGAATATTTAAAGAATGGCCTGCCAC CTATTCAACAAACCCGTTATTTAATGCCAGTCGCTCAAAATACTATGAATTCATAT CGCGCGAAACCCAATGAAGATATAGTAATATCGAAGACTTCATTATGGAAAGAA ATGCAATATAATAGAGACATAACTATAAGGTTTAAGTT 
>USPARV03 (NÚMERO DE ACESSO KC962116)

TATAGACAACTTTTAGCCAATTCATATACTTCAGATTTGCAAGATAATATTGATGA TATTTCTGCTGAAAAGACTCAAGGAGTAACAATTAATCCAGGACCTTTTGCTCAA ACAGGTTATGCACCAGTAGAATGGACGCATGGGGATATACCAGTTGATGAAACA ATTGAACCAACGCTTGATGGACCTTATTCTGCTTCTTCAATTGTTATACAGCCACA GTATTGGATATTAGTGAATCCAACAACCCAAGATGTTGTTATTGAAGCTGATACA CAAAATAAAAAGTTTGCTTGTATTTTATTGCCACCAAATACACCAGAATCTGCTA AGCAATATGTAATTTTAGGTAAACAAGTAACAATTATACTGGGTAATCCTGATAA AATGAATTATAAGTTTTGTGATTTATTAAGTAATGATGGCGTGAATTATACAAAA TCAATAGAACTTACTACTCCACATCGTCTGAATGCGTTTATGAAGGATGCTGGTA AATTATATGCATATAGCGGTACAGTGCCAACAATTAAAAGAGAATATCATGTACT AGATAATATAGAAAATGTGCAAACTAACATAAAGTGTGAGTACTATATAGTACC GAATAGTCAAGTAAATACATTAGAAGAATATTTAAAGAACGGCCTGCCACCTATT CAACAAACACGTTATTTAATGCCAGTCGCTCATTTTACTATGAATTCATATCGCGC GAAACCTAATGAGGATATAGTAATATCGAAGACCTCATTATGGAAAGAAATGCA ATAT

>USPARV04 (NÚMERO DE ACESSO KC962117)

CCAGGACCTTTTGCTCAAACAGGTTATGCACCAGTAGAATGGACGCATGGGGATA TACCAGTTGATGAAACAATTGAACCAACGCTTGATGGACCTTATTCTGCTTCTTCA ATTGTTATACAGCCACAGTATTGGATATTAGTGAATCCAACAACCCAAGATGTTG TTATTGAAGCTGATACACAAAATAAAAAGTTTGCTTGTATTTTATTGCCACCAAAT ACACCAGAATCTGCTAAGCAATATGTAATTTTAGGTAAACAAGTAACAATTATAC TGGGTAATCCTGATAAAATGAATTATAAGTTTTGTGATTTATTAAGTAATGATGG CGTGAATTATACAAAATCAATAGAACTTACTACTCCACATCGTCTGAATGCGTTT ATGAAGGATGCTGGTAAATTATATGCATATAGCGGTACAGTGCCAACAATTAAAA GAGAATATCATGTACTAGATAATATAGAAAATGTGCAAACTAACATAAAGTGTG AGTACTATATAGTACCGAATAGTCAAGTAAATACATTAGAAGAATATTTAAAGAA CGGCCTGCCACCTATTCAACAAACACGTTATTTAATGCCAGTCGCTCATTTTACTA TGAATTCATATCGCGCGAAACCTAATGAGGATATAGT

>USPARV05 (NÚMERO DE ACESSO KC962118)

GAATGGACTCATGGGGATATACCAGTCGATGAAACAATTGAACCAACACTTGAC GGACCATATTCAGCTTCATCAATTGTAATTCAGCCACAATATTGGATATTAGTAA 
ATCCAACAAATCAAGAAGTAGTGATTGAAGCCGACGCGCAGAACAAGAAATTTG CTTGTGTTATGTTACCACCTAATACTCCTGAATCCGATAAACAGTACATGATATTA GGTAAACAAATAACGATTAGATTAGGTAATCCCGACGCTGTGAATTATAAATTCT GCGATTTGCTAAGTAATGATGGAATAACTTATACTAAATCAATAGAACTAGTCAC TCCGCACCGCTTAAATGCATTTATGAAAGACGCTGGTAAATTATATGCATATAGT GGCACTGTGCCAATAATAAAAAGAGAGTACCATACGTTAGATAACATAGAAAAT GTACAAACTAACATAACATGTGAGTATTACATAGTACCGAATAGCCAAGTGAGC ACGCTAGAGGAATATTTAAAAAATGGATTACCACCAATTCAACAAACGCGTTATT TACTTCCAGTCGCTCGAAGTGTTGCAAATCTATATCGTGCTAAACCAAACGAAGA TATATTAGTGTCGAAAACTTCTTTATGGAAAGAAATGCAATATAATAGGGACATA ACAATACG

>USPARV06 (NÚMERO DE ACESSO KC962119)

GAATGGACTCATGGGGATATACCGGTCGATGAAACAATTGAACCAACACTTGAT GGACCATATTCAGCTTCATCAATTGTAATTCAACCACAATATTGGATATTAGTAA ATCCGACAAATCAAGAAGTAGTGATTGAAGCTGACGCGCAGAATAAGAAATTTG CTTGTGTTATGTTACCACCTAATACTCCTGAATCCGATAAACAGTACATGATATTA GGTAAACAGATAACGATTAGATTAGGTAATACCGATGCTGTAAATTATAAATTTT GTGATTTGCTAAGTAATGATGGAATAACTTACACTAAATCAATAGAACTAGTCAC TCCACATCGCCTAAATGCATTTATGAAAGATGCTGGTAAATTATATGCATATAGT GGTATTGTACCAACAATAAAAAAAGAGTACCATACGTTAGATAACATAGAAAAT GTACAAACTAACATAACATGTGAGTATTACATAGTACCGAATAGCCAAGTGAGC ACACTAGAGGAATATTTAAAAAATGGATTACCACCAATTCAACAAACGCGCTATT TACTTCCAGTTGCCCGAAGTGTTACAAATCTATACCGTGCTAAACCAAATGAAGA TATATTAGTGTCAAAAACTTCTTTATGGAAAGAAATGCAATATAATAGGGACATA ACAATACG

>USPARV07 (NÚMERO DE ACESSO KC9621120)

ATATTAGGTAAACAAATAACGATTAGATTAGGTAATCCCGACGCTGTGAATTATA AATTCTGCGATTTGCTAAGTAATGATGGAATAACTTATACTAAATCAATAGAACT AGTCACTCCGCACCGCTTAAATGCATTTATGAAAGACGCTGGTAAATTATATGCA TATAGTGGCACTGTGCCAATAATAAAAAGAGAGTACCATACGTTAGATAACATA GAAAATGTACAAACTAACATAACATGTGAGTATTACATAGTACCGAATAGCCAA GTGAGCACGCTAGAGGAATATTTAAAAAATGGATTACCACCAATTCAACAAACG 
CGTTATTTACTTCCAGTCGCTCGAAGTGTTGCAAATCTATATCGTGCTAAACCAAA CGA

>USPARV08 (NÚMERO DE ACESSO KC962121)

CCAGGACCTTTTGCCCAAACAGGTTATGCACCAGTAGAATGGACACATGGGGATA TACCAGTTGATGAAACAATTGAACCAACGCTTGATGGACCTTACTCTGCTTCTTCA ATTGTTATACAGCCACAGTATTGGATATTAGTGAATCCAACAACTCAAGATGTTG TTATTGAAGCTGATACGCAAAATAAAAAGTTTGCCTGTATTTTATTGCCACCAAA TACACCAGAATCTGCTAAGCAATATGTAATTTTAGGTAAACAAGTAACAATTATA CTAGGTAATCCTGATAAAATGAATT

As sequências nucleotídicas parciais de VP6 de rotavírus aviário do grupo D geradas no presente estudo encontram-se relacionadas abaixo:

>AVRVBR1 (NÚMERO DE ACESSO KC689306)

TTGACTGTTAGAGAAGCACGAGAAAAAATCATAAACGGAACAATATATTCCAAC GTATCAGATGTGATACAGCAATTCAATCAGATGGTTAGAGTATTGAATGGATCAA CTTTTACTACTGGTGGATTAGCTACTATGCCACTTAGAGAATGGACTTTTGATTTG CCGCAGCTAGGTaCAACTCTACTAAATATAGATGCTAACTATGTAGAATCAATGA CACCAACTCTCGATATGTTGACTGAATTTGTGATTGCTGTATGTGAAACCGAATTG TTGATTGATAACAATAGAAATGGTGCATATCCACAATCTGAGGCACTGAGACTAC TGTCTAATAATAAGTATGTTTTCCTTAATATGGATTTAGGATCTAAGTATATTTCA GAATGGCATTATAGATTGTCAGCTAGAGATCCAATGTTTTCAAATCATGTACCAT ACATATTTCCATATGATATGGCTATAGCATATGATAGGGTAACGGCTGCTTATGA CAATGTATCAGGAACCAGATTTGCATCACTGAATAACGCTATACATTTTGCTGCA TTTGATCAAGACTTTGTTCGTGGGCAGCCAGCCAACGCGAGACAATTCGAGTACC TTTATAATTTGAGAACACCAGTGTCTAATGCTACTATTGTTATACATCCAATATCA GACATTCTATCGGTACCGAGTATGATTAGAAATCA

> AVRVBR2 (NÚMERO DE ACESSO KC689307) TTGACTGTCAGAGAAGCACGAGAAAAGATCATAAACGGAACAATATATTCCAAC GTGTCAGATGTGATACAACAATTTAATCAGATGGTTAGAGTATTGAATGGATCAA CTTTTACTACTGGTGGATTGGCTACTATGCCACTCAGAGAATGGACTTTTGATTTG CCGCAGTTAGGTACGACTCTACTAAATATAGATGCTAACTATGTAGAATCAATGA 
CACCAACTCTCGACATGCTGACTGAATTTGTGATTGCCGTATGTGAAACCGAATT GTTAGTTGATAATAACAGAAATGGTGCGTATCCACAATCTGAGGCACTGAGATTA CTGTCTAATAATAAGTACGTTTTTCTTAATATGGATTTAGGATCTAAGTACATTTC AGAATGGCATTATAGATTGTCAGCTAGAGATCCAATGTTTTCAAACCATGTACCA TATATATTTCCATATGATATGGCTATAGCATATGATAGGGTAACGGCCGCTTACG ATAATGTATCAGGAACACGATTTGCATCACTGAATAACGCAATACATTTTGCTGC ATTTGATCAAGACTTTGTTCGTGGGCAGCCAGCTAATGCGAGACAATTCGAATAC CTTTATAATTTGAGAACACCGGTGTCTAATGCTACTATTGTCATACATCCAATATC AGACATTCTATCAGTACCGAGTATGATTAGAAATCA

>AVRVBR3 (NÚMERO DE ACESSO KC689308)

TTGACTGTCAGAGAAGCACGAGAAAAGATCATAAACGGAACAATATATTCCAAC GTGTCAGATGTGATACAACAATTTAATCAGATGGTTAGAGTATTGAATGGATCAA CTTTTACTACTGGTGGATTGGCTACTATGCCACTCAGAGAATGGACTTTTGATTTG CCGCAGTTAGGTACGACTCTACTAAATATAGATGCTAACTATGTAGAATCAATGA CACCAACTCTCGACATGTTGACTGAATTTGTGATTGCCGTATGTGAAACCGAATT GCTAGTTGATAATAACAGAAATGGCGCGTATCCACAATCTGAGGCACTAAGATTA CTGTCTAATAATAAGTACGTTTTTCTTAATATGGATTTAGGATCTAAGTACATTTC AGAATGGCATTATAGATTGTCAGCTAGAGATCCAATGTTTTCAAACCATGTACCA TATATATTTCCATATGATATGGCTATAGCATATGATAGGGTAACGGCCGCCTACG ACAATGTATCAGGAACACGATTTGCATCACTAAATAACGCAATACATTTTGCTGC ATTTGACCAAGACTTTGTTCGTGGGCAGCCAGCCAATGCGAGACAATTCGAATAC CTTTATAATTTGAGAACACCGGTGTCTAATGCTACTATTGTCATACATCCAATATC AGACATT

>AVRVBR4 (NÚMERO DE ACESSO KC689309)

TTGACTGTCAGAGAAGCACGAGAAAAGATCATAAACGGAACAATATATTCCAAC GTGTCAGATGTGATACAACAATTTAATCAGATGGTTAGAGTATTGAATGGATCAA CTTTTACTACTGGTGGATTGGCTACTATGCCACTCAGAGAATGGACTTTTGATTTG CCGCAGTTAGGTACGACTCTACTAAATATAGATGCTAACTATGTAGAATCAATGA CACCAACTCTCGACATGTTGACTGAATTTGTGATTGCCGTATGTGAAACCGAATT GCTAGTTGATAATAACAGAAATGGCGCGTATCCACAATCTGAGGCACTAAGATTA CTGTCTAATAATAAGTACGTTTTTCTTAATATGGATTTAGGATCTAAGTACATTTC AGAATGGCATTATAGATTGTCAGCTAGAGATCCAATGTTTTCAAACCATGTACCA 
TATATATTTCCATATGATATGGCTATAGCATATGATAGGGTAACGGCCGCCTACG ACAATGTATCAGGAACACGATTTGCATCACTAAATAACGCAATACATTTTGCTGC ATTTGACCAAGACTTTGTTCGTGGGCAGCCAGCTAATGCGAGACAATTCGAATAC CTTTATAATTTAAGAACACCGGTGTCTAATGCTACTATTGTCATACATCCAATATC AGACATTCTATCAGTACCGAGTATGATTAGAAATCA 


\section{APÊNDICE B}

O alinhamento das sequências de nucleotídeos contemplando as amostras geradas neste estudo com as demais do GenBank representativas do genotipo 19 da VP7 e do genótipo 31 da VP4, segue abaixo:

Alinhamento de um fragmento parcial de 794 nucleotídeos do gene codificador da VP7 de rotavírus aviário entre as amostras aqui geradas com outras previamente depositadas junto ao GenBank - São Paulo - 2013 (continua)

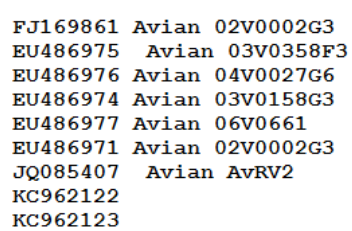

FJ169861 Avian 02V0002G3 EU486975 Avian 03V0358F3 EU486976 Avian 04V0027G6 EU486974 Avian 03V0158G3 EU486977 Avian 06V0661 EU486971 Avian 02V0002G3 JQ085407 Avian AvRV2 KC962122

KC962123

FJ169861 Avian 02V0002G3 EU486975 Avian 03V0358F3 EU486976 Avian 04V0027G6 EU486974 Avian 03V0158G3 EU486977 Avian 06v0661 EU486971 Avian 02V0002G3 JQ085407 Avian AvRV2 KC962122 KC962123

FJ169861 Avian 02V0002G3 EU486975 Avian 03V0358F3 EU486976 Avian 04V0027G6 EU486974 Avian 03V0158G3 EU486977 Avian 06v0661 EU486971 Avian 02V0002G3 JQ085407 Avian AvRV2 JQ085407 KC962122 KC962123

FJ169861 Avian 02V0002G3 U486975 Avian 03V0358F EU486976 Avian 04V0027G6 EU486974 Avian 03V0158G3 EU486977 Avian 06V0661 EU486971 Avian 02V0002G3 JQ085407 Avian AvRV2

KC962122

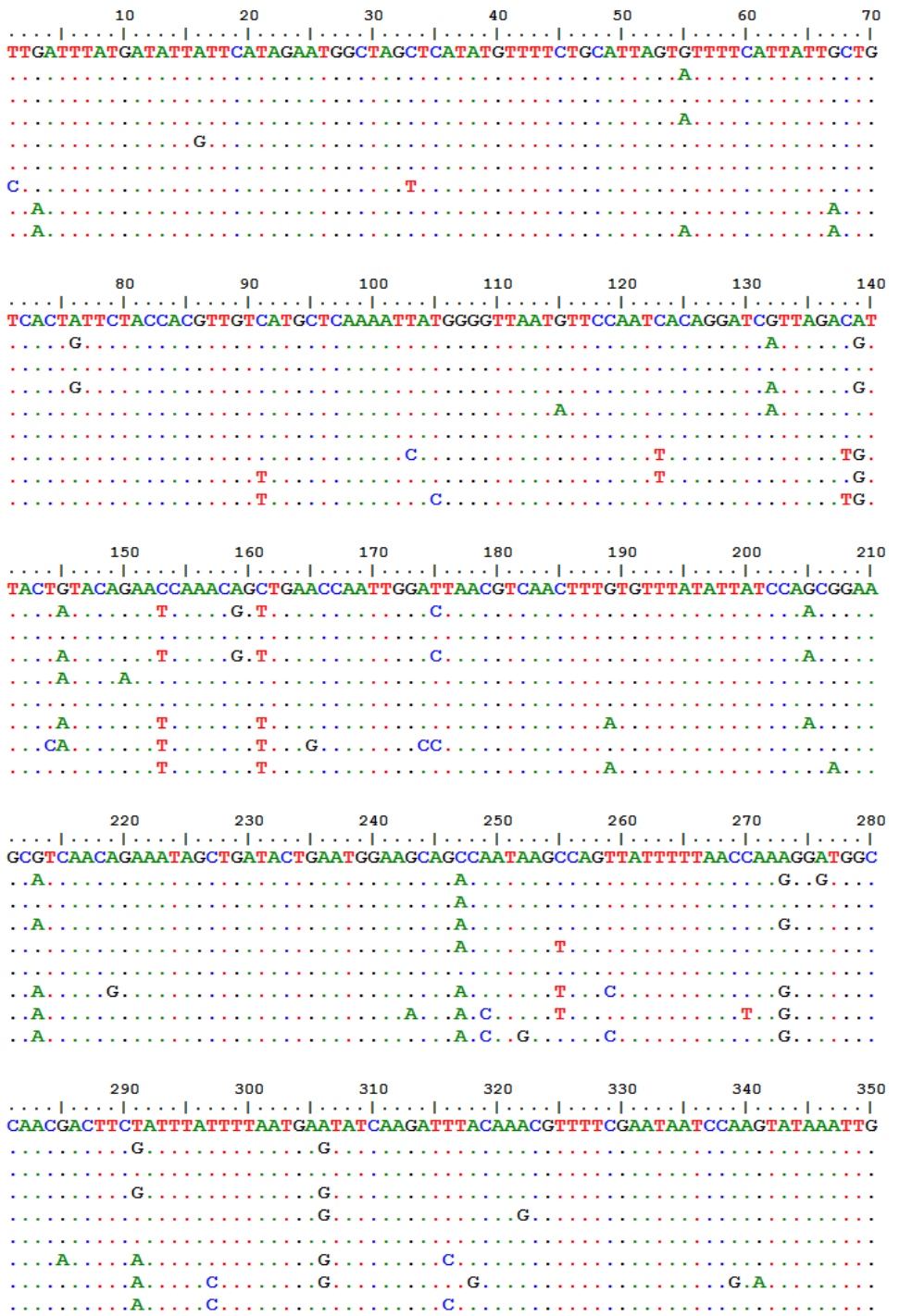

Fonte: Beserra (2013) 
Alinhamento de um fragmento parcial de 684 nucleotídeos do gene codificador da VP\& de rotavírus aviário entre as amostras aqui geradas com outras previamente depositadas junto ao GenBank - São Paulo - 2013

(conclusão)

FJ169861 Avian 02V0002G3 EU486975 Avian 03V0358F 3 EU486976 Avian 04V0027G6 EU486974 Avian 03V0158G EU486977 Avian 06V0661 EU486971 Avian 02V0002G3 JQ085407 Avian AvRV2 KC962122 KC962123

FJ169861 Avian 02V0002G3 EU486975 Avian 03V0358F 3 EU486975 Avian 03V0358F3 EU486976 Avian 04V0027G6 EU486974 Avian 03V0158G EU486977 Avian 06V0661 JQ085407 Avian AvRV2 KC962122

KC962123

FJ169861 Avian 02V0002G3 EU486975 Avian 03V0358F EU486976 Avian 04V0027G6 EU486974 Avian 03V0158G3 EU486977 Avian 06V0661 EU486971 Avian 02V0002G3 JQ085407 Avian AvRV2 KC962122

KC962123

FJ169861 Avian 02V0002G3 EU486975 Avian 03V0358F 3 EU486976 Avian 04V0027G6 EU486974 Avian 03v0158G3 EU486977 Avian 06v0661 EU486971 Avian 02V0002G3 JQ085407 Avian AvRV2

KC962122

KC962123

FJ169861 Avian 02V0002G3 EU486975 Avian 03V0358F EU486976 Avian 04V0027G6 EU486974 Avian 03V0158 EU486977 Avian 06V0661 EU486971 Avian 02V0002 KC962122

KC962122

FJ169861 Avian 02V0002G3 EU486975 Avian 03V0358F EU486976 Avian 04V0027G6 EU486974 Avian 03V0158G3 EU486977 Avian 06V0661 EU486971 Avian 02V0002G3 JQ085407 Avian AvRV2 KC962122 KC962123

FJ169861 Avian 02V0002G3 EU486975 Avian 03V0358F3 EU486976 Avian 04V0027G6 EU486974 Avian 03V0158G3 EU486977 Avian 06V0661

EU486971 Avian 02V0002G3 JQ085407 Avian AvRV2 KC962122

KC962123

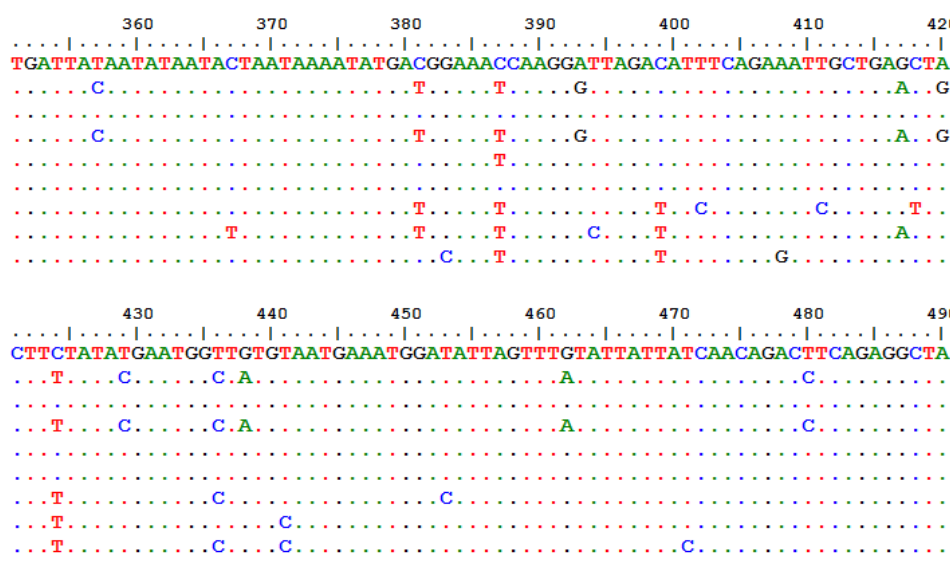

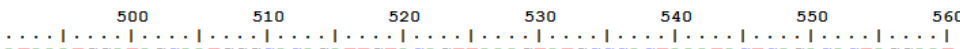
ATAAATGGATAGCAATGGGCACAGATTGTACAGTTAAAGTATGCCCACTAAATACTCAGACACTAGGAAT $\cdots$
$\cdots \cdots$
$n_{2}$ …

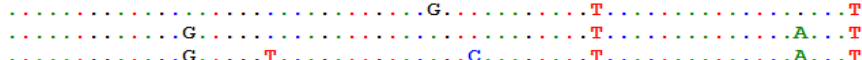

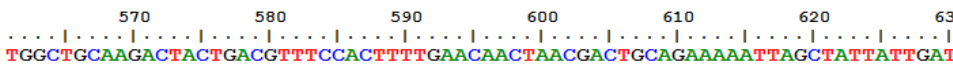

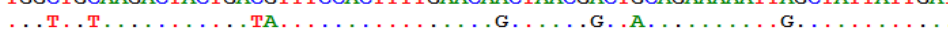
T. . ‥

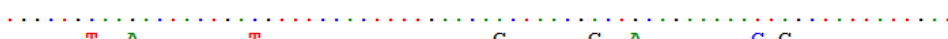

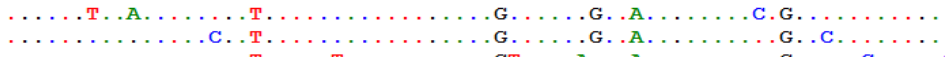

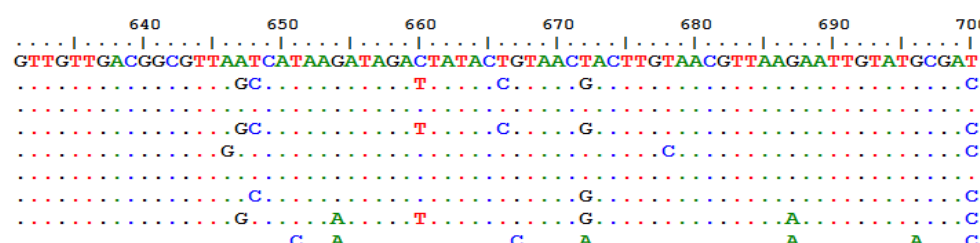

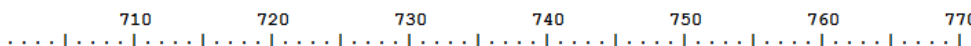

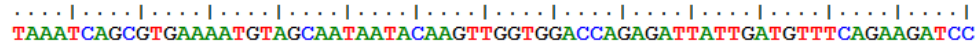

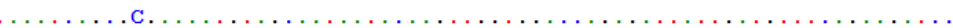

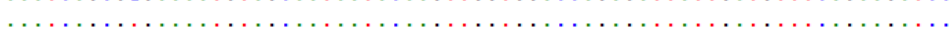

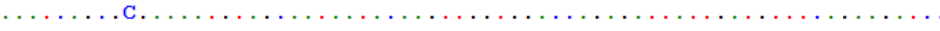
..............

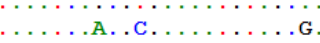
.C..............

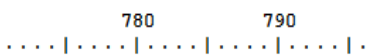
AATGGTTGTACCAAAAATGCAACGTG . . . . . . . . . . $\cdots \ldots \ldots \ldots \ldots \ldots \ldots \ldots \ldots \ldots \ldots \ldots$
$\cdots \ldots \ldots \ldots$ $\ldots \ldots \ldots \ldots \ldots \ldots \ldots \ldots \ldots$ . $\ldots \ldots$ G. W.G.G.G......G.G.C. .................C. 
Alinhamento de um fragmento parcial de 560 nucleotídeos do gene codificador da VP4 de rotavírus aviário entre as amostras aqui geradas com outras previamente depositadas junto ao GenBank - São Paulo - 2013

(continua)

EU486962 Avian Ch06v0661
KC962114
KC962115
KC962116
KC962117
KC962118
KC962119

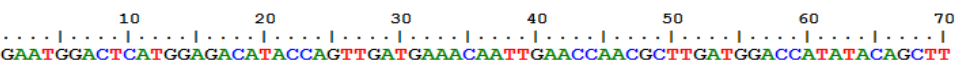

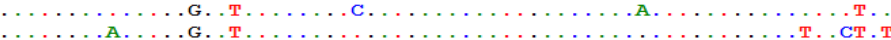

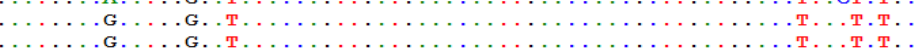

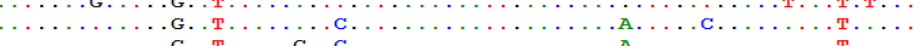

KC962119

$\begin{array}{ccccccc}80 & 90 & 100 & 110 & 120 & 130 & 140\end{array}$

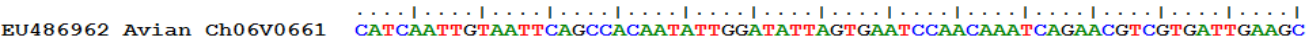
KC962114 KC962115

KC962116

KC962117

KC962118

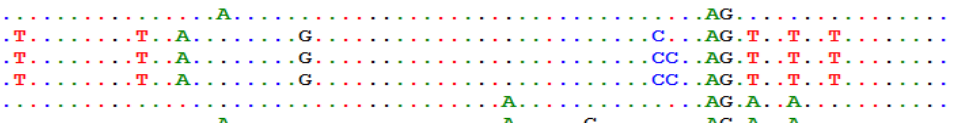

EU486962 Avian Ch06v0661 KC962114

KC962115

KC962116

KC962117

KC962119

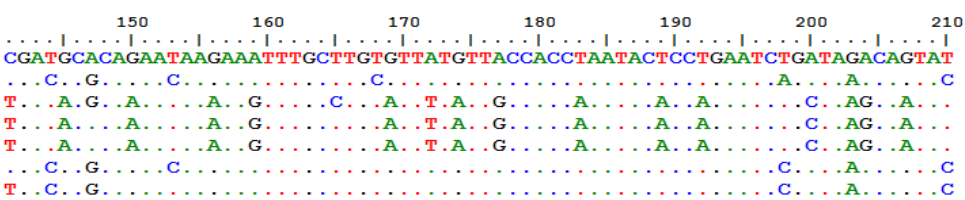

EU486962 Avian Ch06v0661 KC962114

KC962115

KC962116

KC962117

KC962118

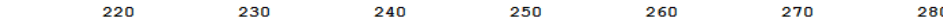

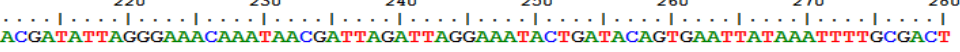

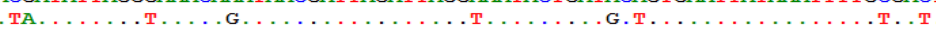

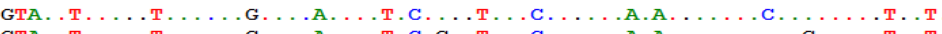

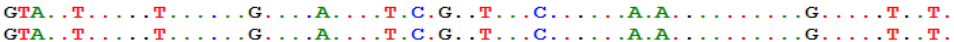
та.

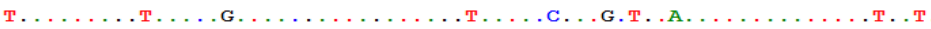
EU486962 Avian Ch06v0661

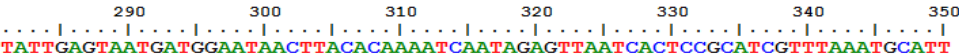
KC962115

KC962115

KC962117

KC962117

KC962119

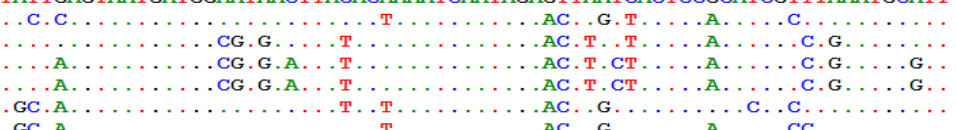

EU486962 Avian Ch06v0661

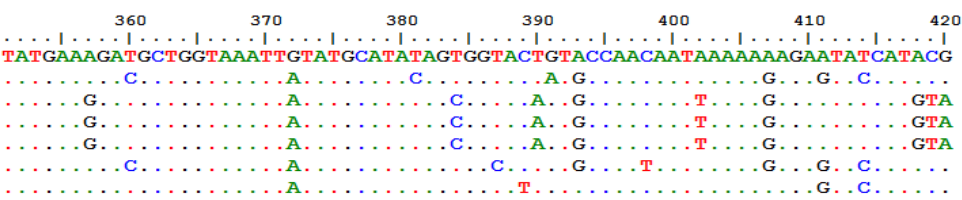

EU486962 Avian Ch06v0661 KC962114

KC962115

KC962116

KC962117

KC962118

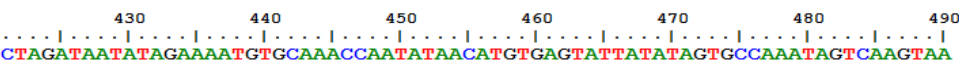

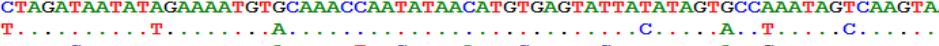

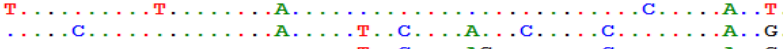
…

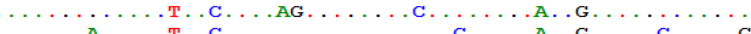
C - Tho

EU486962 Avian Ch06v0661 KC962114

KC962115

KC962116

KC962117

KC962118

KC962119

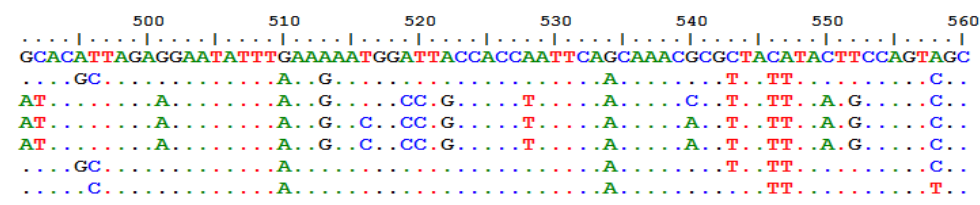

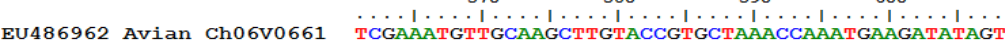

KC962114

KC962115

KC962116

KC962117

KC962118

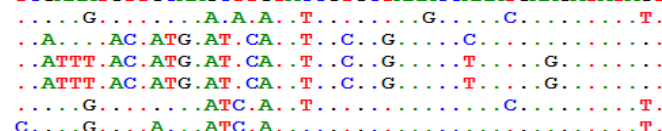

Fonte: Beserra (2013) 
O alinhamento de um fragmento parcial de 664 nucleotídeos das sequências de nucleotídeos contemplando as amostras de rotavírus aviáriodo grupo D - VP6 - geradas neste estudo com as demais do GenBank representativas dos demais grupos definidos, segue abaixo (conclusão)

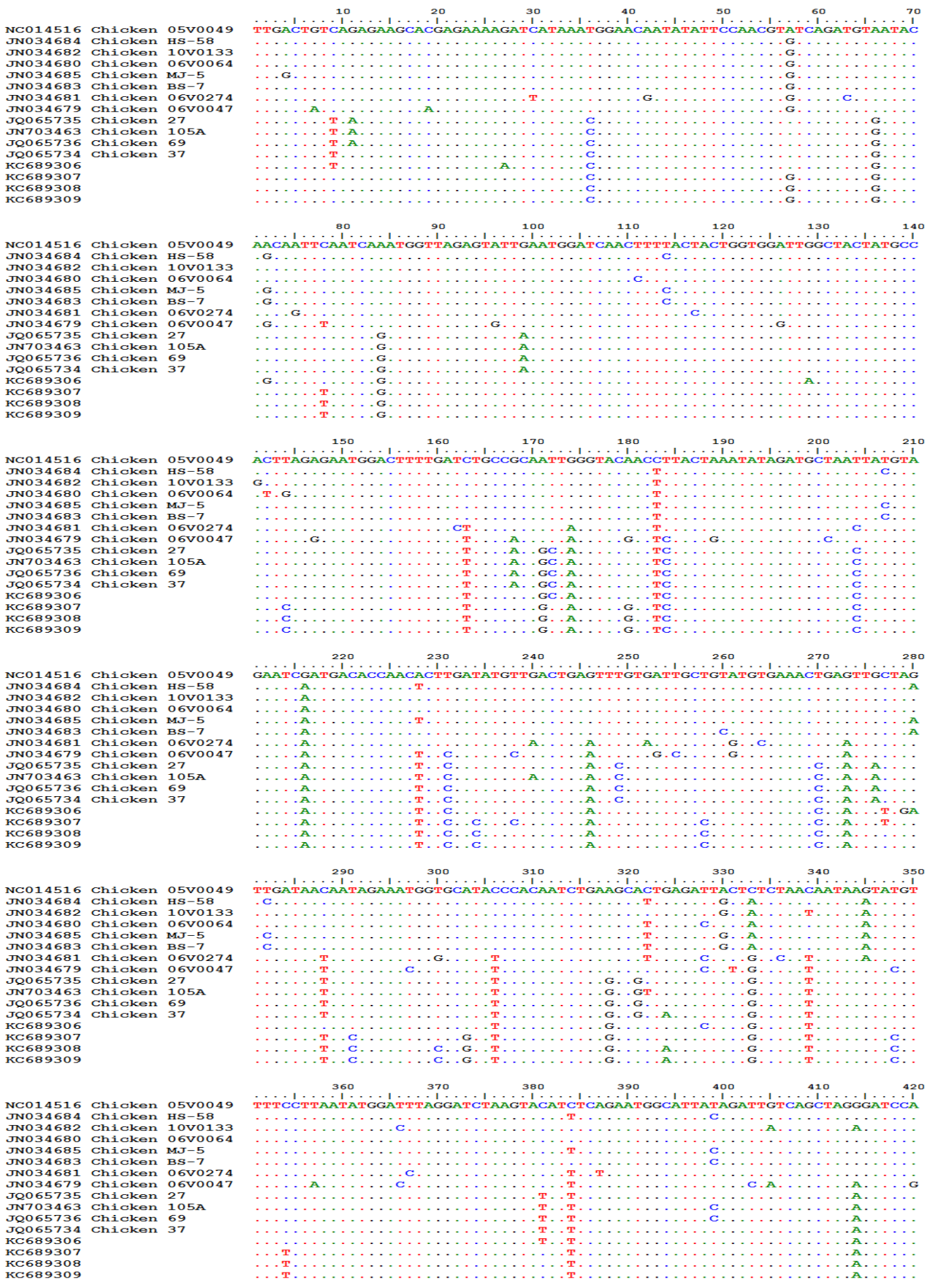

Fonte: Beserra (2013) 
O alinhamento das sequências de nucleotídeos contemplando as amostras de rotavírus aviário do grupo D - VP6 - geradas neste estudo com as demais do GenBank representativas dos demais grupos definidos, segue abaixo (conclusão) - São Paulo - 2013

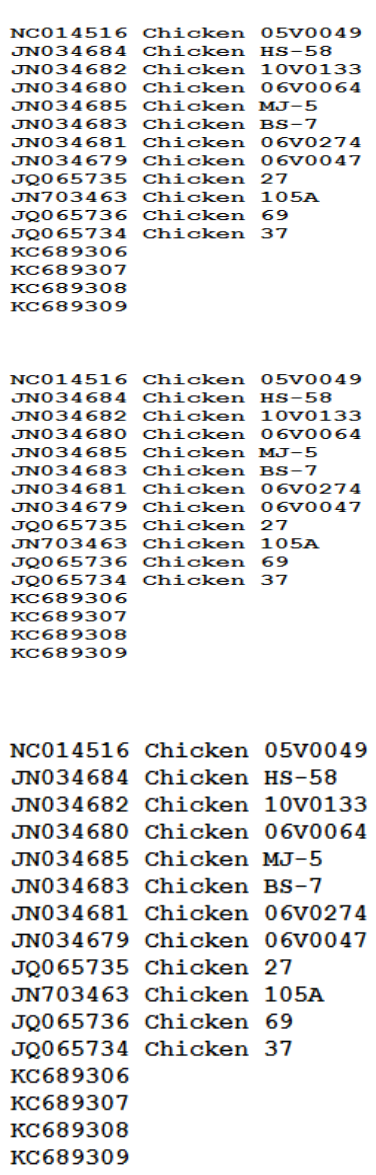

NC014516 Chicken 05v0049 JN034684 Chicken HS-58

JN034682 Chicken 10V0133

JN034680 Chicken 06V0064

JN034685 Chicken MJ-5

JN034683 Chicken BS-7

JN034681 Chicken 06V0274

JN034679 Chicken 06V0047

JQ065735 Chicken 27

JN703463 Chicken 105A

JQ065736 Chicken 69

JQ065734 Chicken 37

KC689306

KC689307

KC689308

KC689309

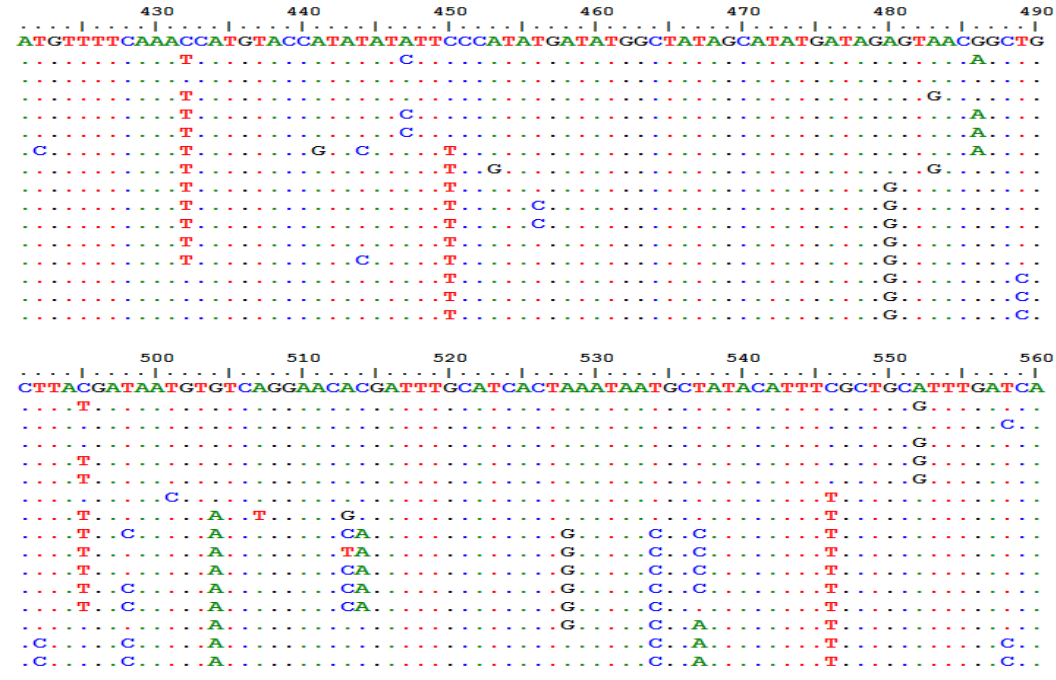

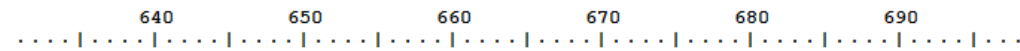

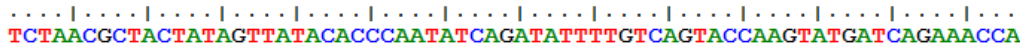

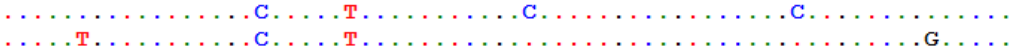

.

…

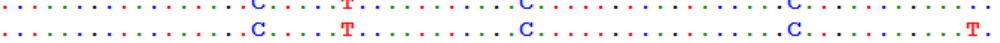

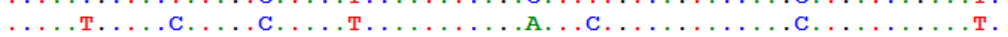

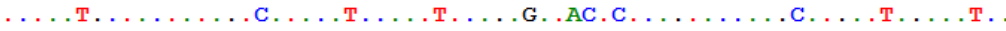

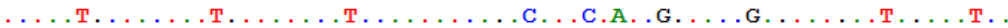

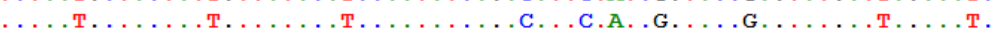

. . . . . . . . . . . . . . . . . . . . . . . . .

... . . . . . . . . . . . . . . . . . . . . . . . .

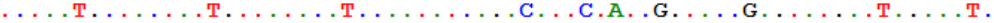

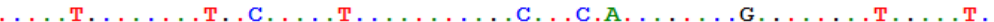

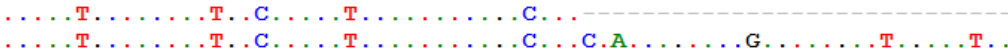

Fonte: Beserra (2013) 


\section{APÊNDICE C}

O alinhamento das sequências parciais convertidas em aminoácidos contemplando as amostras geradas neste estudo com as demais do GenBank representativas do genotipo 19 da VP7 e do genótipo 31 da VP4, segue abaixo:

Alinhamento de um fragmento parcial de 264 aminoácidos do gene codificador da VP7 de rotavírus aviário entre as amostras aqui geradas com outras previamente depositadas junto ao GenBank - São Paulo - 2013

FJ169861 Avian 02V0002G3 JQ085407 Avian AvRV2 EU486975 Avian 03V0358F3 EU486976 Avian 04V0027G6 EU486974 Avian 03V0158G3 EU486977 Avian 06V0661 EU486971 Avian 02V0002G3 KC962122 KC962123

FJ169861 Avian 02V0002G3 JQ085407 Avian AvRV2 EU486975 Avian 03V0358F3 EU486976 Avian 04V0027G6 EU486974 Avian 03V0158G3 EU486977 Avian 06V0661 EU486971 Avian 02V0002G3 KC962122 KC962123

FJ169861 Avian 02V0002G3 JQ085407 Avian AvRV2 EU486975 Avian 03V0358F3 EU486976 Avian 04V0027G6 EU486974 Avian 03V0158G3 EU486977 Avian 06V0661 EU486971 Avian 02V0002G3 KC962122 KC962123

FJ169861 Avian 02V0002G3 JQ085407 Avian AvRV2 EU486975 Avian 03V0358F3 EU486976 Avian 04V0027G6 EU486974 Avian 03V0158G3 EU486977 Avian 06V0661 EU486971 Avian 02V0002G3 KC962122 KC962123

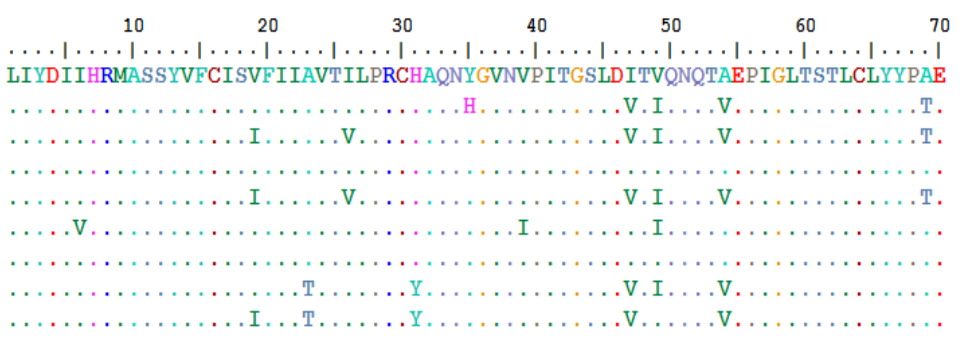

80
80 $\quad 100 \quad 110 \quad 120 \quad 130 \quad 140$ ASTEIADTEWKQPISQLFLTKGWPTTSIYFNEYQDLQTF SNNPS SNCDYNIILIKYDGNQGLDISEIAEL ........... T. .

.......... T.

.........

T.

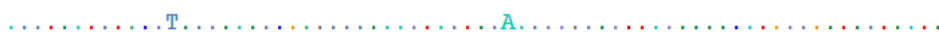

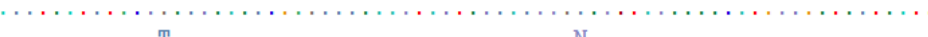

…

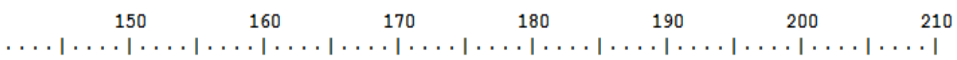
LLYEWLCNEMDISLYYYQQTSEANKWIAMGTDCTVKVCPLNTQTLGIGCKTTDVSTFELTTAEKLAIID

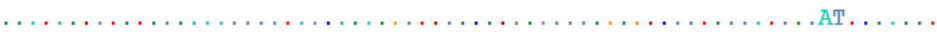

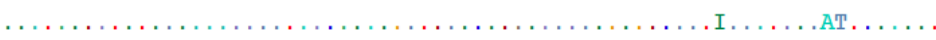

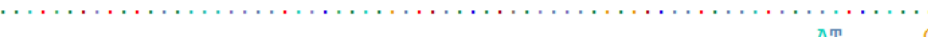

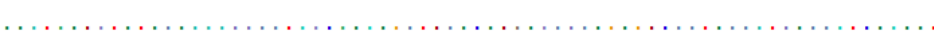

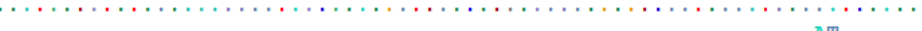

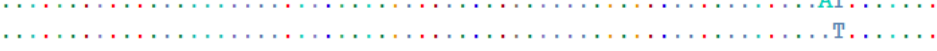

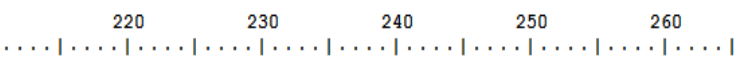

VVDGVNHKIDYTVTTCNVKNCMRLNQRENVAIIQVGGPEIIDVSED PMVVPKMQR

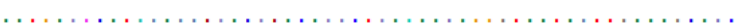

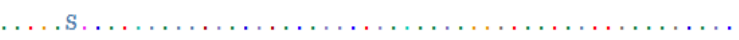

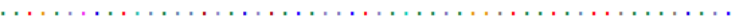

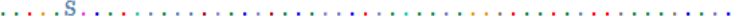

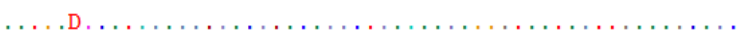

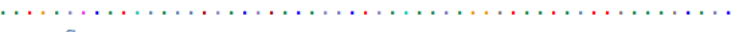

$\ldots \ldots$ S. 
Alinhamento de um fragmento parcial de 202 aminoácidos do gene codificador da VP4 de rotavírus aviário entre as amostras aqui geradas com outras previamente depositadas junto ao GenBank - São Paulo - 2013.

EU486962 Avian Ch06v0661
KC962114
KC962115
KC962116
KC962117
KC962118
KC962119

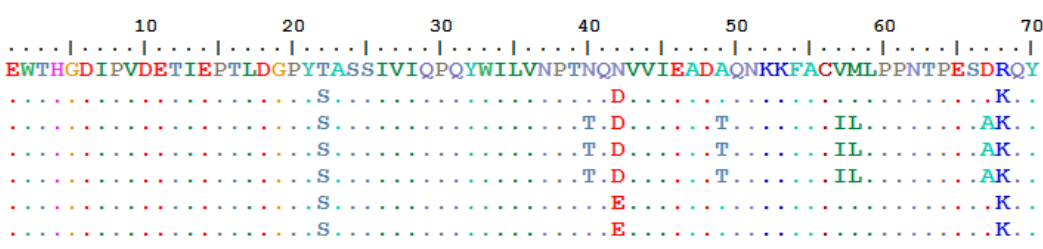

80

$90 \quad 100 \quad 110 \quad 120 \quad 130 \quad 140$

EU486962 Avian Ch06V0661 TILGKITIRLGNTDVNYKFCDLLSNDGITYTKSIELITPHRLNAFMKDAGKLYAYSGTVPTIKKEYHT

KC962114

KC962115

KC962116

KC962117

KC962118

KC962119

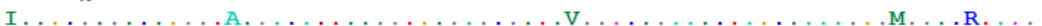

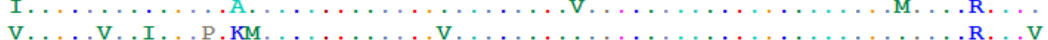

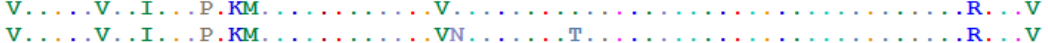

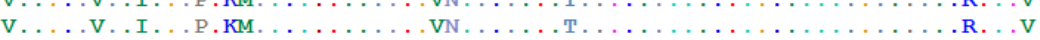

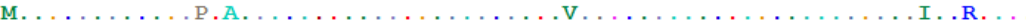

150

160

$170 \quad 180$

190

200

EU486962 Avian Ch06v0661 LDNIENVQTNITCEYYIVPNSQVSTLEEYLKNGLPPIQQTRYILPVARNVASLYRAKPNEDI

KC962114

KC962115

KC962116

KC962117

KC962118

KC962119

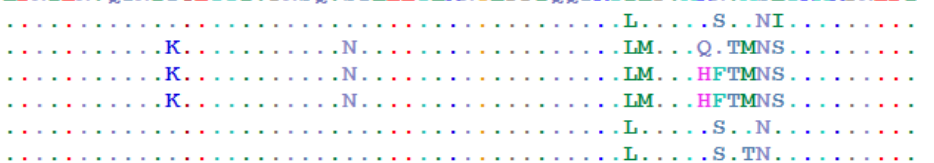

Fonte: Beserra (2013) 
O alinhamento das sequências convertidas em aminoácidos contemplando as amostras de rotavírus do grupo D geradas neste estudo com as demais do GenBank representativas de rotavírus D em aves segue abaixo - São Paulo - 2013

$\begin{array}{ll}\text { NC014516 } & \text { Chicken } 05 \mathrm{~V} 0049 \\ \text { JN034684 } & \text { Chicken HS-58 } \\ \text { JN034682 } & 10 \mathrm{~V} 0133 \\ \text { JN034680 } & 06 \mathrm{~V} 0064 \\ \text { JN034685 } & \text { MJ-5 } \\ \text { JN034683 } & \text { BS-7 } \\ \text { JN034681 } & 06 \mathrm{~V} 0274 \\ \text { JN034679 } & 06 \mathrm{~V} 0047 \\ \text { JQ065735 } & 27 \\ \text { JN703463 } & 105 \mathrm{~A} \\ \text { JQ065736 } & 69 \\ \text { JQ065734 } & 37 \\ \text { KC689306 } & \\ \text { KC689307 } & \\ \text { KC689308 } & \\ \text { KC689309 } & \end{array}$

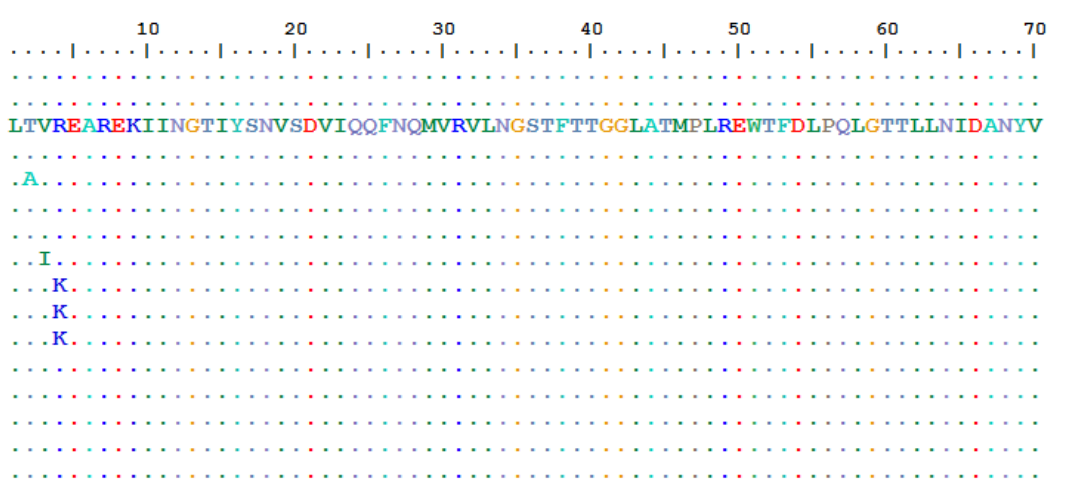

$\begin{array}{ll}\text { NC014516 } & \text { Chicken } 05 \mathrm{~V} 0049 \\ \text { JN034684 } & \text { Chicken HS-58 } \\ \text { JN034682 } & \text { 10V0133 } \\ \text { JN034680 } & 06 \mathrm{~V} 0064 \\ \text { JN034685 } & \text { MJ-5 } \\ \text { JN034683 } & \text { BS-7 } \\ \text { JN034681 } & 06 \mathrm{~V} 0274 \\ \text { JN034679 } & 06 \mathrm{~V} 0047 \\ \text { JQ065735 } & 27 \\ \text { JN703463 } & 105 \mathrm{~A} \\ \text { JQ065736 } & 69 \\ \text { JQ065734 } & 37 \\ \text { KC689306 } & \\ \text { KC689307 } & \\ \text { KC689308 } & \\ \text { KC689309 } & \end{array}$

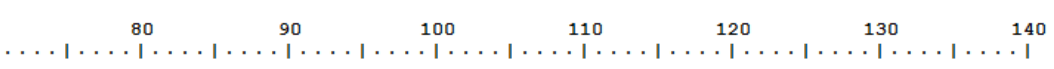

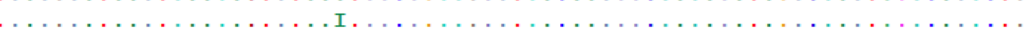

ESMTPTLDMLTE FVIAVCETELLVDNNR GAYPQSEALRLLSNNKYVFLNMDLGSKYISEWHYRLSARDP

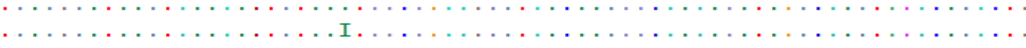

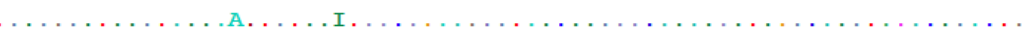

.

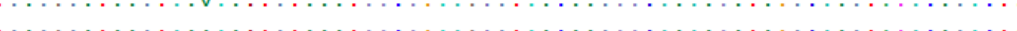

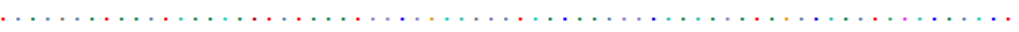

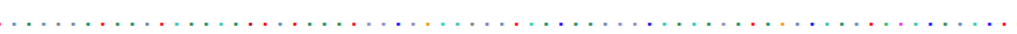

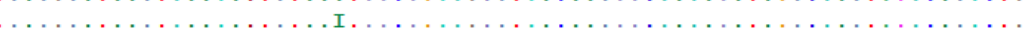

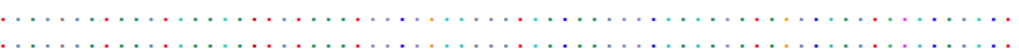

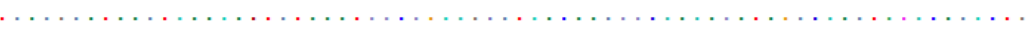

NC014516 Chicken 05V0049 JN034684 Chicken HS-58 JN034682 10V0133

JN034680 06V0064

JN034685 MJ-5

JN034683 BS-7

JN034681 $06 \mathrm{~V} 0274$

JN034679 $06 \mathrm{~V} 0047$

JQ065735 27

JN703463 105A

JQ065736 69

JQ065734 37

KC689306

KC689307

KC689308

KC689309

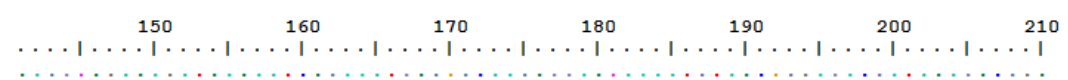

MF SNHVPYIFPYDMAIAYDRVTAAYDNVSGTRFASLNNAIHFAAFD D FVRGQPANAROFEYLYNLRTPV

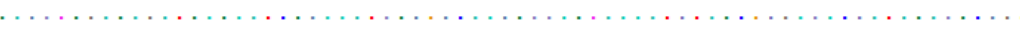

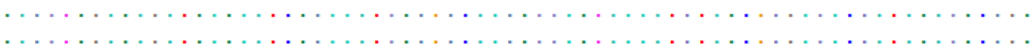

т.

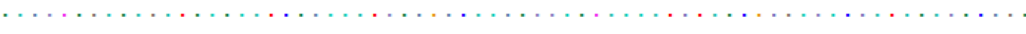

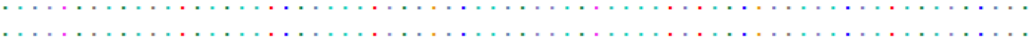

.

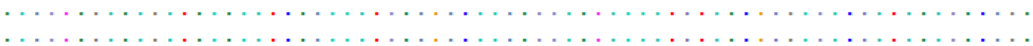

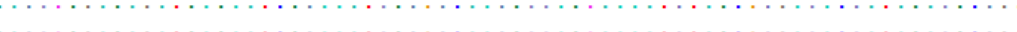

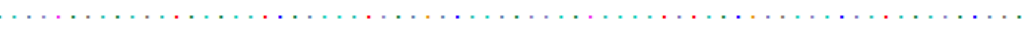

220

NC014516 Chicken 05V0049 JN034684 Chicken HS-58 JN034682 10V0133

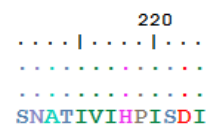

Fonte: Beserra (2013) 


\section{APÊNDICE D}

Apêndice D - Valores de similaridade nucleotídica e de aminoácidos da região consensual das sequências de rotavírus do grupo A geradas neste estudo (USPARV05 e USPARV06) frente às demais representativas do genotipo G19 de VP7 depositadas no GenBank. As áreas em branco representam as identidades nucleotídicas, e as cinzas, as identidades de aminoácidos São Paulo - 2013

\begin{tabular}{|c|c|c|c|c|c|c|c|c|c|}
\hline & FJ169861 & JQ085407 & EU486975 & EU486976 & EU486974 & EU486977 & EU486971 & KC962122 & KC962123 \\
\hline FJ169861 & ID & 0,969 & 0,958 & 0,996 & 0,958 & 0,977 & 1 & 0,962 & 0,958 \\
\hline JQ085407 & 0,938 & ID & 0,981 & 0,973 & 0,981 & 0,962 & 0,969 & 0,977 & 0,958 \\
\hline EU486975 & 0,939 & 0,942 & ID & 0,962 & 0,992 & 0,954 & 0,958 & 0,973 & 0,954 \\
\hline EU486976 & 0,997 & 0,938 & 0,942 & ID & 0,962 & 0,981 & 0,996 & 0,966 & 0,962 \\
\hline EU486974 & 0,94 & 0,943 & 0,996 & 0,943 & ID & 0,954 & 0,958 & 0,973 & 0,954 \\
\hline EU486977 & 0,977 & 0,933 & 0,937 & 0,979 & 0,938 & ID & 0,977 & 0,958 & 0,943 \\
\hline EU486971 & 1 & 0,938 & 0,939 & 0,997 & 0,94 & 0,977 & ID & 0,962 & 0,958 \\
\hline КС962122 & 0,928 & 0,937 & 0,932 & 0,928 & 0,933 & 0,925 & 0,928 & ID & 0,966 \\
\hline KC962123 & 9,929 & 0,934 & 0,919 & 0,932 & 0,92 & 0,919 & 0,929 & 0,937 & ID \\
\hline
\end{tabular}

Fonte: Beserra (2013) 


\section{APÊNDICE E}

Apêndice E - Valores de similaridade nucleotídica e de aminoácidos da região consensual das sequências de rotavírus do grupo A geradas neste estudo (USPARV01 a USPARV06) frente às demais representativas do genotipo $\mathrm{P}[31]$ de VP4 depositadas no GenBank. As áreas em branco representam as identidades nucleotídicas, e as cinzas, as identidades de aminoácidos São Paulo - 2013

\begin{tabular}{|l|r|r|r|r|r|r|r|}
\hline & EU486962 & KC962114 & KC962115 & KC962116 & KC962117 & KC962118 & KC962119 \\
\hline EU486962 & ID & 0,94 & 0,871 & 0,861 & 0,861 & 0,94 & 0,945 \\
\hline KC962114 & 0,893 & ID & 0,886 & 0,881 & 0,881 & 0,97 & 0,965 \\
\hline KC962115 & 0,815 & 0,815 & ID & 0,99 & 0,99 & 0,886 & 0,876 \\
\hline KC962116 & 0,81 & 0,805 & 0,967 & ID & 1 & 0,881 & 0,871 \\
\hline KC962117 & 0,81 & 0,805 & 0,967 & 1 & ID & 0,881 & 0,871 \\
\hline KC962118 & 0,883 & 0,944 & 0,81 & 0,802 & 0,802 & ID & 0,975 \\
\hline KC962119 & 0,889 & 0,935 & 0,812 & 0,804 & 0,804 & 0,952 & ID \\
\hline
\end{tabular}

Fonte: Beserra (2013) 


\section{APÊNDICE F}

Apêndice F - Valores de similaridade nucleotídica e de aminoácidos da região consensual das sequências de rotavírus do grupo D geradas neste estudo (AVRVBR01 a AVRVBR04) frente às demais representativas também do grupo D (VP6) no GenBank. As áreas em branco representam as identidades nucleotídicas, e as cinzas, as identidades de aminoácidos - São Paulo - 2013

\begin{tabular}{|c|c|c|c|c|c|c|c|c|c|c|c|c|c|c|c|c|}
\hline & $\begin{array}{c}\mathrm{NC} 0145 \\
16\end{array}$ & $\begin{array}{c}\text { JN0346 } \\
84\end{array}$ & $\begin{array}{c}\mathrm{JN} 0346 \\
82\end{array}$ & $\begin{array}{c}\text { JN0346 } \\
80\end{array}$ & $\begin{array}{c}\text { JN0346 } \\
85\end{array}$ & $\begin{array}{c}\mathrm{JN} 0346 \\
83\end{array}$ & $\begin{array}{c}\text { JN0346 } \\
81\end{array}$ & $\begin{array}{c}\text { JN0346 } \\
79\end{array}$ & $\begin{array}{c}\text { JQ0657 } \\
35\end{array}$ & $\begin{array}{c}\text { JN7034 } \\
63\end{array}$ & $\begin{array}{c}\text { JQ0657 } \\
36\end{array}$ & $\begin{array}{c}\mathrm{JQ} 0657 \\
34\end{array}$ & $\begin{array}{c}\text { KC6893 } \\
06\end{array}$ & $\begin{array}{c}\mathrm{KC} 6893 \\
07\end{array}$ & $\begin{array}{c}\text { KC6893 } \\
08\end{array}$ & $\begin{array}{c}\text { KC6893 } \\
09\end{array}$ \\
\hline $\begin{array}{c}\text { NC0145 } \\
16 \\
\end{array}$ & ID & 0,995 & 1 & 1 & 0,991 & 0,991 & 0,991 & 0,986 & 0,995 & 0,995 & 0,995 & 1 & 0,995 & 1 & 1 & 1 \\
\hline $\begin{array}{c}\mathrm{JN} 0346 \\
84 \\
\end{array}$ & 0,961 & ID & 0,995 & 0,995 & 0,995 & 0,995 & 0,986 & 0,982 & 0,991 & 0,991 & 0,991 & 0,995 & 1 & 0,995 & 0,995 & 0,995 \\
\hline $\begin{array}{c}\text { JN0346 } \\
82\end{array}$ & 0,976 & 0,961 & ID & 1 & 0,991 & 0,991 & 0,991 & 0,986 & 0,995 & 0,995 & 0,995 & 1 & 0,995 & 1 & 1 & 1 \\
\hline $\begin{array}{c}\text { JN0346 } \\
80\end{array}$ & 0,974 & 0,971 & 0,971 & ID & 0,991 & 0,991 & 0,991 & 0,986 & 0,995 & 0,995 & 0,995 & 1 & 0,995 & 1 & 1 & 1 \\
\hline $\begin{array}{c}\mathrm{JN} 0346 \\
85\end{array}$ & 0,959 & 0,998 & 0,959 & 0,97 & $\overline{I D}$ & 0,991 & 0,982 & 0,977 & 0,986 & 0,986 & 0,986 & 0,991 & 0,995 & 0,991 & 0,991 & 0,991 \\
\hline $\begin{array}{c}\text { JN0346 } \\
83\end{array}$ & 0,962 & 0,992 & 0,962 & 0,973 & 0,991 & ID & 0,982 & 0,977 & 0,986 & 0,986 & 0,986 & 0,991 & 0,995 & 0,991 & 0,991 & 0,991 \\
\hline $\begin{array}{c}\text { JN0346 } \\
81\end{array}$ & 0,92 & 0,917 & 0,922 & 0,928 & 0,916 & 0,919 & ID & 0,986 & 0,986 & 0,986 & 0,986 & 0,991 & 0,986 & 0,991 & 0,991 & 0,991 \\
\hline $\begin{array}{c}\text { JN0346 } \\
79\end{array}$ & 0,901 & 0,901 & 0,908 & 0,905 & 0,899 & 0,896 & 0,901 & ID & 0,982 & 0,982 & 0,982 & 0,986 & 0,982 & $\begin{array}{l}0,986 \\
\end{array}$ & 0,986 & 0,986 \\
\hline $\begin{array}{c}\text { JQ0657 } \\
35\end{array}$ & 0,91 & 0,899 & 0,905 & 0,904 & 0,898 & 0,898 & 0,901 & 0,907 & ID & 1 & 1 & 0,995 & 0,991 & 0,995 & 0,995 & 0,995 \\
\hline $\begin{array}{c}\text { JN7034 } \\
63\end{array}$ & 0,907 & 0,902 & 0,902 & 0,904 & 0,901 & 0,898 & 0,901 & 0,904 & 0,989 & ID & 1 & 0,995 & 0,991 & 0,995 & 0,995 & 0,995 \\
\hline $\begin{array}{c}\text { JQ0657 } \\
36\end{array}$ & 0,91 & 0,902 & 0,905 & 0,904 & 0,901 & 0,898 & 0,898 & 0,907 & 0,992 & 0,994 & ID & 0,995 & 0,991 & 0,995 & 0,995 & 0,995 \\
\hline $\begin{array}{c}\text { JQ0657 } \\
34\end{array}$ & 0,908 & 0,898 & 0,904 & 0,902 & 0,896 & 0,896 & 0,902 & 0,908 & 0,995 & 0,985 & 0,988 & ID & 0,995 & 1 & 1 & 1 \\
\hline $\begin{array}{c}\text { KC6893 } \\
06\end{array}$ & 0,914 & 0,91 & 0,91 & 0,911 & $\begin{array}{l}0,908 \\
\end{array}$ & 0,908 & 0,905 & 0,905 & 0,968 & 0,958 & 0,961 & 0,967 & ID & 0,995 & 0,995 & 0,995 \\
\hline $\begin{array}{c}\text { KC6893 } \\
07\end{array}$ & 0,917 & 0,907 & 0,919 & 0,916 & 0,905 & 0,905 & 0,908 & 0,916 & 0,9946 & 0,94 & 0,941 & 0,944 & 0,949 & ID & & 1 \\
\hline $\begin{array}{c}\text { KC6893 } \\
08\end{array}$ & 0,913 & 0,902 & 0,917 & 0,911 & 0,901 & 0,901 & 0,905 & 0,908 & 0,941 & 0,932 & 0,934 & 0,943 & 0,944 & 0,986 & ID & 1 \\
\hline $\begin{array}{c}\text { KC6893 } \\
09\end{array}$ & 0,913 & 0,902 & 0,92 & 0,911 & 0,901 & 0,901 & 0,905 & 0,908 & 0,941 & 0,932 & 0,934 & 0,943 & 0,941 & 0,986 & 0,997 & ID \\
\hline
\end{tabular}

Fonte: Beserra (2013) 
